\title{
BRYOPHYTE FLORA OF ALTAI MOUNTAINS. VIII. BRACHYTHECIACEAE
}

\author{
МОХООБРАЗНЫЕ АЛТАЯ. VIII. ВRАСНYТНЕСIAСЕАЕ \\ MiCHAEL S. IGNATOV ${ }^{1}$ \\ МИХАИЛ С. ИГНАТОВ ${ }^{1}$
}

Abstract

\begin{abstract}
The family Brachytheciaceae in Altai is represented by 8 genera and 33 species: Brachythecium buchananii, B. cirrosum, B. collinum, B. complanatum, B. dovrense, $B$. erythrorrhizon ssp. asiaticum ssp. nov., B. falcatulum, B. glaciale, B. latifolium, B. mildeanum, $B$. oedipodium, $B$. ornellanum, $B$. plumosum, $B$. populeum, $B$. reflexum, $B$. rivulare, $B$. rotaeanum, B. rutabulum, B. salebrosum, B. starkei, B. trachypodium, B. turgidum, B. velutinum, Bryhnia novae-angliae, Cirriphyllum piliferum,Eurhynchium altaicum sp.nov.,E. angustirete, E. hians, E. pulchellum, Homalothecium philippeanum, Myuroclada maximowiczii, Platyhypnidium riparioides, Scleropodiopsis laxiretis gen. et sp.nov. For each species descriptions, illustrations, and distribution and habitat preferences in Altai are provided
\end{abstract}

Резюме

Семейство Brachytheciaceae на Алтае представлено 8 родами и 33 видами: Brachythecium buchananii, B. cirrosum, B. collinum, B. complanatum, B. dovrense, B. erythrorrhizon ssp. asiaticum ssp. nov., B. falcatulum, B. glaciale, B. latifolium, B. mildeanum, $B$. oedipodium, $B$. ornellanum, $B$. plumosum, B. populeum, $B$. reflexum, $B$. rivulare, $B$. rotaeanum, B. rutabulum, B. salebrosum, B. starkei, B. trachypodium, B. turgidum, B. velutinum, Bryhnia novae-angliae,Cirriphyllum piliferum,Eurhynchium altaicum sp.nov.,E. angustirete, E. hians, E. pulchellum, Homalothecium philippeanum, Myuroclada maximowiczii, Platyhypnidium riparioides, Scleropodiopsis laxiretis gen. et sp. nov. Для каждого вида дано описание, иллюстрации, описано его распространение и характерные местообитания на Алтае.

\section{INTRODUCTION}

This paper continues the series started in the third volume of Arctoa. For the explanation of specimen citations and review of nature conditions in this area see Ignatov (1994).

The Brachytheciaceae is well delimited from other pleurocarpous families except Meteoriaceae (Ignatov, 1998). It includes pleurocarpous mosses with: (1) a specific arrangement of pseudoparaphyllia around the branch primordia, with the first pseudoparaphyllium pointed downward, and the second and the third developing at about $120^{\circ}$ from the first one (Figs. 2-4,6, 8, 9, 11-13, etc., see also Ignatov, 1998); (2) paraphyllia absent; (3) leaves with more or less developed costa, rarely (in tropical genera) with costa very short to absent; (4) laminal cells smooth, rarely prorate, but never papillose, typically elongate (2)4-10(15):1 ; (5) perichaetial leaves usually without or with weak costa and non-plicate (an exception is Brachythecium reflexum with costa reaching to nearly the apex); (5) seta long, with mature capsule raised high above perichaetium; (6) peristome double, endostome complete to sometimes reduced, and then with cilia short to absent and very rarely segments absent; (7) exostome teeth usually deeply brownish or reddish in lower part or throughout.

Plants of the Brachytheciaceae in Altai vary from small (Brachythecium collinum) to robust (B. turgidum, Eurhynchium angustirete), growing on soil and rocks, humus, decaying wood, tree bases, and relatively rarely high on tree trunks (Brachythecium rotaeanum, B. рориleum), sometimes submerged in running water (Platyhypnidium riparioides). Branching is principally pinnate, but all species also devel-

1 - Main Botanical Garden of Russian Academy of Sciences, Botanicheskaya 4, Moscow 127276 Russia - Poсcия 127276 Москва, Ботаническая 4, Главный ботанический сад РАН 

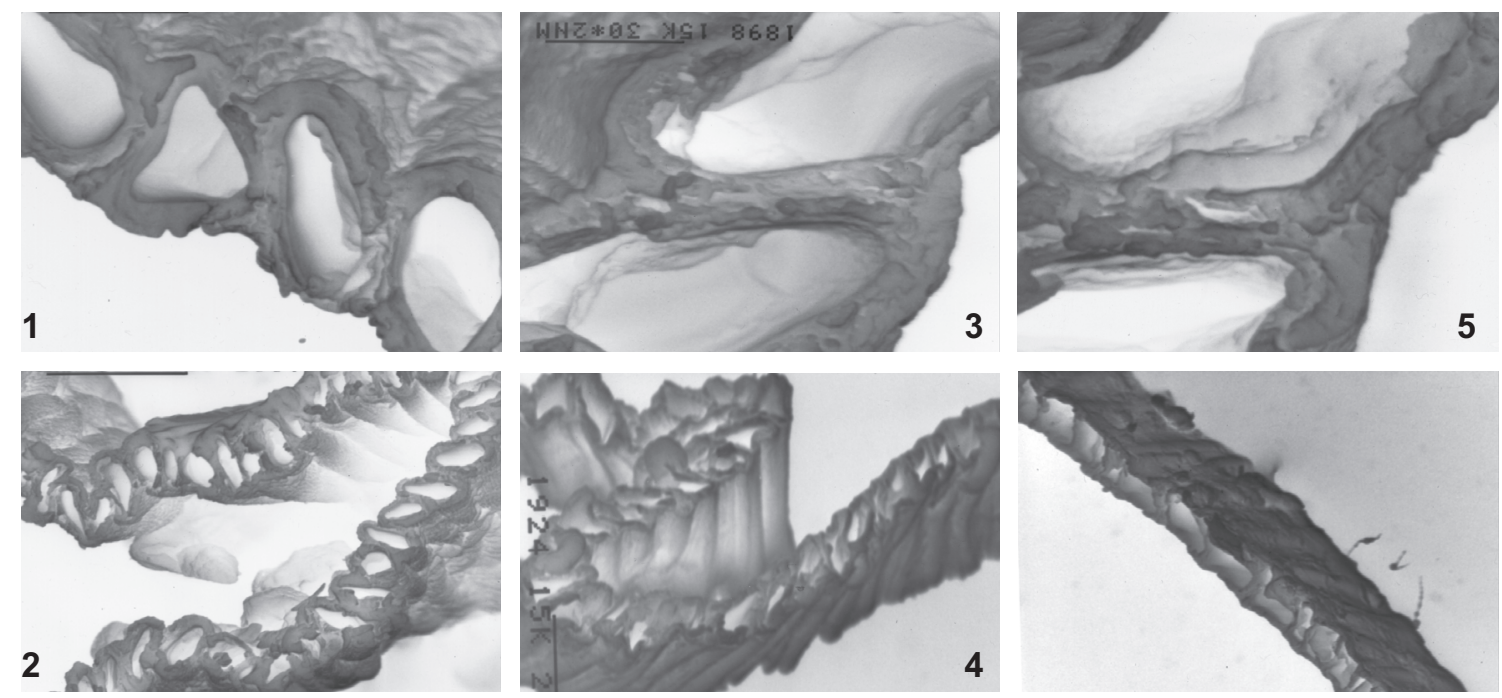

Fig. 1. Transverse sections of stem leaves: 1-2 - Homalothecium philippeanum (Spruce) B.S.G. (from Ignatov 21/ 32a); 3-4 - Brachythecium salebrosum (Web. et Mohr) B. S. G. (from Ignatov 0/1646); 5-6 - Platyhypnidium riparioides (Hedw.) Dix. (from Ignatov 1/35): 1 - 7500x; $2-1850 x ; 3-7500 x ; 4-1400 x ; 5-9000 x ; 6-1200 x$.

op sympodial branches, i. e. branches which continue their growth and branching further (branch initials are always present on both stem and branches). In some species (Brachythecium rivulare, Bryhnia novae-angliae) sympodial branches are numerous and usually orthotropous, resulting in a subdendroid habit of the plants. In Myuroclada maximowiczii, Platyhypnidium riparioides,Homalothecium philippeanum, and some phenotypes of Brachythecium plumosum the branching is irregular and the "branches" are indistinguishable from the "stem" (cf. Figs. 2, 36, 42). In some species (i. e., Eurhynchium hians, E. pulchellum) the stems are partly unbranched, with much smaller leaves and such creeping stoloniferous zones alternate with normal pinnately branched zones. The differentiation of leaves within one plant may show several paterns: (1) In most species of Brachythecium, Eurhynchium pulchellum, E. angustirete, Cirriphyllum, etc., the branch leaves are smaller,narrower, more strongly serrate, and the costal spine longer on abaxial surface, and the laminal cells are narrower than in the stem leaves. Leaves on sympodial branches are intermediate in their characters between stem and branch leaves. (2) In plants with primarily sympodial branching (Bryhnia, Myuroclada) the leaves are differentiated within single shoots, but the differentiation between stem and branch leaves is indistinct. In Myuroclada the leaves differ mainly in size, whereas in Bryhnia they differ also in shape. (3) In Eurhynchium hians the stem leaves are small in un-branched portions of creeping stems and larger in branching portions. The branch leaves have a more ovate shape, are more rigid, form a wider angle with the stem, and usually have the same size as stem leaves. A similar pattern can be observed in creeping phenotypes of E. pulchellum and some other species.

The foliage is typically subjulaceous, sometimes clearly julaceous (Myuroclada, Brachythecium cirrosum), or the branches are \pm complanate,for example in Brachythecium oedipodium, B. velutinum, and Eurhynchium hians. A complanate foliage mostly depends on a prostrate growth in shady habitats and all these species can develop subjulaceous branches when growing orthotropous (in more dense growth, etc.). The-leaves are usually lanceolate to ovate, rarely suborbicular (in Myuroclada and sometimes in Bryhnia), acute to acuminate, and sometimes abruptly contracted into a piliferous acumen (Cirriphyllum piliferum, Brachythecium cirrosum), concave to plane, and plicate to non-plicate.

Plicae are mostly due to the pattern of lateral contacts of laminal cells (Fig. 1). In Homalothecium the cells are ovate in transverse sections, and are joined with the neighbouring cells only along about a half the cell height. In Platyhypnidium riparioides, Eurhynchium hians, etc., the cells are nearly quadrate in transversal sec- 
tion, and the cells are joined along the entire cell height. This does not allow plicae to develop. Brachythecium is an intermediate case. Plicae mostly start from bends in the leaf insertion (the sharper these angles, the more distinct are the plicae). In some species (e. g., Homalothecium, Brachythecium salebrosum) the plicae are almost all longitudinal. In species with strongly concave leaves (e. g., Brachythecium complanatum), the convex surface of the basal leaf is never perfectly smooth and variously oriented folds occur throughout (Figs. 19-20).

At their base the leaves are shortly to longly and narrowly to broadly decurrent. However, decurrencies are not always observed in detached leaves, because they remain attached to stem. The study of a stem with partly detached leaves is the best way to study leaf decurrencies. The leaf margin is serrate to entire. The costa ends at 0.2 to 0.95 way up leaf, usually a little above mid-leaf, in the branch leaves (rarely in stem leaves) the costa ends in a tooth (rarely a few teeth). Lamina cell shape varies from linear to rhombic in the upper part of the leaf or, in Myuroclada, in most of the leaf, smooth or, in Bryhnia, with prorate upper cell ends.

Autoicous, diocous, rarer polyoicous ( $B$. mildeanum, $B$. rotaeanum) and phyllodioicous (Eurhynchium pulchellum) species occur, or sometimes the sexual condition is not stable within a species. The perichaetial leaves are straight to reflexed, not plicate, with a weak costa that is short or reaches about half way up sheating base, very rarely, in Brachythecium reflexum, ending in acumen. The seta is smooth to mammillose due to bulging to projecting ends of the seta cortical cells. The capsules are inclined to horizontal, sometimes cernuous (e.g.in B. oedipodium), rarely straight (in our species only in Homalothecium). The annulus is \pm well-developed, separating to sometimes remaining attached to the urn (e. g., Brachythecium buchananii). Opercular shapes vary between low-conic, high-conic, and rostrate. The exostome is xerocastique (teeth close the capsule mouth when wet, and open when dry), rarely (in Homalothecium) hygrocastique (teeth open the capsule mouth when wet). The teeth are cross-striolate below, and papillose above (for differences in exostome ornamentation see Ignatov $\&$ al., 1998a). The endostome has a basal membrane that reaches about $1 / 3$ of endostome height, and perforated segments, and well developed cilia (except Homalothecium). Whereas naked calyptras are typical, hairy ones are found in Brachythecium complanatum (hairy calypras are known in a few Homalothecium, Bryhnia, and other Brachythecium species from outside of Altai). Small to medium-sized and papillose, rarely smooth spores are typical in the family.

\section{COMMENTS ON TERMINOLOGY, MEASUREMENTS AND ILLUSTRATIONS}

Sympodial branch - branch which gradually starts "stem-like" growth, with subsequent branching. Leaves of sympodial branches often have characters transitional between stem and branch leaves. In some collections of species with extensive sympodial branching it is difficult to find "real" stem leaves.

Pseudoparaphyllia are here considered sensu lato, including all foliose structures around branch initial, and are not differentiated here from scaly, or embryonic leaves (cf. Ignatov, 1998).

Axillary hairs. The measurements were made on the better developed hairs only.

Width of laminal cells includes the width of lumen plus width of cell wall; the widths of two latter are indicated in brackets.

Seta and capsule length were measured from the dry herbarium specimens; capsule length does not include operculum.

For the species known in Altai by gametophytes only in square brackets are data on sexuality and sporophytes basing on studies of nonAltaian material and partly from literature.

The illustrations of habits, perichaetia, and capsules were done from the dry herbarium specimens. Other pictures were drawn from slides with water.

\section{KEy TO THE Altaian GENERA OF BRACHYTHECIACEAE}

1. Robust yellow-brownish plants with rigid, appressed, and deeply plicate leaves .... . 2

1. Leaves not rigid, deeply plicate and appressed ...................... 3

2. Saxicolous plants, rhizoids few ......... .. Homalothecium philippeanum (p.88)

2. Bog plants, with numerous rhizoids along most of the stem length and proximal part of costa ........ Tomentypnum (to be treated under Amblystegiaceae) 
3. Foliage distinctly julaceous, leaves closely imbricate, nearly orbicular (as wide as long), shortly acute to obtuse, median laminal cells short-rhomboidal; robust to medium-sized plants .............. Myuroclada (p. 140)

3. Foliage not or indistinctly julaceous, leaves ovate to lanceolate, median laminal cells long-rhomboidal to elongate or linear . . . 4

4. Costa stout, excurrent in a spine on the abaxial surface of stem leaf . . . . . . . 5

4. Costa stout, not excurrent in a spine on the abaxial surface of stem leaf . . . . . 7

5. Leaves narrowly lanceolate to lanceolate, operculum shortly conic (sporophytes frequent) ....... Brachythecium velutinum (p. 93)

5. Leaves ovate-lanceolate to broadly ovate; operculum long-conic to rostrate (sporophytes rare) ................6

6. Leaves variable within most of the shoots varying from widely obtuse below to acute and shortly acuminate above, widely decurrent, with distinctly delimited group of large thin-walled submarginal cells . . . ....................Bryhnia (p. 137)

6. Leaves within shoots slightly variable, shortly decurrent, with indistinctly delimited alar groups .... . E Eurhynchium (p. 141)

7. Robust aquatic plants, usually growing submerging in running water; leaves broadly ovate to elliptic, shortly acute, serrate all around; autoicous; operculum high-conic to rostrate ......... Platyhypnidium (p. 148)

7. Plants terrestrial, rarely growing in water; leaves lanceolate to ovate and suborbicular . . . . . 8

8. Leaves concave, obtuse to shortly apiculate; laminal cells lax, thin-walled, 9-12 $\mu \mathrm{m}$ wide, alar group of larger subquadrate cells well differentiated . . . . . . . . . .............. Scleropodiopsis (p. 149)

8. Leaves acute to acuminate; laminal cells not so lax ................... 9

9. Leaves concave, abruptly contracted into filiform acumina; operculum rostrate . . . . . Cirriphyllum (p.135)

9. Leaves acute or acuminate, rarely piliferous (Brachythecium cirrosum) ... . . . . . 10

10. Plants irregularly branched; leaves variable within most of the shoots varying from widely obtuse in the middle to acute and shortly acuminate above, widely decurrent; median laminal cells mostly rombic, 3-5:1 . . . . . . . Bryhnia (p. 137)

10. Leaves not so variable within one shoot; cells usually elongate .. Brachythecium (p. 89)

Homalothecium B. S. G.

This genus includes about 10 species distributed in temperate regions of the Northern Hemisphere. In the bryophyte flora of Russia it is represented by 3 species, $H$. sericeum, $H$. philippeanum and H. laevisetum, which are welldelimited by conspicuous characters of both sporophyte (capsule straight, exostome hygrocastique, outer surface of teeth with high dorsal trabeculae and high-branched papillae throughout or only upon its upper part, inner surface of teeth with strongly reduced ventral trabeculae, endostome with segments narrow and nonperforated to reduced and cilia short to lacking - cf. Ignatov \& al., 1998a) and gametophyte (leaves densely arranged, narrow-triangular to lanceolate, deeply longitudinally plicate). However, outside Russia the diversity of peristome of Homalothecium is greater and its differentiation from Camptothecium and Brachythecium is not so easy (cf. Ignatov \& al., 1998a).

Homalothecium philippeanum (Spruce) B. S. G., Bryol. Eur. 5: 93 (fasc. 46-47. Monogr. 3). 1851 .

Fig. 2

Isothecium philippeanum Spruce, Musci Pyren. 77. 1847.

Plants robust, yellow-brownish. Stem irregularly branched, leaves densely imbricate, branches little different from the stem. Axillary hairs (2)3-4-celled, to 50 x $8 \mu \mathrm{m}$, apical cell to $14 \mu \mathrm{m}$ long. Pseudoparaphyllia obtusely triangular. Stem leaves appressed, to $2.0 \mathrm{x}$ $0.7 \mathrm{~mm}$, lanceolate, gradually acuminate, widest just above the base; slightly concave and distinctly plicate; at base shortly decurrent; costa reaching (0.5) 0.6-0.8 of leaf length, to $50 \mu \mathrm{m}$ wide at base; margin serrulate throughout. Median laminal cells 25-60 x 4-5 (3-4/1) $\mu \mathrm{m}$; in leaf corner subquadrate cells forming \pm welldelimited group reaching $1 / 4-1 / 3$ of distance to costa. Branch leaves similar in shape, but narrower; costa not ending in spine. No gametangia or sporophytes were found in Altaian collection. [Dioicous. Seta mammillose, capsula straight, exostome hygrocastique, endostome with short segments. Calyptra naked].

From the other Altaian Brachytheciaceae this species differs in strongly plicate, rigid and very densely arranged leaves. The East Asian $H$. laevisetum is a variable moss, usually with 


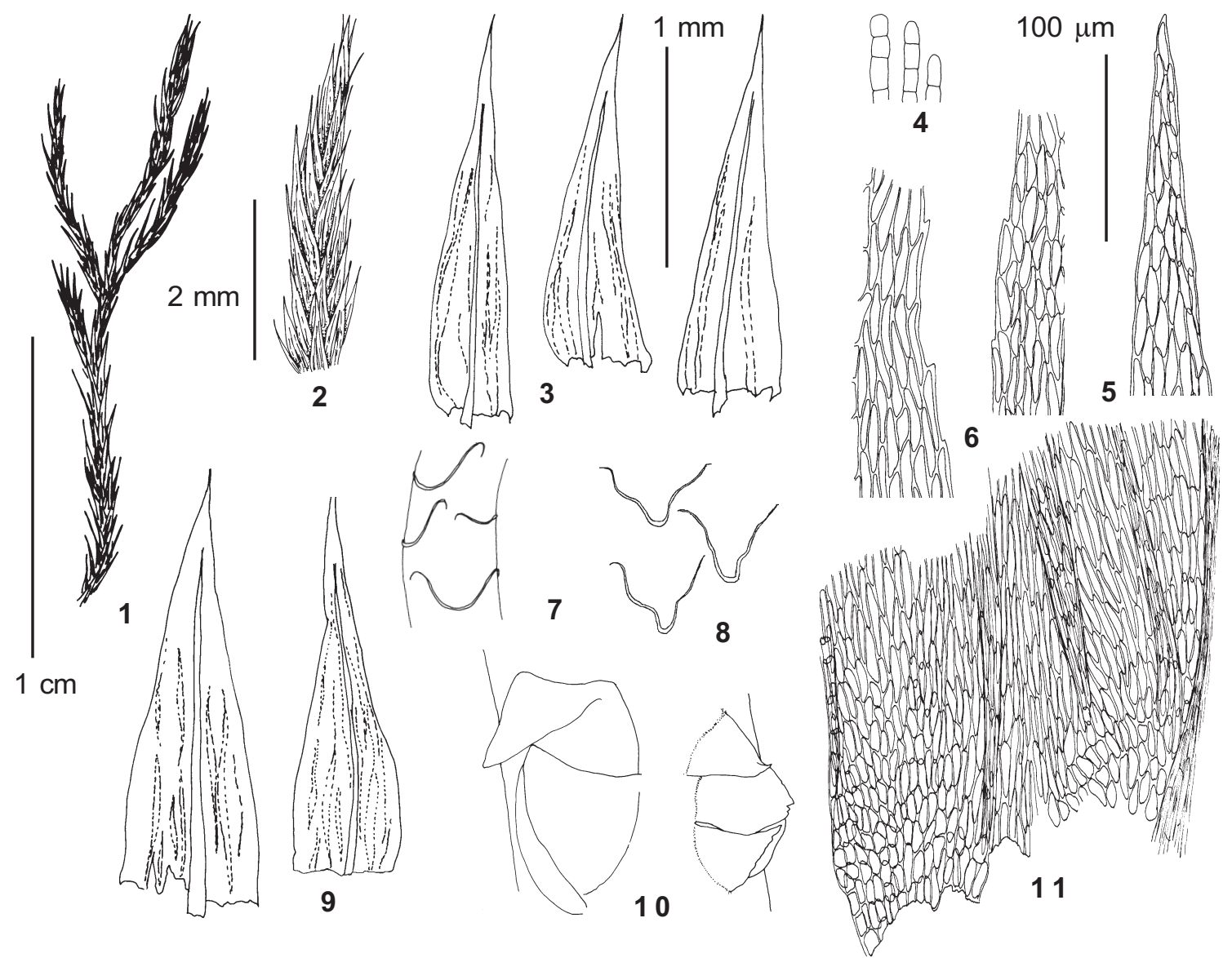

Fig. 2. 1-7,9-11. Homalothecium philippeanum (Spruce) B.S. G. (from Ignatov 21/32a), 8 - H. laevisetum Sande Lac. (from Musci Japonici 2: 94 (1948) MHA): 1 - habit; 2 - upper part of shoot; 3 - branch leaves; 4 - axillary hairs; 5 upper laminal cells of stem leaf; 6 - middle laminal cells of stem leaves; 7 - stem leaf insertions; 8 - stem leaf insertions (semi-schematic); 9 - stem leaves; 10 - branch initials with pseudoparaphyllia; 11 - basal cells of stem leaf. Scale bars: $1 \mathrm{~cm}$ for $1 ; 2 \mathrm{~mm}$ for $2 ; 1 \mathrm{~mm}$ for 3, 7-9, $100 \mu \mathrm{m}$ for $4-6,11$.

more loose foliage; however some phenotypes of $H$. laevisetum are superficially indistinguishable from $H$. philippeanum. They can be separated by the following:

$\begin{array}{lcc}\text { Character } H . \text { philippeanum } & \text { H. laevisetum } \\ \text { alar group } & \text { medium-sized } & \text { large } \\ \text { line of leaf insertion } & \text { arched } & \text { V-shaped (Fig. 1) } \\ \text { segments } & \text { short } & \text { absent }\end{array}$

Distribution: Homalothecium philippeanum is very common in Caucasus and South Europe (in Europe reaching north to Poland and Germany), Turkey, North Africa, mountain areas of Middle Asia from the Caspian Sea to eastern Kazakhstan (TianShan and Dzungarian Ala-Tau). In Altai H. philippeanum was found only once, on an exposed S-facing marble cliff on the northern shore of Telezkoye lake, a few shoots among Leucodon sciuroides.

Specimens examined: Azhi Cape $440 \mathrm{~m}(21 / 32 \mathrm{a})$.

\section{Brachythecium B. S. G.}

This genus is strongly heterogeneous and many authors have attempted to classify its species into more natural entities. Robinson (1962) suggested to split the genus into two genera Chamberlainia and Brachythecium (cf. Table 1). This suggestion however did not meet wide acceptance and later Robinson (1987) also noted the imperfectness of his early classification.

Most authors subdivide the genus into 4-8 sections (or groups of indefinite status) around (1) Brachythecium salebrosum; (2) B. velutinum; (3) B. rutabulum; (4) B. reflexum and (5) B. plumosum, sometimes also around (6) B. collinum; (7) B. albicans; (8) the American B. stereopoma (Spruce ex Mitt.) Jaeg., which is close to the East-Asian B. buchananii. 
Some infrageneric classifications of Brachythecium are represented in Table 1.

Though species of these infrageneric groups are very different, the raising of their status to the generic level is difficult because species with transitional combination of characters can be found between nearly all groups, for example $B$. falcatulum between groups/sections 1 and $2 ; B$. mildeanum and East Asian B. coreanum and B. kuroishicum Besch. between 1 and $3 ; B$. oedipodium and $B$. latifolium between 3 and 4; B. populeum between 4 and 5 , etc. It is probable, that among the numerous polyploids of Brachythecium (cf. Wigh, 1974) there are at least some allopolyploids, originating from species of different infrageneric units.

\section{KEY TO THE Altaian SPECIES OF BRACHYTHECIUM}

1. Plants usually with sporophytes (!this part of key doesn't include all species, but only those produce sporophytes in Altai relatively frequent $\ldots \ldots \ldots \ldots \ldots \ldots \ldots \ldots 2$

1. Plants without sporophytes ........ 11

2. Seta mammillose ............... 3

2. Seta smooth .............. 21

3. Costa reaching $0.8-0.9$ of leaf length . . . 4

3. Costa reaching 0.4-0.75 of leaf length . . 6

4. Stem leaves ovate-lanceolate, gradually narrowed into erect point; leaf length: width ratio 2.5-4.0:1 ... . . B. populeum (p. 130)

4. Stem leaves with broadly ovate-triangular basal part, rather suddenly narrowed into acumen; leaf length:width ratio 1.52.5:1

5. Median laminal cells wide, 4-7(10):1 . . . ................ B. reflexum (p. 125)

5. Median laminal cells flexuose, narrow, 8-15:1 B. starkei (p. 126)

6. Leaves narrow, less than $0.5 \mathrm{~mm}$ wide $\ldots 7$ 6. Leaves wider $\ldots \ldots \ldots \ldots \ldots \ldots$

7. Costa in stem leaves ending in distinct tooth; branch leaves narrowly acute to shortacuminate; spores 10-14 $\mu \mathrm{m}$, smooth . . . . . . . ................. B. velutimum (p. 93)

7. Costa in stem leaves not ending in distinct tooth; branch leaves narrowly long-acuminate; spores 13-17 $\mu \mathrm{m}$, papillose . . . . . . . . B. trachypodium (p. 96)

8. Laminal cells thick-walled and narrow almost to the leaf base .......... 9
8. Laminal cells thin-walled; basal cell markedly larger than median laminal cells, forming extensive translucent area . . . . . 10

9. Leaves plane, falcate-secund; subquadrate cells forming compact groups in leaf corners; seta with very low mammillae . . . . . . .

B. falcatulum (p. 97)

9. Leaves concave, straight; subquadrate cells forming extensive opaque area across entire leaf base; seta mammillose .. B. plumosum (p. 132)

10.Plants medium-sized; branch foliage \pm complanate; stem leaves ovate-triangular, not plicate; costa in branch leaves ending in a distinct spine; broad cells at leaf base forming rather homogeneous area, alar group not well delimited; capsule ovoid-cylindric, horizontal to pendent .............. B. oedipodium (p.130)

10.Plants robust; branch foliage subjulaceous; stem leaves ovate, more or less plicate; costa in branch leaves not ending in a distinct spine; alar group of larger cells rather clearly delimited in leaf corners; capsule ovoid, inclined to horizontal ........... B. rutabulum (p. 115)

11. Costa reaching $0.8-0.9$ of leaf length . . 12 11. Costa reaching $0.4-0.75$ of leaf length . . 13

12.Plants irregularly branched, shoots densely imbricate, stem invisible among leaves; alpine moss ....... B. dovrense (p. 125)

12.Plants \pm regularly pinnate, loosely imbricate, stem often seen among leaves; mostly in forest zone ................ 4

13.Plants small, leaves less than $0.5 \mathrm{~mm}$ wide ...................... 14

13. Plants robust to medium-sized, leaves 0.6 $1.0(1.5) \mathrm{mm}$ wide $\ldots \ldots \ldots \ldots \ldots . \ldots$

14.Plants small, julaceous; stem leaves less than $1 \mathrm{~mm}$ long ... B. collinum (p. 92) 14. Plants larger, not julaceous . . . . . . . 15

15. Cells in lower half of leaves to 8-10 $\mu \mathrm{m}$ wide, forming extensive laxly areolated zone; stem leaves concave, often plicate, usually entire (serrulate in smaller phenotypes); dioicous ......... B. buchananii (p. 107)

15. Cells in lower half of leaves as wide as in mid-leaf, 5-7 $\mu \mathrm{m}$ or slightly wider in 1-3 rows; stem leaves serrate to serrulate, non-plicate; autoicous .................. 7 


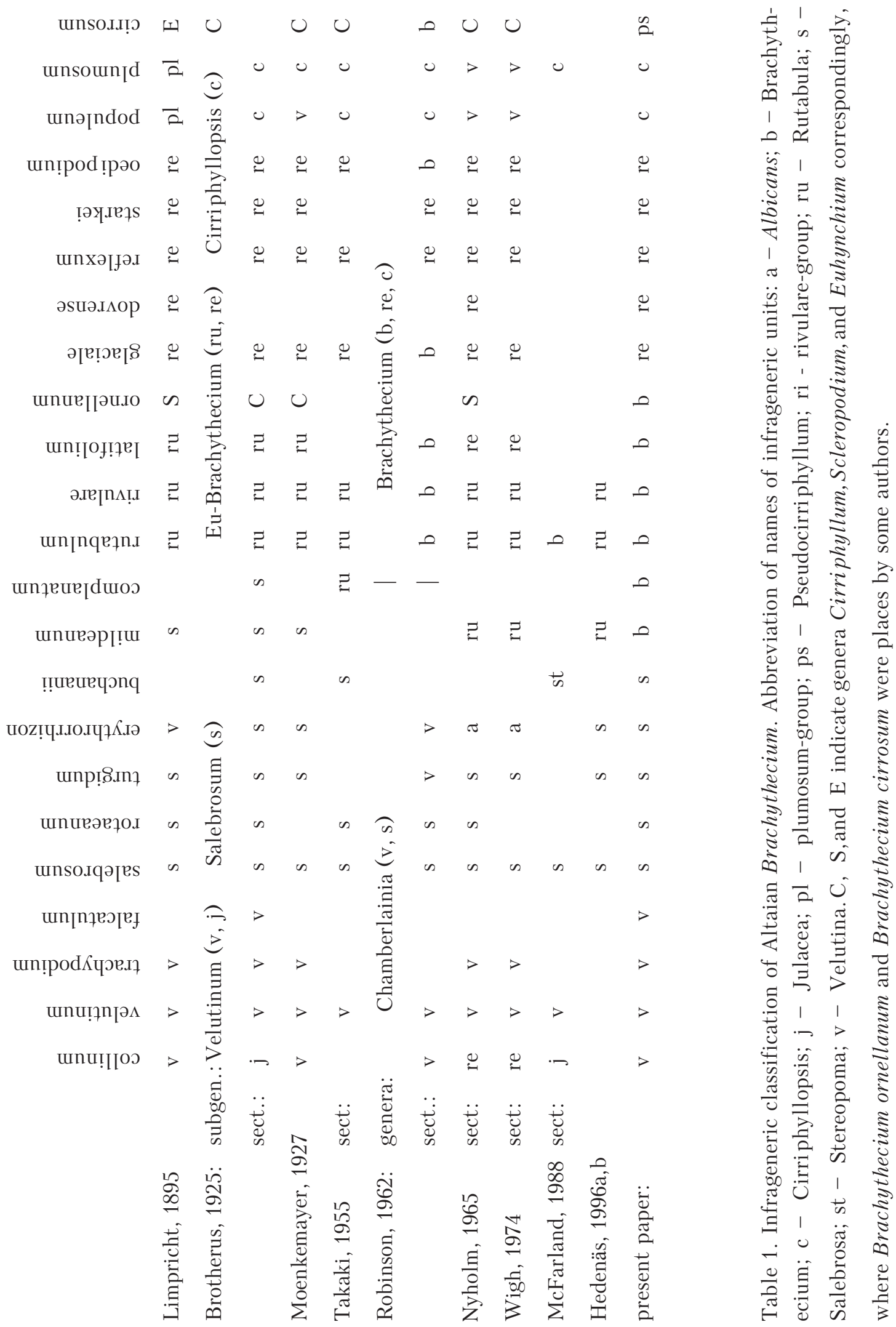


16. Leaves concave, abruptly contracted into piliform acumen ... B. cirrosum (p. 133)

16. Leaves not piliferous . . . . . . . . . . . 17

17. Leaves not plicate; laminal cells thick-walled; subquadrate cells forming extensive opaque area across entire leaf base; plants growing on wet rocks ....... B. plumosum (p. 132)

17. Leaves plicate, rarer not plicate; basal cells not forming extensive opaque area across entire leaf base .................. 18

18. Stem leaves \pm lanceolate, $2.5-4: 1 \ldots$. . . 19 18. Stem leaves ovate to ovate-lanceolate, 1.5$3: 1 \ldots \ldots \ldots \ldots \ldots \ldots \ldots \ldots \ldots . \ldots 24$

19. Autoicous; leaves serrulate; alar group \pm subquadrate, consisting of small cells . . . 20

19. Dioicous; leaves entire or slightly serrulate; basal cells in leaf corner or across entire base relatively large . . . . . . . . . . 23

20. Leaves not plicate, \pm falcate-secund; seta lowly mammillose .. B. falcatulum (p. 97) 20. Leaves plicate; seta smooth . . . . . . 21

21. Little branched alpine plants; leaves densely imbricate, straight; laminal cell walls thick $(2.0-3.0 \mu \mathrm{m}) \ldots$. . . B. turgidum (p. 103)

21. Normally branched plants of forest zone; leaves erect or somewhat falcate; laminal cells with less thick walls $(1.5-2.0 \mu \mathrm{m}) \ldots . .22$

22. Plants usually pure green to whitish-green with some glaucous tint; leaves \pm appressed in their basal parts, straight, concave; basal cells laxer than laminal cells in 5-7 rows; alar cells subquadrate, with relatively thin walls; capsule straight below, inclined above .... B. rotaeanum (p. 101)

22. Plants usually yellow-green; leaves erect, often \pm falcate; basal cells laxer than laminal cells usually in (1-)2-4 rows; alar cells subquadrate, relatively thick-walled; capsule inclined .... B. salebrosum (p. 99)

23. Leaves straight, slightly plicate; basal cells homogeneous, alar group not differentiated or sometimes composed of enlarged cells indistinctly delimited from surrounding cells . . . . . . . . B. mildeanum (p. 110)

23. Leaves falcate, strongly plicate; alar group welldifferentiated .. B. erythrorrhizon (p. 100)

24. Basal cells \pm homogeneous, alar cells not or weakly delimited . . . . . . . . . . . 25

24. Alar cells well-differentiated ...... 26
25.Plants medium-sized to robust; leaves not plicate ........ B. oedipodium (p.130)

25. Plants robust; leaves strongly plicate . . . . . B. complanatum (p. 113)

26. Medium-sized to robust plants, more common at higher elevations; stem leaves entire or weakly serrulate above . . . . . . 27

26 . Robust plants, more common at lower elevations, stem leaves serrulate . . . . . 29

27.Alar cells small .... B. glaciale (p. 122)

27. Alar cells enlarged, inflated . . . . . . . 28

28. Shoots subjulaceous; leaves gradually acuminate, moderately concave; branch leaves subentire .. B. latifolium (p. 119)

28. Shoots julaceous; leaves broadly acute or apiculate, strongly concave; branch leaves serrulate above . . B. ornellanum (p. 119)

29. Autoicous; stem leaves shortly acuminate; transition between alar cells and surrounding cells \pm gradual; sympodial branching rare ............... B. rutabulum (p. 115)

29.Dioicous; stem leaves acute; alar cells abruptly differentiated; sympodial branches numerous, frequently subdendroid ..... . .................. rivulare (p. 115)

Sect. Velutina (De Not.) Broth., Nat. Pfl. 1(3): 1145. 1909. - "group Velutina" De Not., Atti Univ. Genova 1: 107. 1869.

Plants slender to medium-sized; stem leaves narrowly lanceolate to ovate-lanceolate, non-plicate; branch leaves often falcate; laminal cells narrow; alar cells in small subquadrate group; seta mammillose to smooth; capsule ventricose, variegate when premature.

Brachythecium collinum (Schleich. ex C. Muell.) B.S.G., Bryol. Eur. 6: 19. 548. 1853. Hypnum collinum Schleich. ex C. Muell., Syn. Musc. Frond. 2:429.1851. Fig. 3

Plants slender, deep yellow-green to yellowbrown, \pm fragile. Stem irregularly branched, branches julaceous, to $4 \mathrm{~mm}$ long, sympodial branches numerous. Pseudoparaphyllia obtusely-triangular. Axillary hairs 2-3-celled, to $25-35 \times 7-8 \mu \mathrm{m}$, apical cell to $18 \mu \mathrm{m}$ long. Stem leaves erect-appressed, 0.7-1.0 x 0.3-0.4 mm, ovate-lanceolate, gradually to abruptly acuminate, widest at $1 / 3-1 / 4$ of leaf length; concave, with submarginal plicae; at base shortly decurrent; costa reaching (0.2) 0.5-0.7 of leaf length, $25-33 \mu \mathrm{m}$ wide at base; margin serrate throughout. Median laminal cells very variable in shape, 20-50 x 3.5-6 (2.5-5/1.0-1.5) $\mu \mathrm{m}$; in leaf corner subquad- 

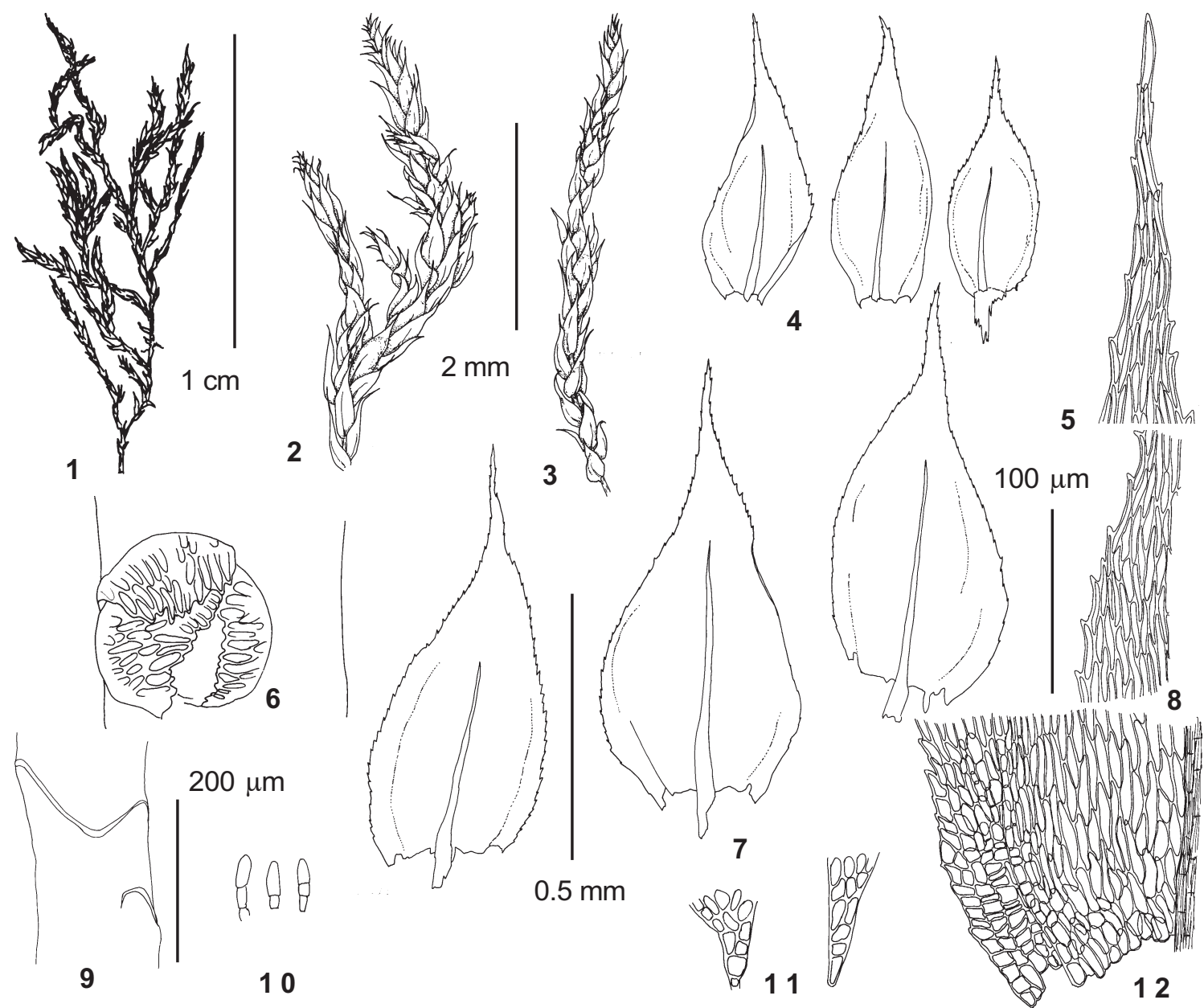

Fig. 3. Brachythecium collinum (Schleich. ex C. Müll.) B. S. G. (from Ignatov 31/55): 1 - habit; 2-3 - upper parts of shoots; 4 - branch leaves; 5 - upper laminal cells of stem leaf; 6 - branch initial with pseudoparaphyllia; 7 - stem leaves; 8 - middle laminal cells of stem leaf; 9 - stem leaf insertion; 10 - axillary hairs; 11 - leaf decurrencies; 12 basal cells of stem leaf. Scale bars: $1 \mathrm{~cm}$ for $1 ; 2 \mathrm{~mm}$ for $2-3 ; 0.5 \mathrm{~mm}$ for 4,$7 ; 200 \mu \mathrm{m}$ for $9 ; 100 \mu \mathrm{m}$ for $5,8,12$.

rate cells forming small \pm well delimited square group. Branch leaves shorter and narrower; costa ending in short spine. No gametangia and sporophytes were found in Altaian collections. [Autoicous; seta mammillose; capsule short, little curved, slightly inclined].

Brachythecium collinum differs from the other species of the genus in the exceptionally small plants with julaceous shoots and small concave leaves with narrow, flexuose laminal cells. Some alpine phenotypes of $B$. velutinum with imbricate and relatively short leaves are similar to B. collinum. They are discussed under the latter species.

Distribution: This species is widely distributed in many parts of the Holarctic, but is common only in xeric areas like Middle Asia, South-Eastern Caucasus, countries of Middle East, internal territories of North America. In Altai it is known from a few localities in xeric high mountains where it grows on soil and rocks in tundro-steppe types of vegetation.

Specimens examined: Bogoyash Creek, upper course 2350 m (36/417); Kobiguayuk Creek 2300 m (0/448); Tabozhok Creek, 12 km upstream $2200 \mathrm{~m}$ (30/139); Tabozhok Peak 2750 m (31/55); Trekhglavaya Peak $2850 \mathrm{~m}$ (Zolotukhin 19.VII.1990).

Brachythecium velutinum (Hedw.) B.S.G., Bryol. Eur. 6: 9 (fasc. 52-54. Monogr. 5). 1853.

Fig. 4, 5-1,2

Hypnum velutinum Hedw., Sp. Musc. Frond. 272. 1801. - Eurhynchium velutinum (Hedw.) Géneau de Lamarliere et Maheu, J. Bot. (Desvaux) 16: 274. 1902.

Brachythecium collinum var. altaicum Broth., in sched.

Plants slender, deep green to yellow-brownish. Stem \pm regularly branched, branches with 


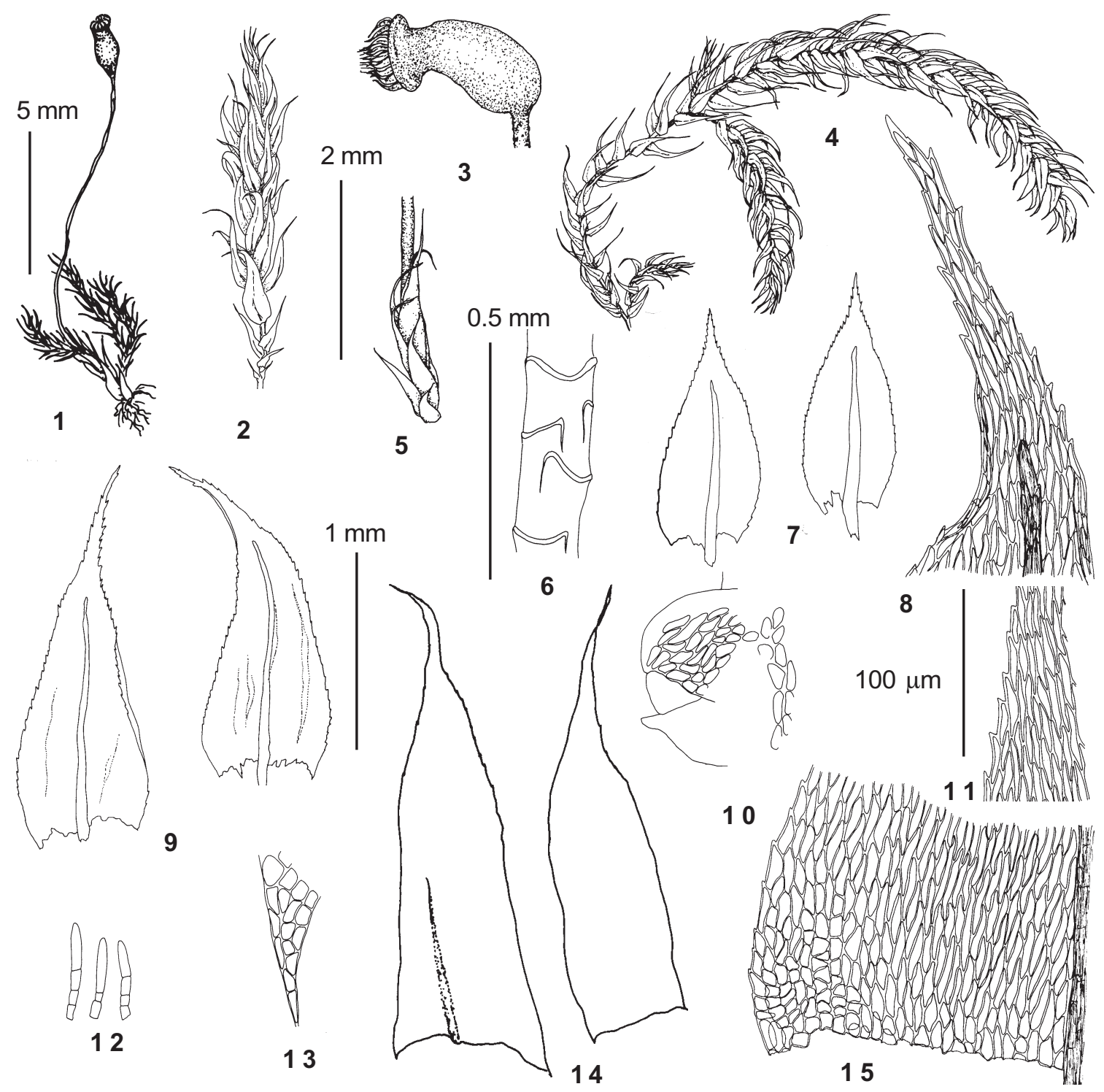

Fig. 4. Brachythecium velutinum (Hedw.) B. S. G., 1-3 \& 5-15 - from tundra communities; 4 - from forest community (1-2 - from Kusnezov, 2705; 3, 5-15 - from Ignatov 13/134; 4 - from Ignatov 3/149): 1 - habit; 2, 4 upper part of shoots; 3 - capsule; 5 - perichaetium; 6 - stem leaf insertions; 7 - branch leaves; 8 - upper laminal cells of stem leaf; 9 - stem leaves; 10 - branch initial with pseudoparaphyllia; 11 - median laminal cells of stem leaf; 12 - axillary hairs; 13 - leaf decurrency; 14 - inner perichaetial leaves; 15 - basal cells of stem leaf. Scale bars: $5 \mathrm{~mm}$ for $1 ; 2 \mathrm{~mm}$ for $2-5 ; 1 \mathrm{~mm}$ for $7,9,14 ; 0.5 \mathrm{~mm}$ for $6 ; 100 \mu \mathrm{m}$ for $8,10-13,15$.

\pm complanate foliage. Axillary hairs 3-4-celled, to $50 \times 7 \mu \mathrm{m}$, apical cell $35 \mu \mathrm{m}$ long. Stem leaves $1.0-1.5 \times 0.3-0.4(0.5) \mathrm{mm}$, lanceolate, gradually acuminate, widest at ca. 1/10 of leaf length; slightly concave and sometimes indistinctly plicate; at base very shortly decurrent; costa reaching $0.45-0.7$ of leaf length, $20-25 \mu \mathrm{m}$ wide at base; margins serrate to serrulate throughout. Median laminal cells $28-60$ x 5.5-6.5 (4-5/1.5-2.0) $\mu \mathrm{m}$; near base wider (to 7-9 $\mu \mathrm{m}$ ) in 1-3 rows or undifferentiated; in leaf corner small group of subquad- rate cells \pm well delimited, reaching $1 / 2-1 / 3$ of distance to costa. Branch leaves similar in shape, but narrower; costa ending in distinct spine, and often with several teeth on the dorsal surface near its end. Some laminal cells in upper part with strongly projecting upper corners. Perichaetial leaves abruptly longly acuminate. Seta to $1.3 \mathrm{~mm}, \pm$ low-mammillose. Capsule $1.5 \mathrm{~mm}$ long, inclined. Operculum shortconic. Spores 10-14 $\mu \mathrm{m}$, smooth.

In the forest zone of Altai Brachythecium velutinum is rather uniform. The plants are green, 

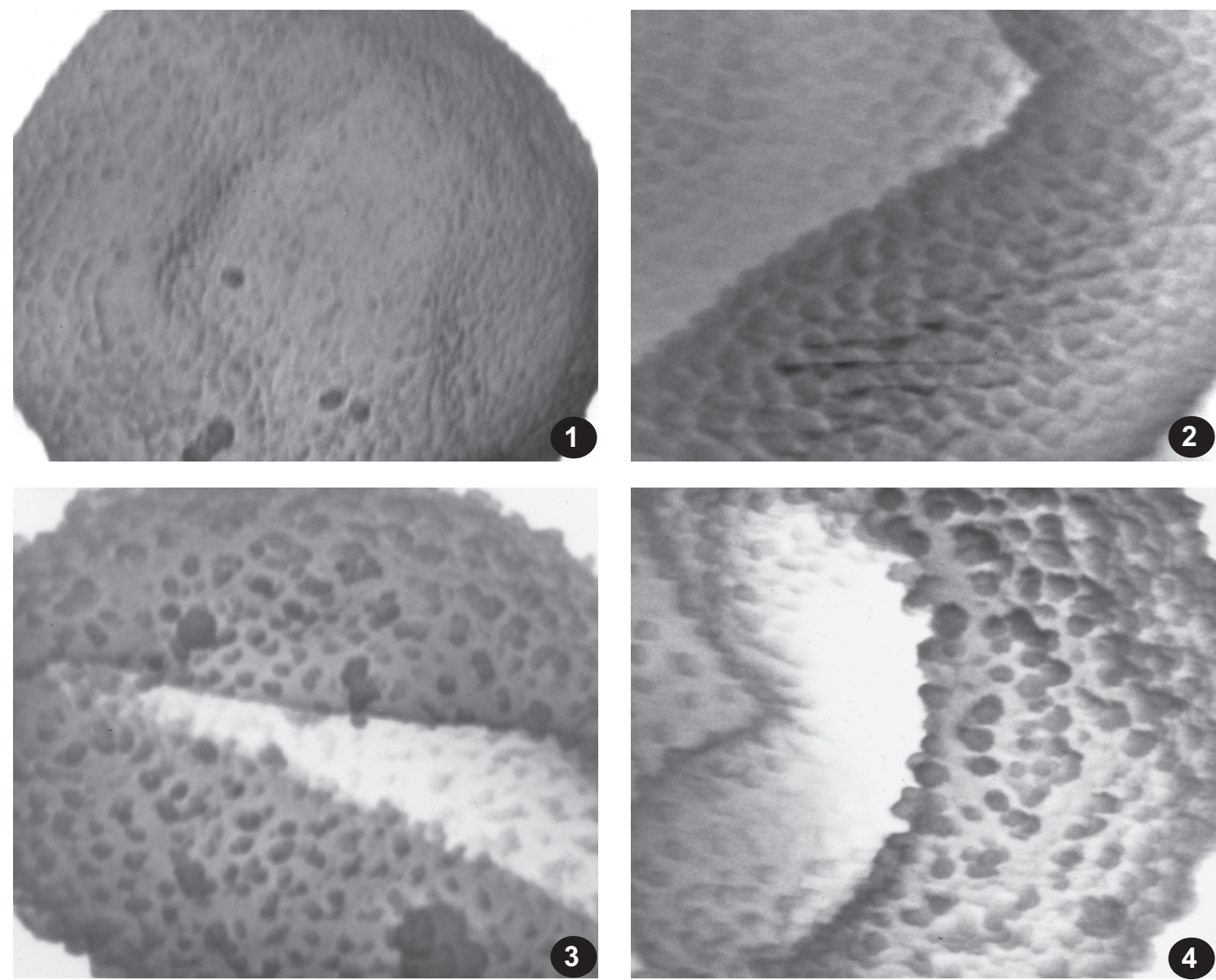

Fig 5. Spores: 1-2 - Brachythecium velutinum (Hedw.) B. S. G. (1 - from Altai, Ignatov 13/134; 2 - from Moscow Province, Ignatov 20.VII.1988 MHA); 3 - B. trachypodium (Funck ex Brid.) B.S.G. (from Altai, Ignatov 31/227); 4 B. falcatulum (Broth.) Par. (from Altai, Ignatov 0/1680). 1 - 11500x; 2 - 19000x; 3 - 12500x; $4-14000 x$.

the stem leaves gradually acuminate and strongly serrate, the branch leaves wide-spreading and somewhat falcate and the laminal cells are narrow often almost to the base. In high mountains some phenotypes have shorter leaves and mostly subjulaceous branch leaves. Such plants were named B. collinum var. altaicum by Brotherus ("Altai, in alpibus ad. fl. Topchugan, 2425.VII.1913, leg. Kusnezov, 2705, H-BR”, on label, never published). However these alpine plants have leaves that are longer than in $B$. collinum, their leaf cells are not as irregular as in $B$. collinum, the costa is longer and ends in a longer spine in both the branch and stem leaves, and in extensive specimens one can find at least a few shoots with longer, spreading and complanate leaves. Therefore this phenotype is interpreted as a response to severe al- pine condition and dense growth. Differences between $B$. velutinum and $B$. trachypodium and $B$. falcatulum are discussed under the latter species.

Distribution: Very common species in many parts of the Holarctic, especially in boreal regions with calcareous soils. In Altai it is known from scattered localities in the forest to lower alpine belts, where it grows on soil and rock outcrops, sometimes on rotten logs and bases of aspen trunks.

Specimens examined: Gorno-Altaisk ( $S E$ edge) 550 m (23/27a); Kairu-Bazhi Peak 2300 m (13/134; 13 180); Karakol Lakes 1900 m (28/138); Kayakkatuyarykskij Creek 1940 m (3/149), 2000 m (3/222); Kukol $1800 \mathrm{~m}(0 / 1232)$; Kyga River, $2 \mathrm{~km}$ upstream $600 \mathrm{~m}$ (0/1670); Topchugan (Kusnezov 2705, H-BR); Turochak Creek, in middle course $950 \mathrm{~m}$ (Zolotukhin \& al. 5.VI.1986); Uedinennoye Lake $880 \mathrm{~m}$ (0/1684); Yazula $1700 \mathrm{~m}(0 / 1688)$. 


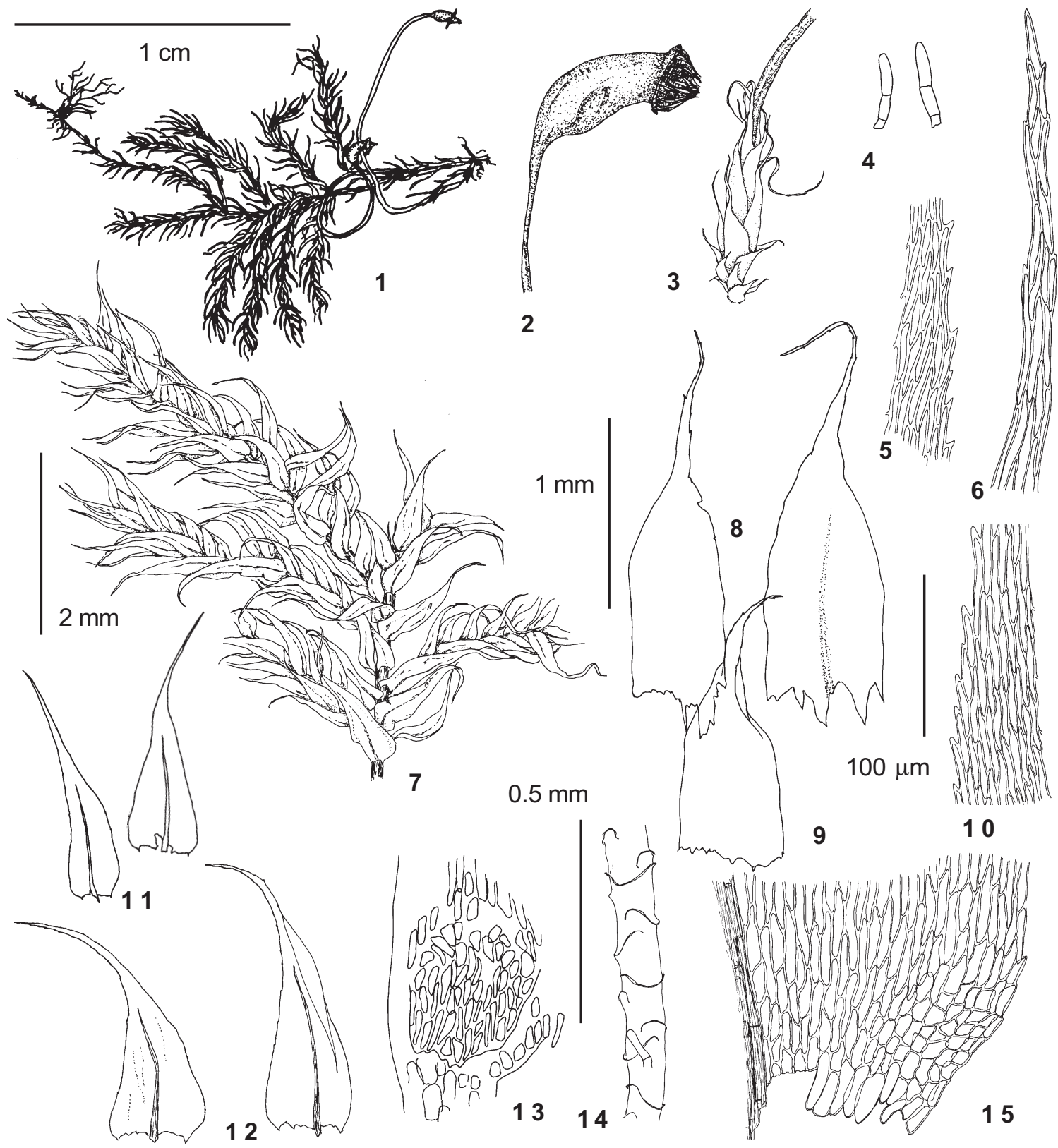

Fig. 6. Brachythecium trachypodium (Funck ex Brid.) B.S.G., (from Ignatov 0/1232): 1,7 - habit; 2 capsule; 3 - perichaetium; 4 - axillary hairs; 5 - median laminal cells of branch leaf; 6 - upper laminal cells of stem leaf; 8 - inner perichaetial leaves; 9 - outer perichaetial leaf; 10 - median laminal cells of stem leaf; 11 - branch leaves; 12 - stem leaves; 13 - branch initial with pseudoparaphyllia; 14 - stem leaf insertions; 15 - basal cells of stem leaf. Scale bars: $1 \mathrm{~cm}$ for $1 ; 2 \mathrm{~mm}$ for 2-3, 7; $1 \mathrm{~mm}$ for 8-9, 11-12; $0.5 \mathrm{~mm}$ for 14; $100 \mu \mathrm{m}$ for 4-6, 10, 13, 15 .

Brachythecium trachypodium (Funck ex Brid.) B.S.G., Bryol. Eur. 6: 11 (fasc. 52-54. Monogr. 7). 1853. Fig. 5-3, 6, 7

Isothecium trachypodium Funck ex Brid., Bryol. Univ. 2: 766. 1827.

Plants slender, green to yellow and brownish. Stem pinnately to fasciculately branching, branches with complanate to julaceous foliage. Axillary hairs 3-celled, to $55 \times 6.5 \mu \mathrm{m}$, apical cell to $35 \mu \mathrm{m}$ long. Stem leaves $0.8-1.8 \times 0.25-0.45 \mathrm{~mm}$, lanceolate, gradually acuminate, widest just above base; slightly concave, sometimes indistinctly plicate; at base shortly decurrent; costa reaching 0.4-0.6 of leaf length, 25 $\mu \mathrm{m}$ wide at base; margin serrulate throughout to subentire (in more narrow leaves). Median laminal cells 


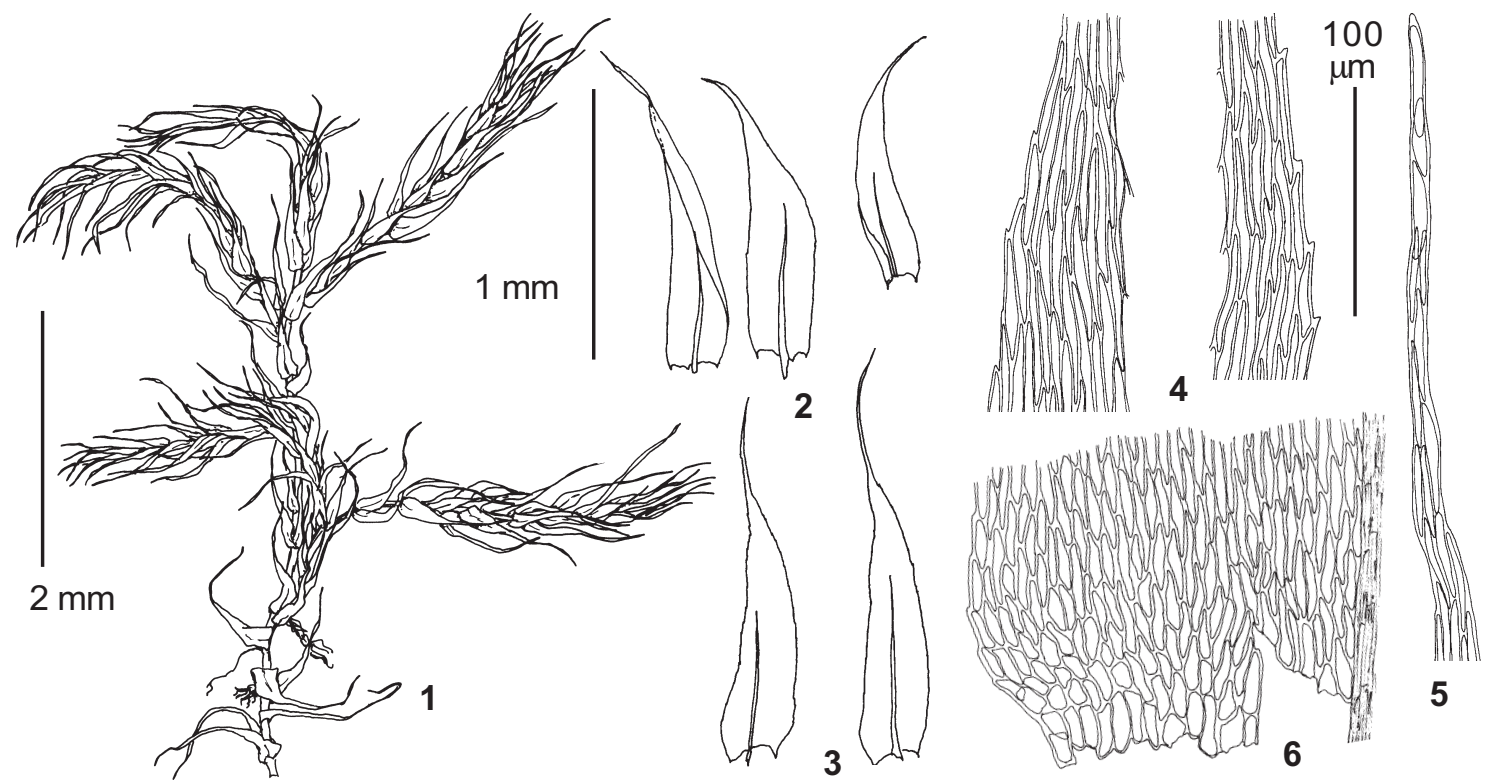

Fig. 7. Brachythecium trachypodium (Funck ex Brid.) B.S.G., slender phenotype (from Ignatov 31/227): 1 habit; 2 - branch leaves; 3 - stem leaves; 4 - median laminal cells of stem leaf; 5 - upper laminal cells of stem leaf; 6 - basal cells of stem leaf. Scale bars: $2 \mathrm{~mm}$ for 1; $1 \mathrm{~mm}$ for 2-3, $100 \mu \mathrm{m}$ for 4-6.

30-75 x 5 (3.5-4/1.0-1.5) $\mu \mathrm{m}$; alar cells in small group, \pm well delimited, reaching $1 / 3$ of distance to costa. Branch leaves similar in shape, but narrower; costa ending in distinct or indistinct spine. Perichaetial leaves abruptly longly acuminate. Seta to 1.5 $\mathrm{mm}, \pm$ low-mammillose. Capsule $1.8 \mathrm{~mm}$ long, inclined. Operculum short-conic. Spores 14-17 $\mu \mathrm{m}$, papillose.

Brachythecium trachypodium differs from $B$. velutinum in having plants yellowish to golden (vs. green), with leaves erect to erectopatent (vs. almost spreading), longly acuminate (vs. shortly acuminate to acute), less serrate leaf margin and costa, spores larger and finely papillose (vs. smooth).

Brachythecium trachypodium is rather common in xeric areas of Altai and looks quite distinctive from $B$. velutinum. However some collections have plants with gametophytes more or less transitional between these two species. Fortunately, many collections of both species have capsules, and character of spores (cf. Figs. 5) helps much in distinction of these ambigous cases. As far as I know, the nearly smooth spores of $B$. velutinum is a unique case in Brachytheciaceae.

Distribution: The distribution of B. trachypodium is insufficiently known because its unclear differentiation from B. velutinum. Düll (1985) reported $B$. trachypodium from many European countries, and also from North America, North Africa, northern and western Asia. We have seen specimens identical to Altaian ones from Central Asia, Caucasus and Cen- tral Europe (though in general European specimens are somewhat larger than Altaian and Central Asian ones). In Altai B. trachypodium is more common at higher elevations of South-Eastern Altai, on xeric rock outcrops and soil in tundro-steppes and dry forests.

Specimens examined: Ayulyuyuzyuk Creek $2000 \mathrm{~m}$ (0/146); Berekhtuyaryk $1650 \mathrm{~m}(0 / 1686)$; Kairu Creek, $8 \mathrm{~km}$ upstream $1000 \mathrm{~m}$ (15/12); Kayakkatuyarykskij Creek 1850 m (8/289); Kobiguayuk Creek 2300 m (0/ 1666; 0/321); Kokorya Creek $2100 \mathrm{~m}(32 / 37)$; Kukol $1700 \mathrm{~m}(0 / 1683), 1750 \mathrm{~m}(0 / 1685 ; 0 / 494), 1800 \mathrm{~m}(0 /$ 1658; 0/1690), $1900 \mathrm{~m}(0 / 493), 2000 \mathrm{~m}(0 / 1682)$; Tabozhok Creek, 12 km upstream $2200 \mathrm{~m}(30 / 80 ; 30 /$ 82); Tabozhok Creek, 8 km upstream $2050 \mathrm{~m}$ (30/81); Tabozhok Peak 2150 m (31/226), 2200 m (31/229), 2250 $\mathrm{m}(30 / 50 ; 31 / 232), 2300 \mathrm{~m}(31 / 227 ; 31 / 230 ; 31 /$ 231; 31/235), $2350 \mathrm{~m}(31 / 228), 2500 \mathrm{~m}(0 / 1669 ; 31 /$ 295), $2550 \mathrm{~m}$ (31/173), $2700 \mathrm{~m}(31 / 233 ; 31 / 234) ; Y a-$ khansoru Lake 1870 m (Zolotukhin 28.VI.1990).

Brachythecium falcatulum (Broth.) Par., Ind. bryol. Suppl.: 43. 1900. - Hypnum (Brachythecium) falcatulum Broth., Acta Soc. Sci. Fenn. 24(2): 34.1898 (1899). Fig. 5-4, 8

Plants medium-sized to robust, \pm regularly pinnately branched, intensively colored from deep green to rich golden or golden-brownish. Axillary hairs 2-3celled, upper hyaline cell ca. $35 \mu \mathrm{m}$ long. Stem leaves erecto-patent, slightly falcate, ovate-lanceolate, acuminate, slightly concave, slightly plicate, 1.3-1.7 x 0.5$0.7 \mathrm{~mm}$; costa reaching $0.45-0.65$ of leaf length, 30-45 $\mu \mathrm{m}$ wide at base; margins plane or near leaf base slightly recurved, serrulate to subentire below. Median laminal cells 30-65 x 5.5-7 (4-5.5/1.5-2) $\mu \mathrm{m}$; basal cells 


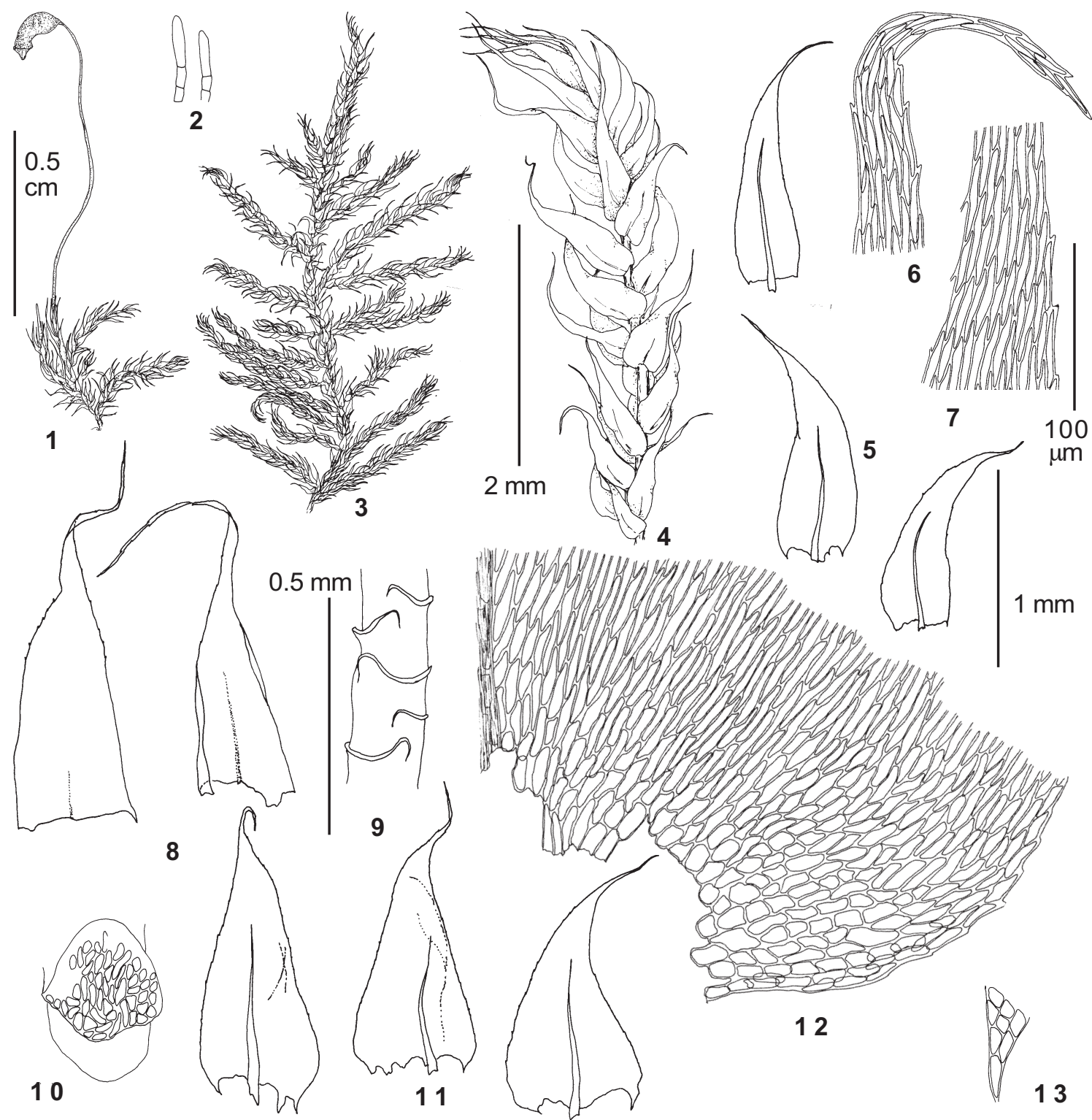

Fig. 8. Brachythecium falcatulum (Broth.) Par. (from Ignatov 0/1680): 1, 3 - habit; 2 - axillary hairs; 4 - distal part of branch; 5 - branch leaves; 6 - upper laminal cells of stem leaf; 7 - median laminal cells of stem leaf; 8 - inner perichaetial leaves; 9 - stem leaf insertions; 10 - branch initial with pseudoparaphyllia; 11 - stem leaves; 12 - basal cells of stem leaf; 13 - leaf decurrency. Scale bars: $0.5 \mathrm{~cm}$ for 1,$3 ; 2 \mathrm{~mm}$ for $4 ; 1 \mathrm{~mm}$ for $5,8,11 ; 0.5 \mathrm{~mm}$ for $9 ; 100 \mu \mathrm{m}$ for 2, 6-7, 10, 12-13.

shorter and wider in few rows or undifferentiated; alar group of short-rectangular to subquadrate cells (10 $\mu \mathrm{m}$ wide) well-delimited. Branch leaves smaller than stem leaves, more strongly serrate. Autoicous. Seta 12-20 mm long, smooth (outside Altai) to indistinctly mammillose; capsule inclined to horizontal, distinctly constricted below mouth when dry, $1.5 \mathrm{~mm}$ long; operculum conic; annulus separating, of 2 rows of large cells. Peristome well-developed, cilia 2-3, nodose or appendiculate. Spores 10-14 $\mu \mathrm{m}$, papillose.

Brachythecium falcatulum is close to $B$. velutinum in having (1) \pm falcate-secund leaves that are only slightly concave and plicate; (2) a serrulate leaf margin; (3) narrow and relatively thick-walled laminal cells almost to the leaf base; (4) a subquadrate group of alar cells; (5) autoicous sexuality; (6) relatively short capsule, distinctly constricted below mouth when dry and ventricose and variegate when premature (partly green, partly ferruginaceous due to uneven ripening). The main difference between B. falcatulum and B. velutinum is in leaf size, resulting in similarities of the former to slender 
phenotypes of $B$. salebrosum, rather than to $B$. velutinum; $B$. salebrosum differs from $B$. falcatulum in its strongly plicate leaves.

Distribution: Brachythecium falcatulum was described from Kashmir, and was subsequently found in other regions of the Himalayas, Kazakhstan and Kirgizstan (collections in H-BR!), and reported also from Pakistan (Nishimura \& Higuchi, 1993). In Altai it was collected only once on rocks in relatively xeric area of Central Altai.

Specimen examined: Berekhtuyaryk $1600 \mathrm{~m}$ (0/1680).

Sect. Salebrosa (Limpr.) Broth., Nat. Pfl. 1(3): 1142. 1909. - "group Salebrosa" Limpr., Laubm. 3: 62. 1895.

Plants medium-sized to robust; stem leaves lanceolate to ovate-lanceolate, plicate; laminal cells narrow; alar cells not much enlarged; seta smooth (except the European B. campestre); capsule slightly to strongly inclined to horizontal.

Brachythecium salebrosum (Web. et Mohr) B.S.G., Bryol. Eur. 6: 20 (fasc. 52-54. Monogr. 16). 1853 .

Fig. 9, 10

Hypnum salebrosum Web. et Mohr, Bot. Taschenb. 312. 1807.

Plants green to yellow-brownish. Stem regularly pinnately branched, branches subjulaceous, to 6 $\mathrm{mm}$ long. Pseudoparaphyllia long-triangular to lanceolate. Axillary hairs 2-3-celled, 40-75 x $9 \mu \mathrm{m}$, apical cell to $55 \mu \mathrm{m}$ long. Stem leaves erect-spreading, $2.0-2.5 \times 0.7-0.9 \mathrm{~mm}$, lanceolate to narrowly ovatelanceolate, \pm gradually acuminate, widest at ca. 1/7 of leaf length; concave and strongly plicate; at base shortly decurrent; costa reaching $0.60-0.75$ of leaf length, ca. 40-70 $\mu \mathrm{m}$ wide at base; margin serrulate to serrate throughout, rarely nearly subentire (in wet, shady places). Median laminal cells 45-90 x 6.5-9 (5-7/1.5-2.0) $\mu \mathrm{m}$; in leaf corners subquadrate cells forming \pm well delimited quadrate group reaching 1/3-1/4 of distance to costa. Branch leaves similar in shape, but narrower, more serrate and costa ending in distinct spine. Autoicous. Perichaetial leaves abruptly longly acuminate, with indistinct costa to ca. 1/3. Seta to $20 \mathrm{~mm}$, smooth. Capsule to $2.0 \mathrm{~mm}$ long, inclined to horizontal, slightly curved. Operculum conic. Peristome complete, cilia 2, nodose. Spores 14-17 $\mu \mathrm{m}$.

In the most common expression this species is characterized by (1) robust dirty yellowgreen plants; (2) slightly falcate-secund, ovatelanceolate, gradually acuminate, and plicate leaves; (3) serrate margin; (4) costa that ends in a sharp tooth on abaxial branch leaves; (5) 50-90 $\mu \mathrm{m}$ long laminal cells; (6) \pm quadrate alar group, composed of short cells; (7) autoicous sexuality, with frequent sporophyte production; (8) smooth seta. However, the enormous variability of $B$. salebrosum sometimes makes it difficult to delimit this species from some related (B. rotaeanum at lower elevations, and $B$. erythrorrhizon in subalpine and alpine zones) and even unrelated species ( $B$. mildeanum, B. coreanum and B. falcatulum). Differences towards $B$. salebrosum are discussed under the latter five species.

Under wet conditions $B$. salebrosum may develop phenotypes with less serrulate leaves, which have wider decurrencies and more lax areolation of leaf corners, so that the angular groups becoming \pm ovate (Fig. 10). Such phenotypes can be confused with $B$. albicans (Hedw.) B. S. G., a species widely distributed in Europe and North America, but surprisingly very rare in Asia (I have seen no specimen from South Siberia or China). Brachythecium albicans is usually easy to distinguish by its $\pm \mathrm{ju}$ laceous foliage, abruptly acuminate, subentire, longly and broadly decurrent leaves, ovate alar group, composed of somewhat enlarged cells, rather short laminal cells, and an entire to weakly serrulate stem leaf margin. However in the mentioned wet habitat' phenotypes of $B$. salebrosum characters may approach this combination of $B$. albicans. In these cases the sexual condition is the best separating character ( $B$. albicans is dioicous).

Distribution: Common in boreal and north-temperate regions of Holarctic, and known also from tropical America, South Africa, Australia and New Zealand. In Altai it is common in the lower forest zone and is sporadic in the upper forest and subalpine zones. Most collections were made from rotten logs, some from soil, rocks, trunks; however collections from trunks (Salix, Betula, Sorbus) were made only at lower elevations, below $1450 \mathrm{~m}$.

Specimens examined: Adylda Creek $1100 \mathrm{~m} \mathrm{(0/}$ 2041); Ayukol $1350 \mathrm{~m}(0 / 1653), 1450 \mathrm{~m}(0 / 1646)$; Bardaky Lake, $3 \mathrm{~km}$ to the south $2100 \mathrm{~m}(11 / 14)$; Bolshoye Istyube Creek 470 m (18/134); Chulyshman against Uandu Creek mouth $1800 \mathrm{~m}$ (36/304); GornoAltaisk (SE edge) $550 \mathrm{~m}(23 / 27) ;$ Kairu Creek, $16 \mathrm{~km}$ upstream $1400 \mathrm{~m}(14 / 48 ; 14 / 61)$; Kairu Creek, 8 km upstream $1000 \mathrm{~m}(15 / 44)$; Kamga Creek, 6 km upstream $500 \mathrm{~m}(0 / 97)$; Kamga Creek, at mouth $440 \mathrm{~m}$ (Zolotukhin 20.X.1988); Karagai $440 \mathrm{~m}(0 / 286)$; Kayakkatuyarykskij Creek $1600 \mathrm{~m}$ (8/87), $1800 \mathrm{~m}$ (8/171); Kukol $1750 \mathrm{~m}(0 / 490), 1800 \mathrm{~m}(0 / 1654) ;$ Ok-Porok Creek, 1.5 km upstream $470 \mathrm{~m}(2 / 32)$; Ok-Porok Creek, at mouth 


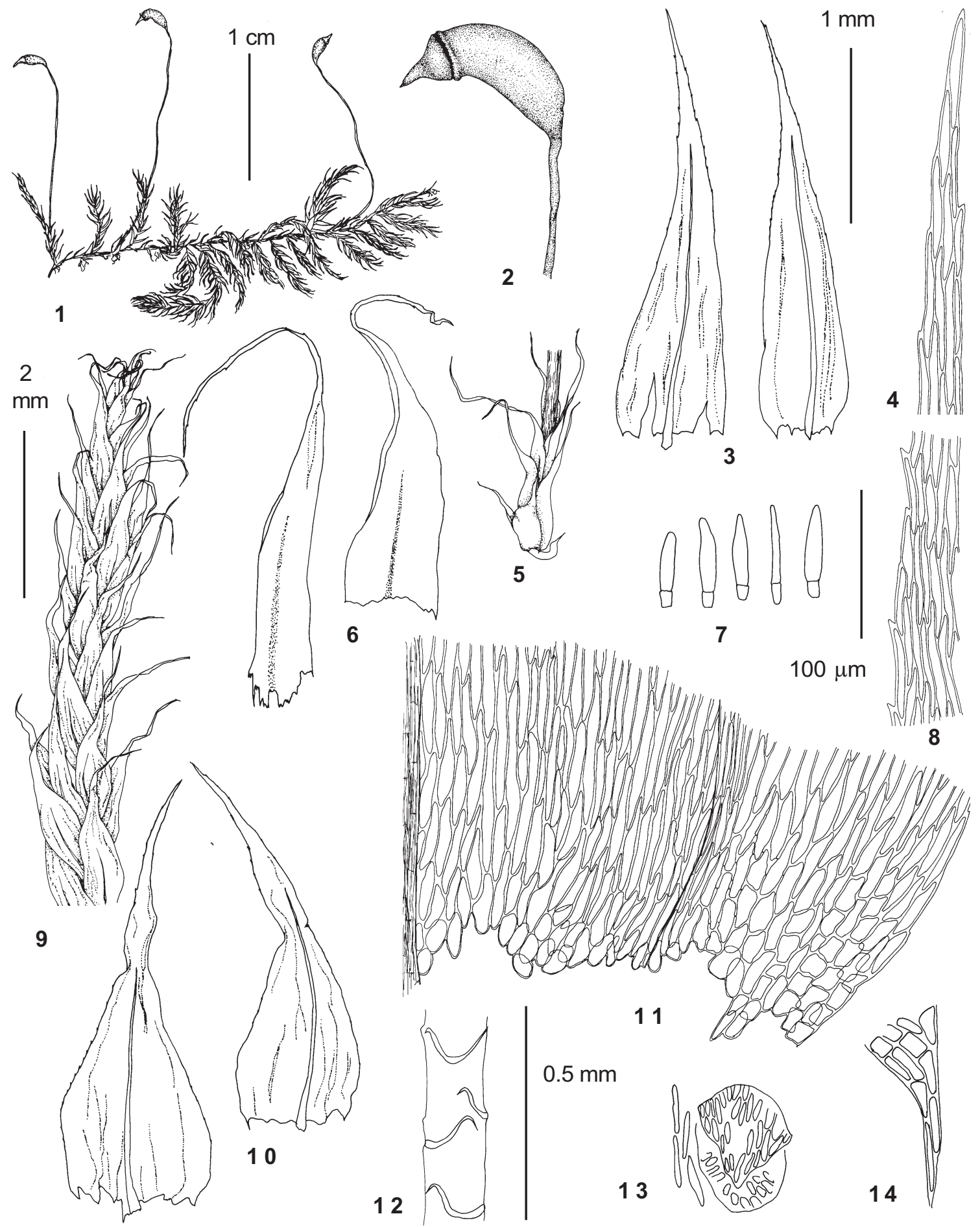

Fig. 9. Brachythecium salebrosum (Web. et Morh) B. S. G. (1-2, 5-6, 9 from Zolotukhin 20.X.1988; 3-4, 7-8, 10-14 from Ignatov 0/1646): 1 - habit; 2 - capsule; 3 - branch leaves; 4 - upper laminal cells of stem leaf; 5 - perichaetium; 6 - perichaetial leaves; 7 - axillary hairs; 8 - median laminal cells of stem leaf; 9 - upper part of stem; 10 - stem leaves; 11 - basal cells of stem leaf; 12 - stem leaf insertions; 13 - branch initial with pseudoparaphyllia; 14 - leaf decurrency. Scale bars: $1 \mathrm{~cm}$ for $1 ; 2 \mathrm{~mm}$ for 2, 5, 9; $1 \mathrm{~mm}$ for 3, 6, 10; $0.5 \mathrm{~mm}$ for $12 ; 100 \mu \mathrm{m}$ for 4, 7-8, 11, 13-14. 

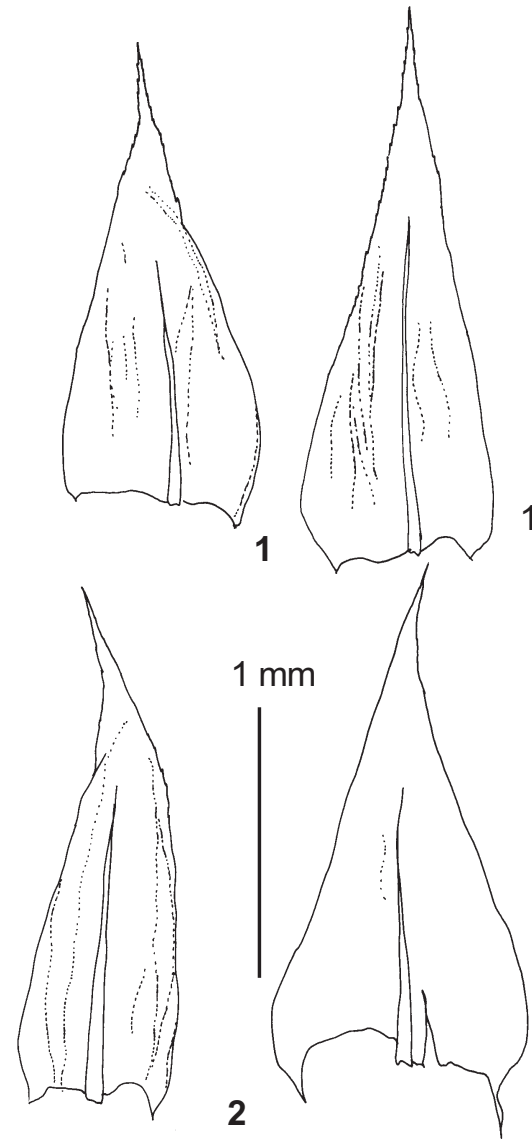
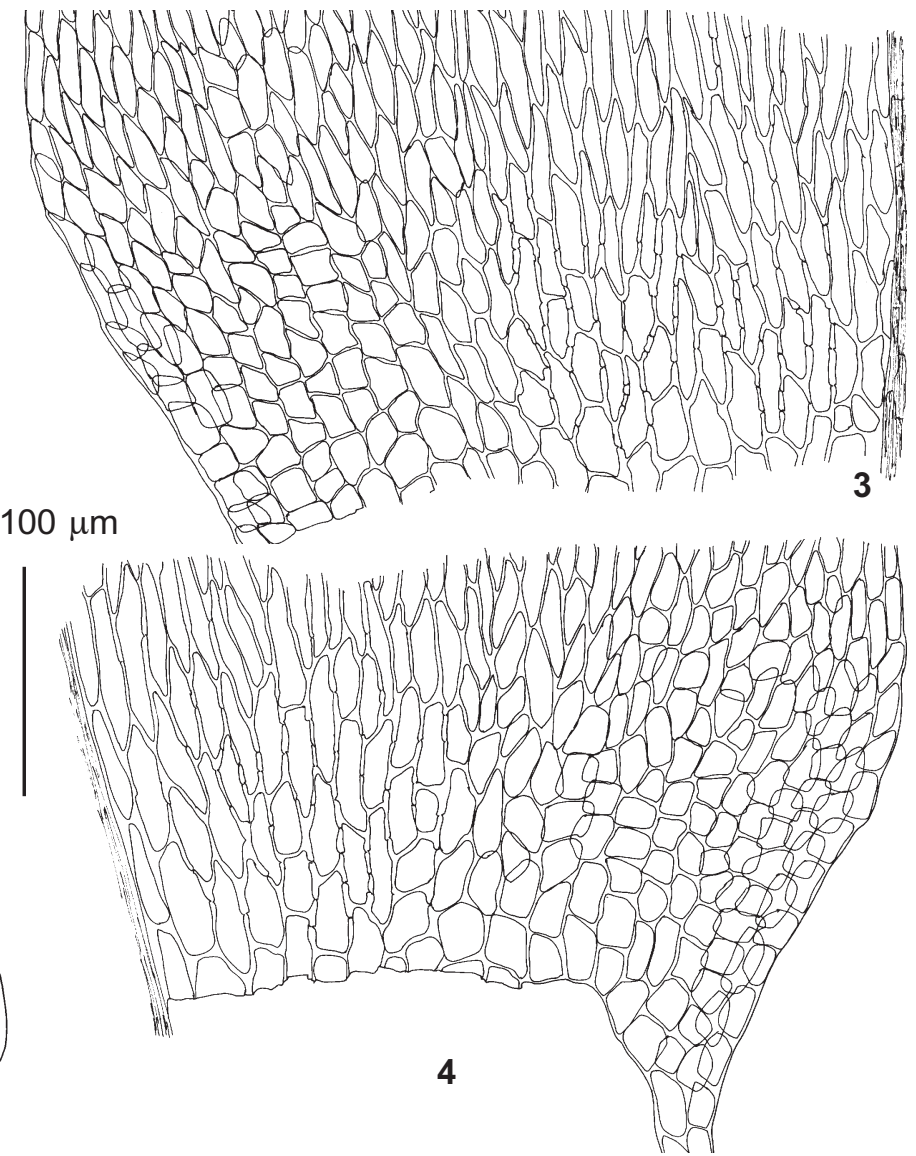

Fig. 10. Brachythecium salebrosum (Web. et Morh) B. S. G. (from Altai Territory, Barnaul, Ignatova, 1989, MHA): 1-2 - stem leaves, showing variation; 3 - basal cells of leaf "1"; 4 - basal cells of leaf "2". Scale bars: $1 \mathrm{~mm}$ for 1-2; $100 \mu \mathrm{m}$ for 3-4.

440 m (Zolotukhin 14.X.1988); Saluru Creek, in middle course $2050 \mathrm{~m}(36 / 292)$; Tabozhok Creek, $12 \mathrm{~km} \mathrm{up-}$ stream $2200 \mathrm{~m}(30 / 131)$; Tura Creek, in middle course $1400 \mathrm{~m}(28 / 6)$; Ust-Sema $400 \mathrm{~m}(24 / 72) ;$ Yailyu 450 $\mathrm{m}(0 / 1647 ; 0 / 2095 ; 1 / 51), 480 \mathrm{~m}(0 / 491)$.

Brachythecium rotaeanum De Not., Cron. Briol. Ital. 2: 19. 1867.

Fig. 11

?Brachythecium salebrosum var. capillaceum (Web. et Mohr) Lorentz, Bryol. Notizb. 66. 1865. - Hypnum salebrosum var. capillaceum Web. et Mohr, Bot. Taschenb. 313. 1807. - Brachythecium capillaceum (Web. et Mohr) Giac., Atti Ist. Bot. "Giovanni Briosi" ser. 5, 4: 268. 1947. Hypnum capillaceum (Web. et Mohr) Starke ex Brid., Muscol. Recent. Suppl. 2: 174. 1812.

Plants medium-sized to robust, pure-green with some glaucous tint, becoming whitish-yellow with age, with silky gloss. Stem rather irregularly branched, branches subjulaceous, to $8 \mathrm{~mm}$ long. Pseudoparaphyllia triangular. Axillary hairs 2-3celled, to $90 \times 7 \mu \mathrm{m}$, apical cell to $75 \mu \mathrm{m}$ long. Stem leaves to $2.0 \times 0.7 \mathrm{~mm}$, lanceolate, gradually acumi- nate, widest at about $1 / 5$ of leaf length; concave, plicate; at base shortly decurrent; costa reaching 0.6-0.75 of leaf length, $40-55 \mu \mathrm{m}$ wide at base; margin weakly serrulate throughout. Median laminal cells $45-100 \times 6.5-8(5-6 / 1.0-2.0) \mu \mathrm{m}$; towards base cells wider in 5-8 rows, forming laxly areolated area; in leaf corner subquadrate cells $(12-15 \mu \mathrm{m}$ wide) forming indistinctly delimited group; widest cells are in (1)2(3) rows at $1 / 3-1 / 5$ of way from margin to costa (in between the juxtacostal and alar cells). Branch leaves narrower, more serrate, with costa ending in indistinct spine. Autoicous, rarely polyoicous. Perichaetial leaves longly acuminate. Seta to $10 \mathrm{~mm}$, smooth. Capsule $1.5 \mathrm{~mm}$ long, erect below, usually slightly inclined above, rarely strongly inclined to horizontal. Operculum conic. Peristome complete; cilia 2, nodose. Spores 16-19 $\mu \mathrm{m}$.

Specimens referred here to this species are partly autoicous, partly polyoicous (constant within single collections). Some authors used the suberect capsule as the main diagnostic character of this species. However it was found to 


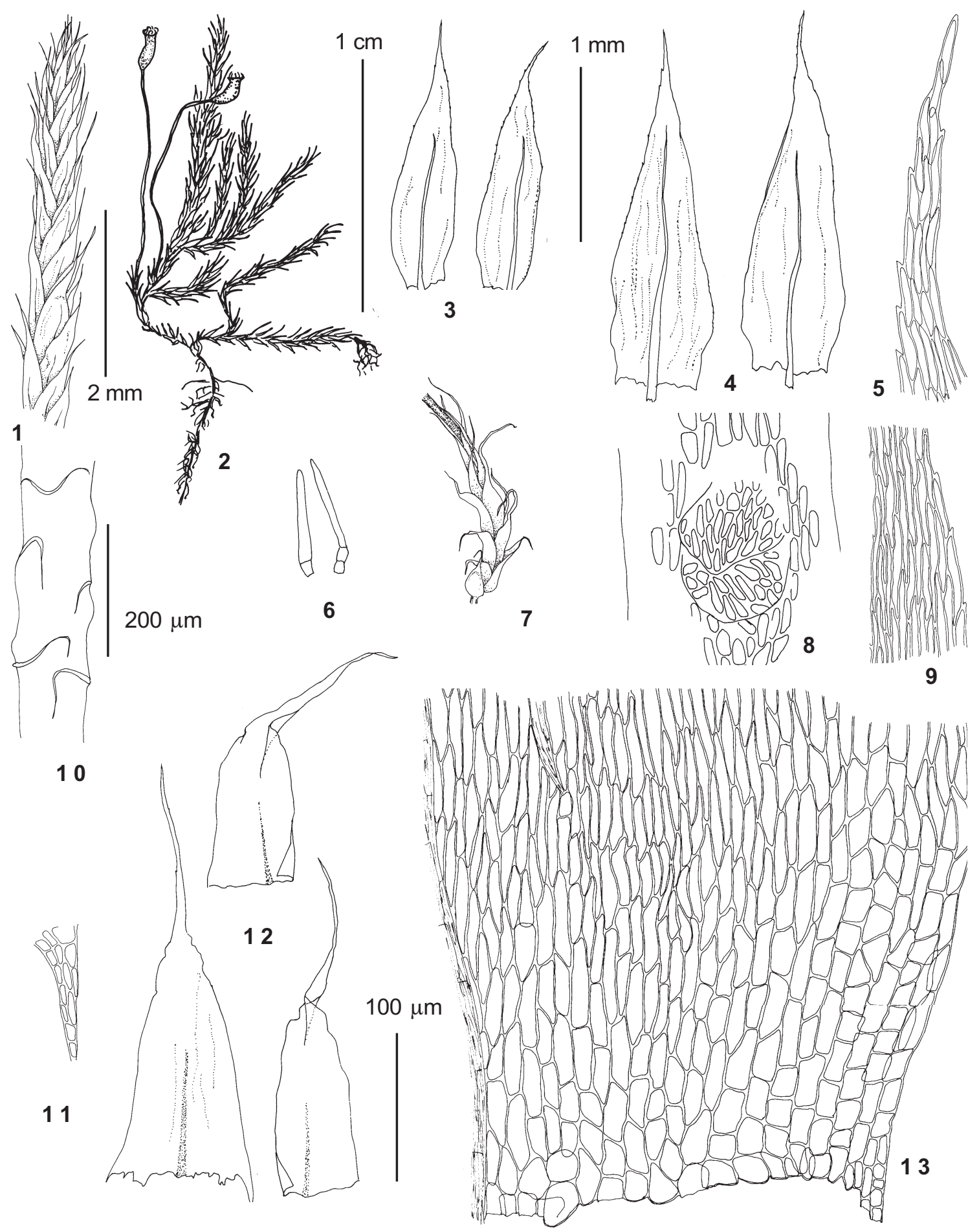

Fig. 11. Brachythecium rotaeanum De Not. (from Ignatov 0/159): 1 - upper part of stem; 2 - habit; 3 - branch leaves; 4 - stem leaves; 5 - upper laminal cells of stem leaf; 6 - axillary hairs; 7 - perichaetium; 8 - branch initial with pseudoparaphyllia; 9 - median laminal cells of stem leaf; 10 - stem leaf insertions; 11 - leaf decurrency; 12 perichaetial leaves; 13 - basal cells of stem leaf. Scale bars: $1 \mathrm{~cm}$ for $2 ; 2 \mathrm{~mm}$ for 1,$7 ; 1 \mathrm{~mm}$ for 3-4, $12 ; 200 \mu \mathrm{m}$ for 10 ; $100 \mu \mathrm{m}$ for $5-6,9,11,13$. 
be unstable. Although most specimens have slightly inclined capsules, in a few collections they are more strongly inclined.

This species has a very peculiar appearance and color, and after some training it becomes easy to recognize in the field. The diagnostic characters of $B$. rotaeanum are as follows: (1) leaves straight, gradually long acuminate, concave, shoots julaceous, somewhat resembling $B$. albicans; (2) leaf margin serrulate; (3) extensive portion of basal leaf laxly areolate with \pm square alar group and more transparent zone at $1 / 3$ $1 / 5$ of way from margin to costa; (4) autoicous or polyoicous sexuality and abundant sporophyte production; (5) capsule usually less inclined than in other Altaian species.

Brachythecium rotaeanum resembles $B$. albicans in its julaceous foliage, but differs from the latter in having gradually (not abruptly) acuminate leaves, straight (not flexuose) leaf acumina, quadrate (not ovate) groups of alar cells, short (not long) leaf decurrencies, autoicous or polyoicous (not dioicous) sexual condition, suberect (not inclined to horizontal) capsules, and characteristically green (not pale-yellow) color.

Brachythecium rotaeanum also resembles the European B. glareosum (though reported from Asia, all so-named collections from this continent which I have seen belong to other species). Similarities with $B$. glareosum include straight, concave and plicate leaves and rather similar basal areolation, including alar group of moderately small cells and more transparent group between juxtacostal and alar cells. However B. glareosum is dioicous, its plants are more robust and coarse, of a dirty yellowgreen color, the leaf acumen in dry condition more spreading, and the leaf margin is usually less serrate to subentire.

Many characters of $B$. rotaeanum are the same as in $B$. salebrosum, and it is often considered a variety of the latter, $B$. salebrosum var. capillaceum. However B. rotaeanum has a very peculiar habit and color, always straight leaves, more lax basal areolation than $B$. salebrosum and a suberect capsule. In Altai it often grows in the same habitats as B. salebrosum, but usually there are no problems to distinguish them. When they grow together (on trunks of Salix, Populus, etc.) two species look strikingly different. Some phenotypes of $B$. sale- brosum have straight leaves (when growing on exposed rocks, on strongly disturbed soil, etc.), but the leaves are more strongly serrate, and narrow laminal cells reach the leaf base.

European and American B. laetum (Brid.) B. S. G. (=B. oxycladum auct.) is similar to $B$. rotaeanum in the suberect capsule, and Robinson (1962) suggested their close relationship. Crum \& Anderson (1981) did not confirm this, since the basal areolation of these species is different. The latter concept agrees with my observations on Altaian material. Brachythecium laetum differs from $B$. rotaeanum in its yellow-green color, dioicous sexual condition, and narrow cells across the whole base, so that the leaf base looks opaque.

Distribution of Brachythecium rotaeanum is very imperfectly known - I have seen collections identical to Altaian material from Eastern North America, Romania, Northern European Russia, the Ural Mountains, other parts of South Siberia, Russian Far East, and North-East China. I have not been able to check the type of $B$. rotaeanum, and my choice of this name is based on the descriptions and illustrations of Crum \& Anderson (1981) and Takaki (1955b). Additional studies of the types of $B$. rotaeanum and Hypnum salebrosum var. capillaceum are necessary. In any case, in Europe this is not a widespread taxon. Düll (1985) confirmed its occurrence (as B. capillaceum) only for Romania, Hungary and Poland.

In Altai B. rotaeanum occurs at lower to middle elevations, growing on trunks of Salix, Populus, more rarely on Betula, and occasionally on rocks and rotten logs, in exposed to moderately shady habitats.

Specimens examined: Askat $350 \mathrm{~m}$ (Zerov 12.VIII. 1940 LB!); Ayukol $1000 \mathrm{~m}$ (0/3003); Bele $500 \mathrm{~m}(0 /$ 75); Chemal $450 \mathrm{~m}(29 / 25)$; Chichelgan $450 \mathrm{~m}$ (Zolotukhina 30.3.1988); Chiri Creek, $0.5 \mathrm{~km}$ upstream $450 \mathrm{~m}$ (17/83; 17/90); Chulcha River, in middle course 1000 m $(9 / 137 ; 9 / 158 ; 9 / 159 ; 9 / 18 ; 9 / 73 ; 9 / 91) ;$ Der bogach $450 \mathrm{~m}(0 / 3002)$; Edikhta Creek $800 \mathrm{~m}$ (34/ 163); Gorno-Altaisk 400 m (35/39); Karagai $440 \mathrm{~m}$ (0/267; 0/287); Klyk Pass 700 m (0/3004); Kobukhta $750 \mathrm{~m}(0 / 230)$; Kyga River, $1 \mathrm{~km}$ upstream $450 \mathrm{~m}$ (0/ 1691); Kyrsai $450 \mathrm{~m}$ (Bardunov 6.7.1966); Srednij Shaltan Creek 640 m (0/3005); Telezkoye Lake 450 m (34; Korotkov 11.7.1958); Ust-Sema $450 \mathrm{~m}$ (24/39); Yailyu $450 \mathrm{~m}(0 / 3001 ; 1 / 11 ; 1 / 37 ; 1 / 54), 550 \mathrm{~m}(0 / 1644)$.

Brachythecium turgidum (Hartm.) Kindb., Vidensk. Meddel. Dansk Naturhist. Foren. Kjobenhavn ser. 4, 9: 294. $1888 . \quad$ Fig. 12

Hypnum salebrosum var. turgidum C. J. Hartm., Handb. Skand. Fl. (ed. 3) 3: 309. 1838.

Plants robust, yellow-green to golden-yellow. Stems sparsely branched, sometimes almost un- 


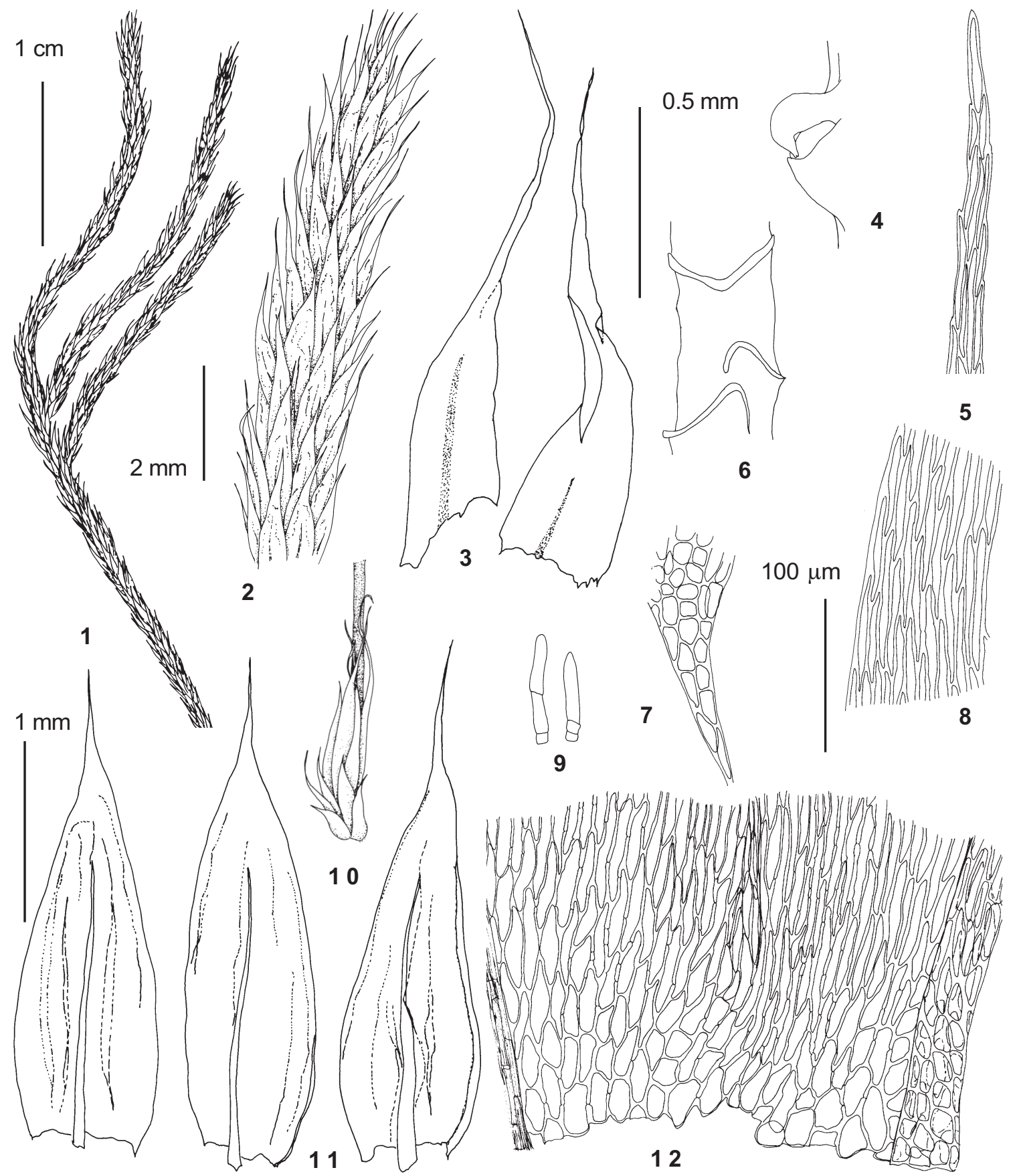

Fig. 12. Brachythecium turgidum (Hartm.) Kindb. (from Ignatov 31/291): 1 - habit; 2 - upper part of stem; 3 perichaetial leaves; 4 - branch initial with pseudoparaphyllia; 5 - upper laminal cells of stem leaf; 6 - stem leaf insertions; 7 - leaf decurrency; 8 - median laminal cells of stem leaf; 9 - axillary hairs; 10 - perichaetium; 11 - stem leaves; 12 basal cells of stem leaf. Scale bars: $1 \mathrm{~cm}$ for $1 ; 2 \mathrm{~mm}$ for 2,$10 ; 1 \mathrm{~mm}$ for 3,$11 ; 0.5 \mathrm{~mm}$ for 4, 6; $100 \mu \mathrm{m}$ for $5,7-9,12$.

branched, branches subjulaceous, to $15 \mathrm{~mm}$ long. Pseudoparaphyllia triangular. Axillary hairs 3-celled, to $90 \times 9-11 \mu \mathrm{m}$, apical cell to $60 \mu \mathrm{m}$ long. Stem leaves densely imbricate, straight, $3.0 \times 1.1 \mathrm{~mm}$, lanceolate to broadly-lanceolate, gradually to abruptly acuminate, widest at $1 / 3-1 / 5$ of leaf length; concave, strongly plicate; at base shortly decurrent; costa reaching 0.6-0.7 of leaf length, 40-75 $\mu \mathrm{m}$ wide at base; margin subentire, often recurved. Median laminal cells $80-140 \times 8-11(5.5-8 / 2.0-3.0) \mu \mathrm{m}$, in leaf corners subquadrate cells forming indistinct square group, reaching $1 / 3$ of distance to costa 


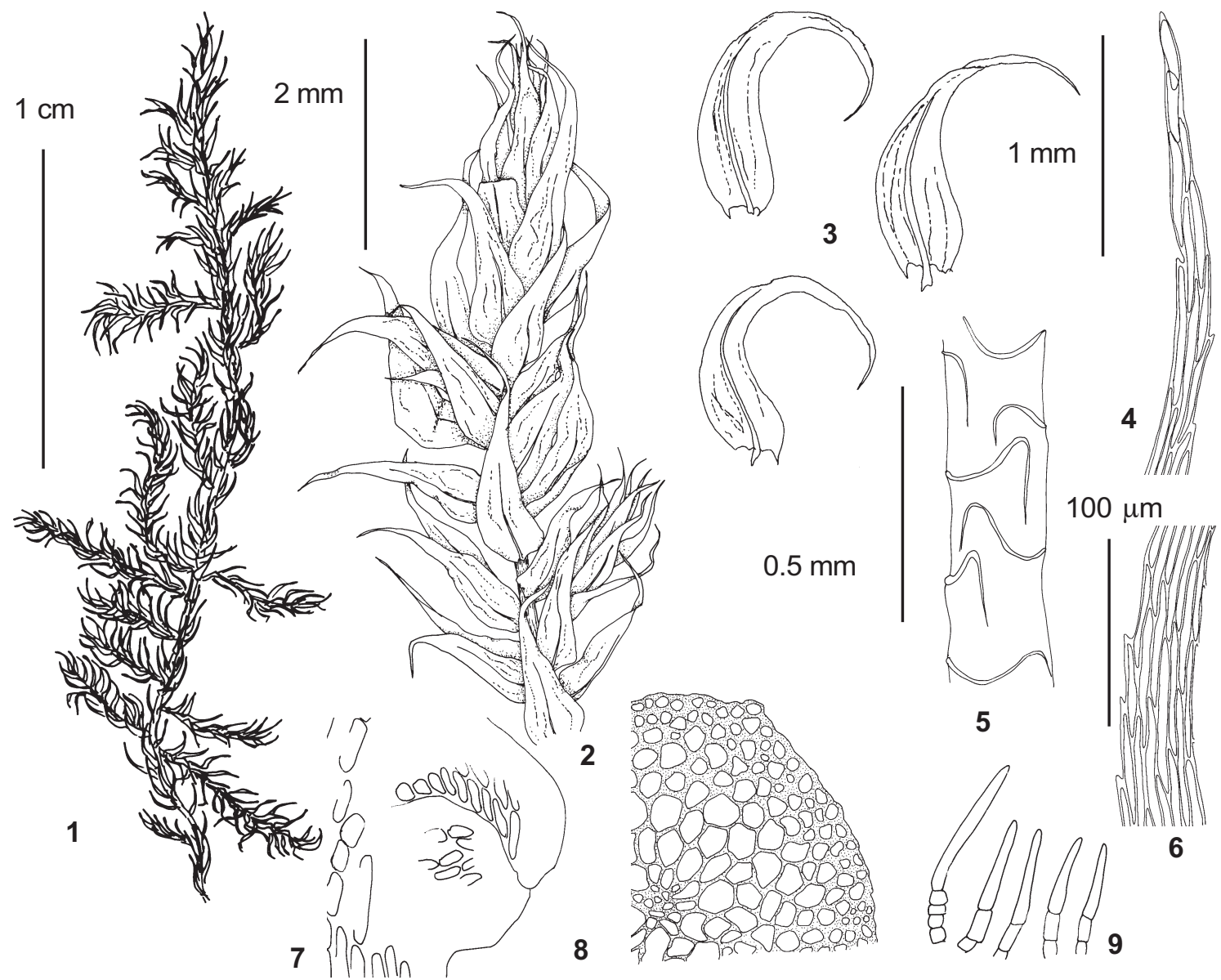

Fig. 13. Brachythecium erythrorrhizon B. S. G. var. asiaticum var. nov. (from Ignatov 0/1656): 1 - habit; 2 upper part of stem; 3 - branch leaves; 4 - upper laminal cells of stem leaf; 5 - stem leaf insertions; 6 - median laminal cells of stem leaf; 7 - branch initial with pseudoparaphyllia; 8 - stem transverse section; 9 - axillary hairs. Scale bars: $1 \mathrm{~cm}$ for $1 ; 2 \mathrm{~mm}$ for $2 ; 1 \mathrm{~mm}$ for 3,$8 ; 0.5 \mathrm{~mm}$ for $5 ; 100 \mu \mathrm{m}$ for $4,6-9$.

(sometimes this group is transversely ovate). Branch leaves narrower; costa ending in short spine. Autoicous. Perichaetial leaves short, abruptly acuminate. Seta smooth, ca. $8 \mathrm{~mm}$ (found in one specimens and maybe imperfectly developed). Capsule inclined (only premature capsules were found in one collection from Altai; other specimens were all sterile despite presence of both perigonia and perichaetia).

Brachythecium turgidum is peculiar in: (1) robust, rarely branching plants; (2) dense foliage (about as in Homalothecium philippeanum); (3) straight, longly and gradually acuminate, deeply plicate leaves with subentire margin; (4) very thick walls of laminal cells; (5) small opaque groups of subquadrate alar cells; (6) autoicous sexuality (but rare sporophyte production). The differences between $B$. mildeanum are discussed under the latter.

Distribution: Arcto-alpine species. In Eurasia outside Arctic B. turgidum has been reported from boreal regions of Western Europe and from highmountains of Central Europe, South Siberia and Middle Asia. In Altai B. turgidum occurs mostly in the South-East (close to Mongolia), at 2300 to $2800 \mathrm{~m}$; on soil in mountain tundras and on rock outcrops.

Specimens examined: Dzhulukul Lake $3000 \mathrm{~m}$ (Zolotukhin 30.VI.1986); Kokkul Lake 2300 m (33/30; 33 / 32); Saluru Creek, upper course $2250 \mathrm{~m}$ (36/152); Tabozhok Peak $2350 \mathrm{~m}$ (31/291), $2700 \mathrm{~m}(31 / 296 ; 31$ ) 299; $31 / 318), 2750 \mathrm{~m}(31 / 294), 2800 \mathrm{~m}$ (31/290; $31 /$ 300); Wasserscheide Aspalty \& Kadrin $2150 \mathrm{~m}$ (28.VIII.1914 Grano H-BR).

Brachythecium erythrorrhizon B.S.G., Bryol. Eur. 6: 18. pl. 547. 1853. Fig. 13, 14 ssp. asiaticum Ignatov ssp. nov.

A subspecies typica habitu robustiore, foliis caulinis $1.9-2.4$ x $0.6-1.0 \mathrm{~mm}$ nec $1.3-1.7 \mathrm{x}$ 0.5-0.7, caule folioso 1.1-1.9 nec 0.7-1.2 lato differt. 


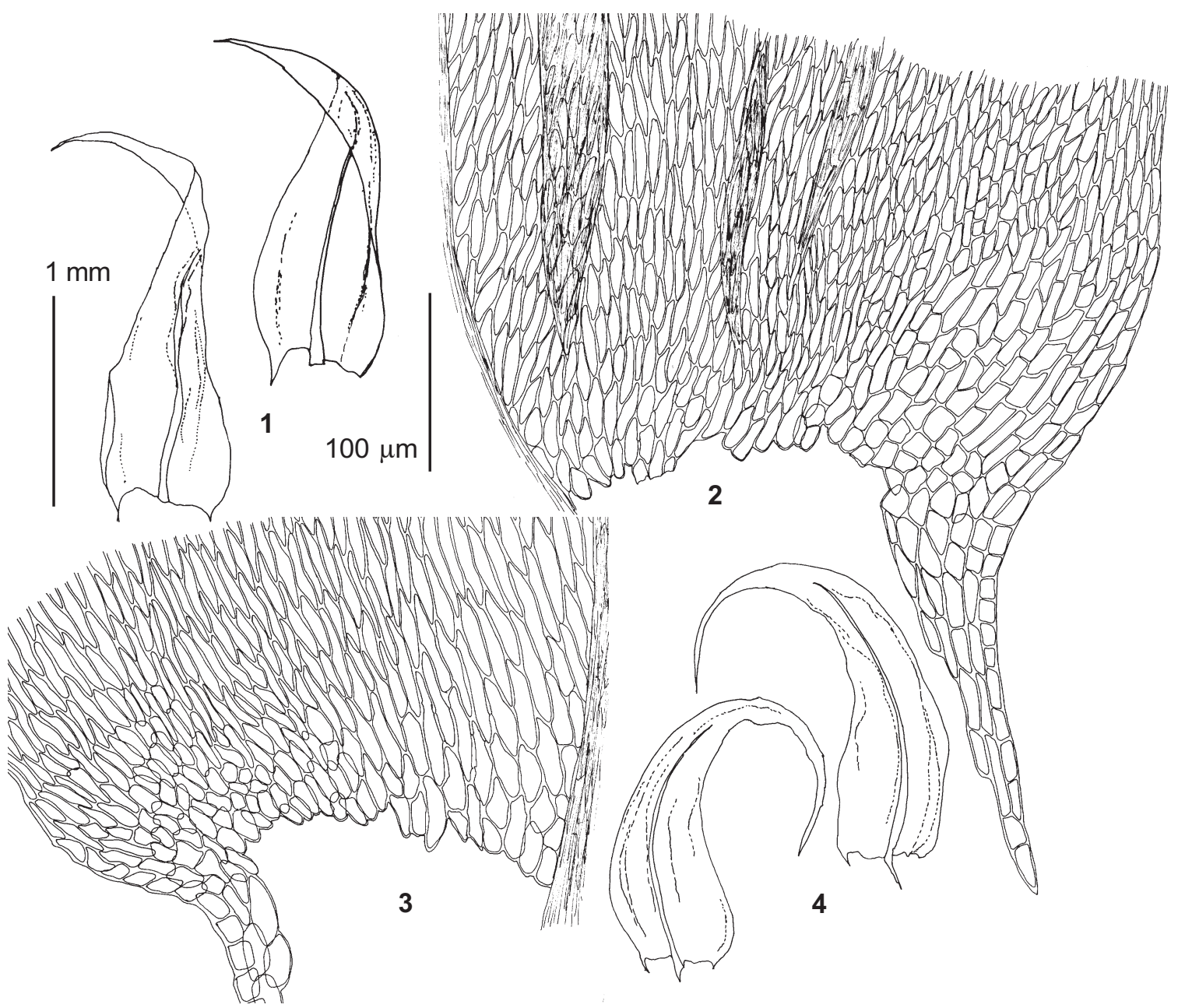

Fig. 14. Brachythecium erythrorrhizon B. S. G. ssp. asiaticum var. nov. (1-2 - from Ignatov $7 / 1$; 3-4 - from Ignatov 0/1656): 1, 4 stem leaves; 2-3 - basal cells of stem leaves. Scale bars: $1 \mathrm{~mm}$ for 1, 4; $100 \mu \mathrm{m}$ for 2, 3.

Holotype: Altai Mts., $50^{\circ} 25^{\prime}-89^{\circ} 3^{\prime}$, Ayulyuyuzyuk Creek, $2500 \mathrm{~m}$ alt., on moderately dry rocks in open tundra. 16.VI.1989. M. Ignatov 0/1656 (MHA).

Plants green. Stem \pm regularly pinnately branched, branches to $6 \mathrm{~mm}$ long. Pseudoparaphyllia triangular. Axillary hairs 3-4(5)-celled, 60-110 x 8-9 $\mu \mathrm{m}$, apical cell 30-70 $\mu \mathrm{m}$ long. Stem leaves moderately densely arranged, \pm falcate, $2.3 \times 0.6 \mathrm{~mm}$, lanceolate, gradually acuminate, widest at ca. 1/7 of leaf length; strongly concave and distinctly plicate; at base longly and broadly decurrent; costa reaching $0.6-0.75$ of leaf length, $40-50(70) \mu \mathrm{m}$ wide at base; margin serrulate throughout to subentire below, often recurved from leaf base to base of acumen. Median laminal cells 40-90 x 7-10 (5-8/1.52.5) $\mu \mathrm{m}$; towards base in 3-4 rows shorter, in leaf corners subquadrate cells forming quadrate groups, reaching $1 / 3$ of distance to costa or sometimes alar cells enlarged and forming \pm ovate group. Branch leaves similar in shape, but narrower; costa ending in indistinct spine. Gametangia and sporophytes not seen in Altaian collections. [Dioicous. Seta smooth. Peristome complete, cilia 1-2, nodose].

This subspecies differs from the type subpecies in larger plants with stem leaves $1.9-2.4 \times 0.6-1.0$ $\mathrm{mm}$ (not $1.3-1.7 \times 0.5-0.7 \mathrm{~mm}$ ) and shoot width 1.1-1.9, not $0.7-1.2 \mathrm{~mm}$.

The fact that in most of Russian territory B. erythrorrhizon is larger than in Europe was noted by Abramova \& al. (1961), who considered these plants to belong to B. erythrorrhizon var. uralense (Gorodk.) Podp. $(=B$. uralense Gorodk.). However the type of Brachythecium uralense belongs to another little known species - Lescuraea secunda.

Lescuraea Secunda H. Arnell, Rev. Bryol. 25: 9. 1898. Holotype: Altai, in monte Borus 20.VII.1888 Argunow (S!). - Pseudoleskea secunda (H. Arnell) Broth., Nat. Pfl., ed. 2, 11: 307. 1925. 
Brachythecium uralense Gorodk., Trudy Bot. Muz. 24: 56. f. 1. 1932. syn. nov. Lectotype: “Полярный Урал, бассейн р. Сыни, верховья р. Колокольня, субальпийский луг. 14.VIII. 1926. Городков” [Subarctic Ural, Synya River Basin, upper course of Kolokolnya Creek, subalpine meadow. 14.VIII.1926 Gorodkov] (LE!; isolectotypes S!, H!); Syntype: Полярный Урал, верховья Нырдомен, травяная лужайка с Juniperus на склоне к ручью 7.VIII.1926. Городков [Subarctic Ural, upper course of Nyrdomen River, grassland with Juniperus on slope to a stream. 7.VIII.1926 Gorodkov] (LE!; isosyntypes S!, H!). - Brachythecium erythrorrhizon var. uralense (Gorodk.) Podpera, Consp. Musc. Eur. 608. 1954.

However the statement of Abramova \& al. (1. c.) remains valid: in Asian Russia there is a widely distributed moss close to European B. erythrorrhizon, differing from the latter mainly in its considerably larger size. Its similarities to $B$. erythrorrhizon include: (1) \pm falcate, strongly concave and plicate leaves; (2) relatively short and wide median laminal cells; (3) weakly serrulate leaf margins; (4) long and broad leaf decurrency; (5) dioicous sexual condition. The differences between the two are mainly quantitative:

Shoot width, mm ssp. erythrorrhizon ssp. asiaticum

-including acumina (0.7)1.0-1.5(2.0) (1.5)2.0-3.0

- excluding acumina $\quad 0.7-1.2 \quad 1.1-1.9$

Stem leaf, $\mathrm{mm} \quad 1.5 \times 0.65 \quad 2.3 \times 0.6-1.0$

Hedenäs (1996) lecotypifyed B. erythrorrhizon, and provided a careful comparison with B. salebrosum and B. albicans (and some other less closely related species). The differences between B. erythrorrhizon and the former include (1) smaller size; (2) more falcate and more plicate leaves; (3) shorter and narrower cells in stem leaves; (4) dioicous sexual condition. Characters 2, 3 and 4 are valid for distinguishing of B. erythrorrhizon $\mathrm{ssp}$. asiaticum from $B$. salebrosum. Some other differences are not hundred-percent reliable, but are mostly useful for the recognition of $B$. erythrorrhizon ssp. asiaticum: (5) green to whitish-green color of the plants; (6) usually weakly serrulate leaves; (7) long and broad leaf decurrencies. The latter character is variable in Altaian plants - more narrow-leaved phenotypes have rather small alar groups and their recognition is possible by means of their strongly falcate leaves. In broad-leaved phenotypes the leaves are less strongly falcate, and important for their recognition are the broadly decurrent leaves with extensive alar groups (Fig. 14).

The characteristics of the alar groups and also characters 4 and 7 show the affinity of $B$. erythrorrhizon to $B$. albicans. However the latter differs in (1) its almost always ovate alar group; (2) its more concave leaves, which are less plicate and more abruptly contracted into acumen; (3) its straight branch leaves (Hedenäs, 1996). Important characters of $B$. albicans also include the julaceous foliage of shoots, the pale-stramineous color, and the more or less entire basal part of stem leaves.

The differentiation from B. mildeanum are discussed under that species.

Distribution: This species is distributed in Arctic and neighboring territories of the North, and mountain areas of the Northern part of Holarctic (Central Europe, Caucasus, Altai, NW China, mountains of South and East Siberia and Russian Far East, etc.). The type subspecies has a European distribution, while described subspecies is known from the Asian Arctic, the Ural Mountains and mountains of South Siberia (Altai and Sayans), and the northern part of the Russian Far East (Khabarovsk Territory). In Altai $B$. erythrorrhizon ssp. asiaticum occurs mainly in the subalpine to lower alpine belt in tall-herb meadows and herbaceous variants of Betula nana shrubs, on soil and rocks (often with Rhytidiadelphus squarrosus, Brachythecium ornellanum, etc.).

Specimens examined: Ak-Turu Creek, upper course 2600 m (Bardunov 19.VII.1966); Ayulyuyuzyuk Creek $2500 \mathrm{~m}(0 / 1656)$; Bardaky Lake, $3 \mathrm{~km}$ to the south 2100 $\mathrm{m}(11 / 3)$; Bayas Lake $1850 \mathrm{~m}(0 / 1653), 1950 \mathrm{~m}(0 /$ 1655; 0/1668), $2050 \mathrm{~m}$ (0/1657); Chainary Creek, upper course $1800 \mathrm{~m}(34 / 203)$; Kairu Creek, $16 \mathrm{~km}$ upstream $1400 \mathrm{~m}$ (14/29); Kairu-Bazhi Peak $2050 \mathrm{~m}$ (13/ 114; 13/115; 13/24), 2150 m (13/28); Karakol Lakes 1900 m (28/75; 38/93); Kayakkatuyarykskij Creek 1920 m (3/273), $2350 \mathrm{~m}$ (7/1); Saluru Creek, in middle course 2050 m (36/415); Seminskij Pass 1700 m (Vysozkaya 4227, 4252 LB!); Tabozhok Peak 2750 m (31/297); Toshkalykaya Peak $2500 \mathrm{~m}$ (Zolotukhin 14.VII.1990).

Brachythecium buchananii (Hook.) Jaeg., Ber. Thaetigk. St. Gallischen. Naturwiss. Ges. 1876-77: 341. 1878.

Figs. 15, 16

Hypnum buchananii Hook., Trans. Linn. Soc., 9: 320.1808.

Plants slender to medium-sized, green or yellowgreen, often pale-green to pale-stramineous. Stem to 2-3 cm long, \pm regularly pinnate branched, \pm flexuose, branches with subjulaceous foliage, to $4 \mathrm{~mm}$ long. 


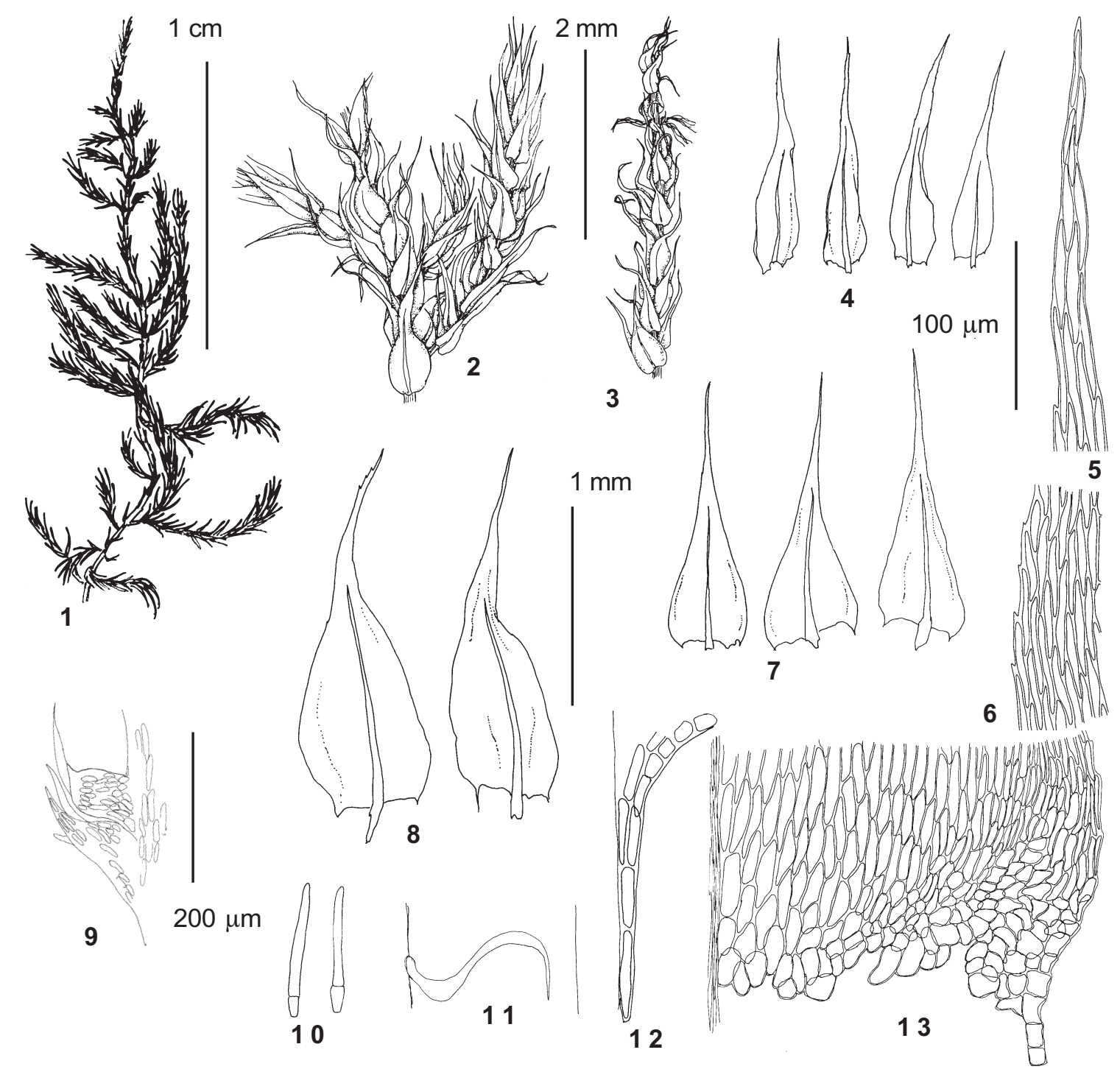

Fig. 15. Bachythecium buchananii (Hedw.) Jaeg. (from Ignatov 29/29): 1 - habit; 2 - part of stem with branches; 3 - upper part of branch; 4 - branch leaves; 5 - upper laminal cells of stem leaf; 6 - median laminal cells of stem leaf; 7-8 - stem leaves from different shoots, showing variations; 9 - branch initial with pseudoparaphyllia; 10 axillary hairs; 11 - stem leaf insertion; 12 - leaf decurrency; 13 - basal cells of stem leaf. Scale bars: $1 \mathrm{~cm}$ for $1 ; 2$ $\mathrm{mm}$ for $2-3 ; 1 \mathrm{~mm}$ for $4,7-8 ; 200 \mu \mathrm{m}$ for 9,$11 ; 100 \mu \mathrm{m}$ for $5-6,10,12-13$.

Pseudoparaphyllia lanceolate. Axillary hairs 2-4celled, to $60-80 \times 6-9 \mu \mathrm{m}$, apical cell 50-65 $\mu \mathrm{m}$ long. Stem leaves erect-spreading, to $1.8 \times 0.6 \mathrm{~mm}$, lanceolate to ovate-lanceolate, gradually to abruptly acuminate; strongly concave and moderately plicate; at base rather shortly narrowly decurrent; costa reaching $0.55-0.75$ of leaf length, $30-50 \mu \mathrm{m}$ wide at base; margin subentire to serrulate above, sometimes serrulate throughout. Median laminal cells $40-90$ x 5.57.5[9] (4.0-7.0/1.5-2.0) $\mu \mathrm{m}$ (at $1 / 2-2 / 3$ of leaf length), cells in lower concave part of leaf wider and laxer, these cells reach leaf base; in leaf corner subquadrate cells forming \pm quadrate group which is indistinctly delimited from surrounding cells. Branch leaves shorter and narrower, lanceolate, with shorter laminal cells and more strongly serrulate margin; costa ending in weak, narrow spine. Dioicous. Gametangia and sporophytes were not seen in Altaian populations. [Seta smooth, operculum high-conic].

Brachythecium buchananii differs from the other Altaian species of the genus in its (1) relatively small size (about that of $B$. populeum); (2) \pm flexuose stem; (3) usually pale stramineous color (in deep shade rich green); (4) costa ending above mid-leaf; (5) lax areolation in lower leaf; (6) narrow, lanceolate 


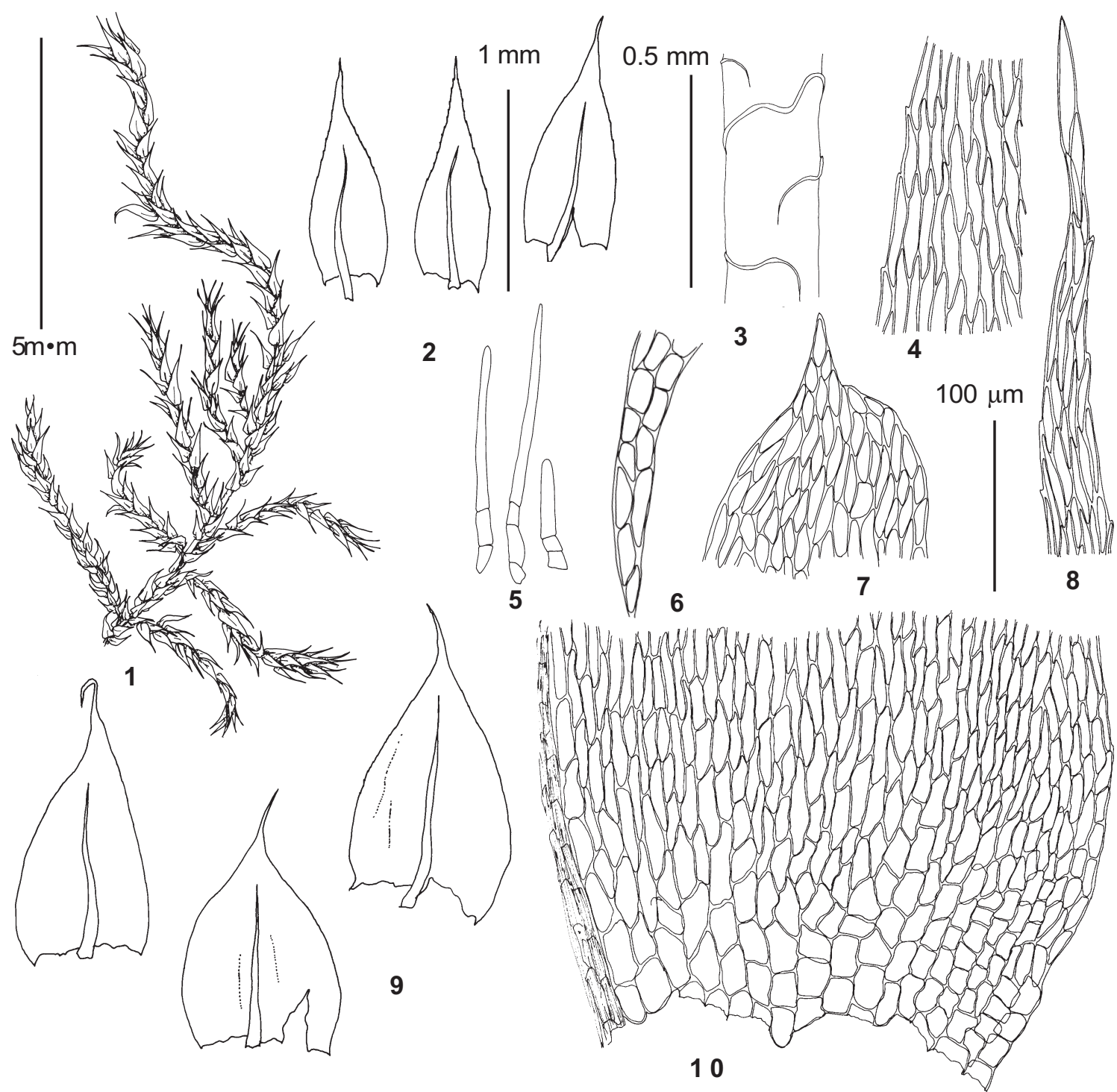

Fig. 16. Bachythecium buchananii (Hedw.) Jaeg., short-leaved phenotype (from Ignatov 0/1667): 1 - habit; 2 branch leaves; 3 - stem leaf insertions; 4 - median laminal cells of stem leaf; 5 - axillary hairs; 6 - leaf decurrency; 7 - pseudoparaphyllium; 8 - upper laminal cells of stem leaf; 9 - stem leaves; 10 - basal cells of stem leaf. Scale bars: $5 \mathrm{~mm}$ for $1 ; 1 \mathrm{~mm}$ for 2,$9 ; 0.5 \mathrm{~mm}$ for $3 ; 100 \mu \mathrm{m}$ for $4,5-8,10$.

pseudoparaphyllia. This species is one of the most variable in the genus, and even in Altai where it is a rare species, $B$. buchananii is represented by different phenotypes. Plants of mesic habitats (growing among other mosses on willow trunks, etc.) are medium-sized, with longly acuminate, subentire leaves, narrow median laminal cells, 5-6 $\mu$ m wide, broadly ovate base with well-delimited groups of small alar cells. Plants growing on dry rock outcrops (Fig. 16) are smaller, have shorter leaves (to $1.2 \mathrm{~mm}$ long), with more strongly serrate margin, with wider laminal cells, and more extensive alar groups. Some phenotypes from dry rocks have narrow leaves with strikingly long acumina and the basal cells homogeneous throughout. However, since there are plants intermediate between all these phenotypes they are here referred to one species.

Distribution: One of the most common species of the genus in China, Japan, and the Himalayan region, reaching westward to Pakistan, eastward to the Phili ppines, and southwards to Vietnam. In Russia its northern limit is at $51-52^{\circ} \mathrm{N}$ in the Far East and in the mountains of South Siberia. In Altai it grows at lower elevations, on exposed to moderate- 
ly shaded and usually \pm dry rocks, more rarely on fallen logs, Salix trunks and soil.

Specimens examined: Chemal $450 \mathrm{~m}(29 / 29)$; Chiri $450 \mathrm{~m}(0 / 1648)$; Chiri Creek, $0.5 \mathrm{~km}$ upstream $450 \mathrm{~m}$ (17/7); Derbogach 440 m (0/1651); Edikhta Creek 1100 m (34/165); Elekmonar Creek, 8 km upstream $800 \mathrm{~m} \mathrm{(26/)}$ 65); Kairu Creek, 8 km upstream $1000 \mathrm{~m}$ (15/140; 15/47); Karagai 440 m (Zolotukhin 12.VIII. 1988; 0/265), $500 \mathrm{~m}$ (Zolotukhin 10.VIII.1988); Kobukhta 550 m (0/1667), 600 $\mathrm{m}(0 / 243)$; Kumzir $450 \mathrm{~m}(20 / 14 ; 20 / 18)$; Maima $350 \mathrm{~m}$ (35/46); Malyi Yaloman Creek, 7 km upstream $1000 \mathrm{~m}$ (25/15; 25/64); Ok-Porok Creek, 1.5 km upstream $470 \mathrm{~m}$ (2/26; 2/32a; 2/4); Ok-Porok Creek, at mouth $440 \mathrm{~m}(0 /$ 1652); Ust-Sema $330 \mathrm{~m}(24 / 47), 400 \mathrm{~m}(24 / 71), 450 \mathrm{~m}$ (24/117; 24/154; 24/83); Yailyu $440 \mathrm{~m}(0 / 1650), 450 \mathrm{~m}$ (0/1649;1/12;1/2;1/85); Yurga $440 \mathrm{~m}(21 / 15)$.

\section{Sect. Brachythecium}

Plants robust, rarer medium-sized; stem leaves ovate-lanceolate to broadly-lanceolate, slightly to strongly plicate; laminal cells relatively broad, thinwalled; alar cells in leaf corners enlarged; seta mammillose to smooth; capsule inclined to horizontal.

Brachythecium mildeanum (Schimp.) Schimp. ex Milde, Bot. Zeitung (Berlin) 20: 452. 1862.

Fig. 17, 18

Hypnum mildeanum Schimp., Syn. Musc. Eur. 694. 1860

Plants deep green, yellow to yellow-brownish. Stem \pm regularly pinnately branched, branches subjulaceous, to $6 \mathrm{~mm}$ long. Pseudoparaphyllia triangular to truncate. Axillary hairs 3-4-celled, 65-90 x 89(11) $\mu \mathrm{m}$, apical cell ca. $50 \mu \mathrm{m}$ long. Stem leaves 2.3 x $0.9 \mathrm{~mm}$, ovate-lanceolate, gradually acuminate, widest at about $1 / 5$ of leaf length; slightly concave, slightly plicate; at base longly and rather broadly decurrent; costa reaching 0.4-0.6 of leaf length, 30$70 \mu \mathrm{m}$ wide at base; margin subentire to weakly serrulate nearly throughout. Median laminal cells $60-100 \times 6-8(4.5-6.5 / 1.0-1.5) \mu \mathrm{m}$; at base cells wider in 2-4 rows, in leaf corner cells usually not differentiated or sometimes indistinctly smaller or larger. Branch leaves similar in shape, but narrower; costa not ending in distinct spine. Autoicous (few collections); most plants have only perichaetia or lack gametangia; sporophytes were not seen in Altaian plants. [Reported as autoicous and polyoicous. Seta smooth. Operculum conic].

Brachythecium mildeanum has the size of $B$. salebrosum or is a little larger, and can be recognized by the following combination of characters: (1) leaves slightly plicate; (2) leaf margin subentire to weakly serrulate; (3) basal cells in most collections are enlarged and homogeneous across the entire base. However, in most specimens some leaves have laxer alar cells as well as some leaves with smaller alar cells. Many leaves of plants from river-sides of the steppe zone have smaller ("salebrosum-like") alar cells in most leaves, whereas in plants from stream-sides of mossy forests and subalpine communities many leaves have lax ("rivulare-like") alar cells.

In high mountains Brachythecium mildeanum is represented by plants with larger leaves, that are more abruptly acuminate, and more strongly plicate, and rather shortly decurrent (Fig. 18), whereas at the low elevations leaves are usually gradually acuminate, weakly plicate, and with longer decurrencies (Fig. 17). The former plants agrees with the description of $B$. udum Hag., Kongl. Norske Vidensk. Selsk. Skrift. 3: 4. 1908. (B. mildeanum var. udum Mönk. ex O. Mírt.,Kungl. Svenska Vetensk. Avhandl. Natursk. 14: 279. 1956 "nudum"). However I failed to segregate this taxon based on leaf characters due to numerous intermediate specimens. The sexuality (B. udum reported as dioicous, $B$. mildeanum as autoicous and polyoicous) provides little help, since this wetland species in Siberia often has only perichaetia in plants with leaf characters of typical $B$. mildeanum. Some authors considered $B$. udum to be closely related to B. turgidum, or interpreted it as a variety of the latter due to more strongly plicate leaves and more robust plants. However, the presence of relatively delicate leaves with thin-walled cells seem to disprove its close relationship with $B$. turgidum.

At lower elevations Brachythecium mildeanum can be confused with $B$. salebrosum and B. rotaeanum, both species of the same size. Wet-habitat phenotypes of $B$. salebrosum are weakly plicate, have more weakly serrulate leaf margins, and wider cells in the leaf corners so that the alar group sometimes almost disappears. Brachythecium mildeanum differs from such plants in its (1) shorter leaves, that are never secund, but rather longly and broadly decurrent; (2) costa not ending in sharp tooth on abaxial branch leaf. Brachythecium rotaeanum is similar to B. mildeanum in having straight leaves, that are sometimes weakly serrate, and in its autoicous or polyoicous inflorescence. However B. rotaeanum has more closely imbricate leaves, that are longly acuminate and strongly plicate, and the alar group is usually distinct.

At the upper elevations Brachythecium mildeanum can be confused with $B$. turgidum and $B$. erythrorrhizon ssp. asiaticum. The former differs from $B$. mildeanum in (1) very densely imbricate 


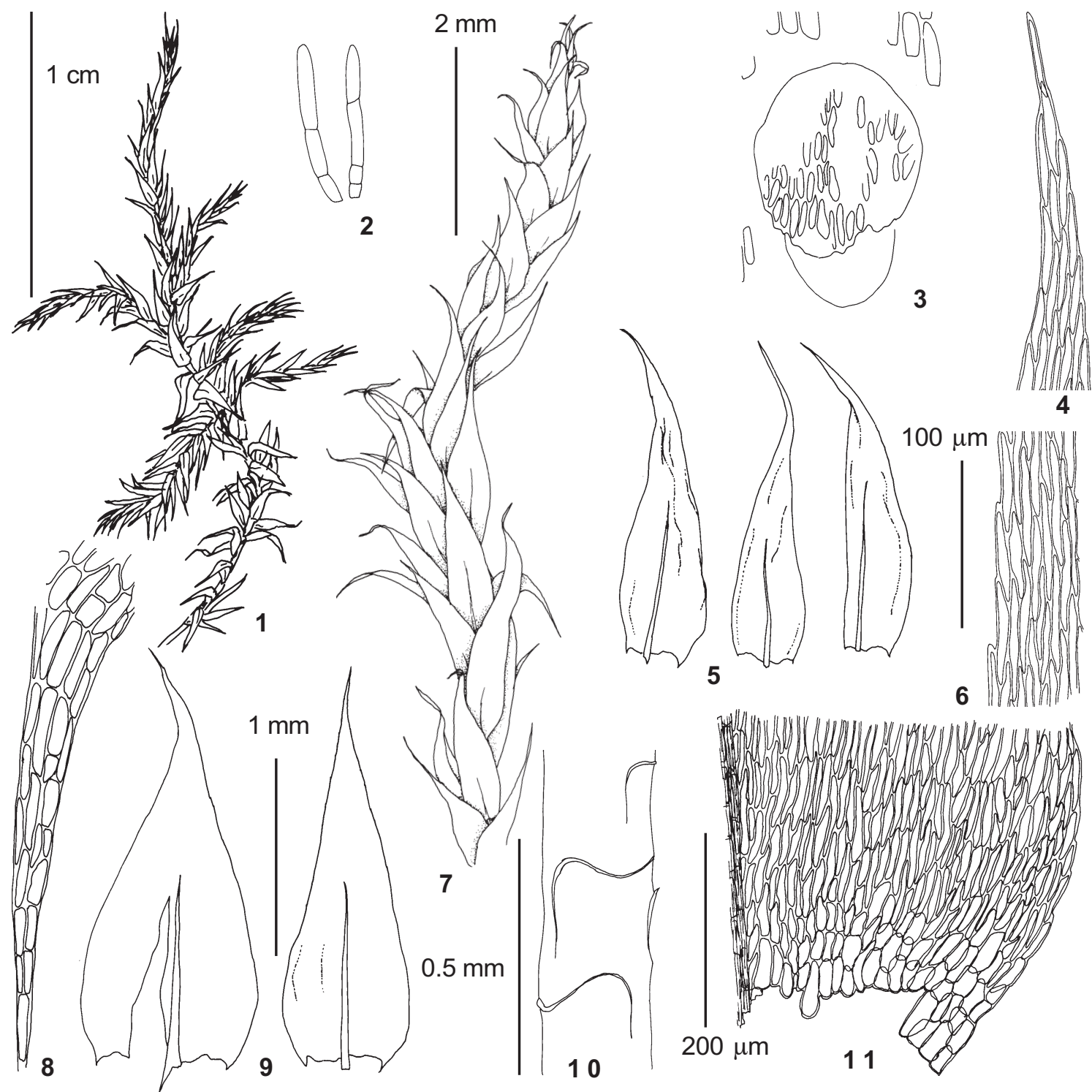

Fig. 17. Brachythecium mildeanum (Schimp.) Schimp. ex Milde (from Ignatov 0/445): 1 - habit; 2 - axillary hairs; 3 - branch initial with pseudoparaphyllia; 4 - upper laminal cells of stem leaf; 5 - branch leaves; 6 - median laminal cells of stem leaf; 7 - upper part of stem; 8 - leaf decurrency; 9 - stem leaves; 10 - stem leaf insertions; 11 - basal cells of stem leaf. Scale bars: $1 \mathrm{~cm}$ for $1 ; 2 \mathrm{~mm}$ for $7 ; 1 \mathrm{~mm}$ for 5,$9 ; 0.5 \mathrm{~mm}$ for $10 ; 200 \mu \mathrm{m}$ for 3, 11; $100 \mu \mathrm{m}$ for 2, 4, 6, 8, 11 .

leaves; (2) more strongly plicate leaves; (3) having small but distinct alar groups of small cells; (4) having thick-walled laminal cells (cell walls usually $2.5-3 \mu \mathrm{m}$ vs. ca. $1.5 \mu \mathrm{m}$ in $B$. mildeanum). Brachythecium erythrorrhizon differs from $B$. mildeanum in (1) strongly plicate and concave leaves; (2) distinct alar group of smaller cells; (3) \pm falcate leaves (never so in $B$. mildeanum); (4) usually rich green color (pale-green to golden in high mountain populations of $B$. mildeanum).

Distribution: This species is rather common in northern and mountain regions of Eurasia. In North America it has been reported in the recent literature only for Western Canada (Ireland \& al., 1987) and it has also not been reported from China and Japan. Hedenäs (pers. com.) found it in Australia, where it has probably been introduced. In European Russia and the lowlands of Western Siberia it is rather common in the boreal zone, becoming rarer towards the south. In Altai, B. mildeamum has scattered localities at all elevations, but most collections are from the alpine and subalpine zones. This species grows on wet soil (stream-sides, wet meadows), sometimes in hollows in Sphagnum bogs, and also over low boulders, but it has never been collected on steep rock outcrops (unlike B. turgidum). 


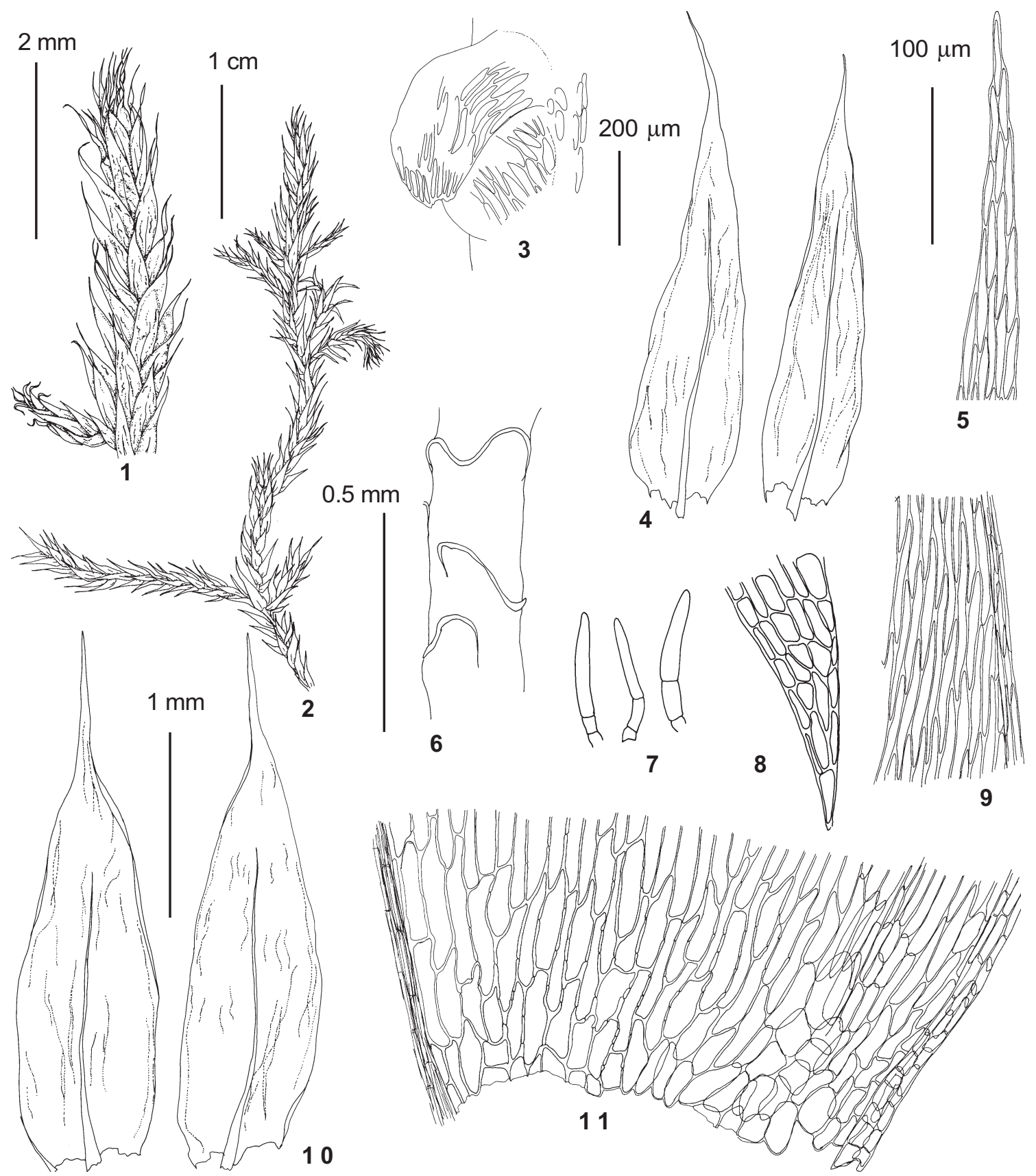

Fig. 18. Brachythecium mildeanum (Schimp.) Schimp. ex Milde, high-mountain phenotype (from Ignatov $0 /$ 492): 1 - upper part of stem; 2 - habit; 3 - branch initial with pseudoparaphyllia; 4 - branch leaves; 5 - upper laminal cells of stem leaf; 6 - stem leaf insertions; 7 - axillary hairs; 8 - leaf decurrency; 9 - median laminal cells of stem leaf; 10 - stem leaves; 11 - basal cells of stem leaf. Scale bars: $1 \mathrm{~cm}$ for $2 ; 2 \mathrm{~mm}$ for $1 ; 1 \mathrm{~mm}$ for 4,$10 ; 0.5 \mathrm{~mm}$ for $6 ; 200 \mu \mathrm{m}$ for $3 ; 100 \mu \mathrm{m}$ for $5,8,9,11$.

Specimens examined: Adylda Creek 1100 m (34/156); Ayulyuyuzyuk Creek $2300 \mathrm{~m}(0 / 379)$; Bashkaus River, up per course $2250 \mathrm{~m}(0 / 2037)$; Chulcha River, in middle course $1000 \mathrm{~m}(9 / 22) ;$ Kairu Creek, 16 km upstream $1400 \mathrm{~m} \mathrm{(14/}$ 7); Kayakkatuyarykskij Creek $1760 \mathrm{~m}(8 / 113 ; 8 / 114 ; 8 /$ 195), $1920 \mathrm{~m}(3 / 218), 1930 \mathrm{~m}(3 / 175 ; 3 / 271), 1940 \mathrm{~m}(3 /$ 263), 2350 m (7/91); Kobiguayuk Creek 2300 m (0/1661;
0/1662), $2500 \mathrm{~m}(0 / 192), 2700 \mathrm{~m}(0 / 1664), 2850 \mathrm{~m}(0 /$ 220); Korundushi (Schischkin 3.IX.1931 LE!); Krasivoye Lake $2530 \mathrm{~m}(36 / 200)$; Kukol $1750 \mathrm{~m}(0 / 1665), 1760 \mathrm{~m}(0 / 445)$, $1800 \mathrm{~m}(0 / 1663), 1850 \mathrm{~m}(0 / 492) ;$ Mukhor-Tarkhaty 2000 m (Polyanskaya 18.VIII.1937 LE!); Seminskij Pass $1660 \mathrm{~m}$ (Bardunov 27.VI.1966); Tabozhok Creek, uppermost right branch $2600 \mathrm{~m}(36 / 285), 2700 \mathrm{~m}(36 / 284) ;$ Tabozhok Peak 
$2700 \mathrm{~m}$ (31/298); Tokpak Creek, in middle course $1950 \mathrm{~m}$ (36/280); Ulagan 1220 m (36/416); Uzuntytygem Creek, upper course $2400 \mathrm{~m}(36 / 413 ; 36 / 414)$.

Brachythecium complanatum Broth., Rev. Bryol. n. ser. 2: 11. 1929. Fig. 19.

Plants robust, light-green to whitish. Stem \pm regularly branched, branches subjulaceous to somewhat complanate, to $13 \mathrm{~mm}$ long. Pseudoparaphyllia longtriangular to lanceolate. Axillary hairs 2-3-celled, 35$55 \times 7-10 \mu \mathrm{m}$, apical cell to $25 \mu \mathrm{m}$ long. Stem leaves $2.2-$ $3.0 \times 1.0-1.3 \mathrm{~mm}$, ovate-lanceolate, gradually to abruptly acuminate, widest at ca. 1/7 of leaf length; concave, distinctly crumplingly plicate (i. e. plicae differently oriented); at base shortly decurrent; costa reaching 0.50-0.65 of leaf length, 30-70(90) $\mu \mathrm{m}$ wide at base; margin serrate above, serrulate to subentire towards the base. Median laminal cells 55-90(110) x 6-9 (3-6/1.52.5) $\mu \mathrm{m}$; across leaf base cells wider in several rows, in leaf corners not clearly delimited or forming indistinct square group of subquadrate cells. Branch leaves narrower; more strongly serrate, costa ending in very indistinct spine. Dioicous. Perichaetia and perigonia on stem. Perichaetial leaves abruptly very longly acuminate, costa short. Paraphyses numerous, exserted from perichaetia. Seta to $1.3 \mathrm{~mm}$, strongly mammillose. Capsule $1.8 \mathrm{~mm}$ long, inclined, light-brown. Operculum not seen. Calyptra with sparse hairs. Spores 20-22 $\mu \mathrm{m}$.

Brachythecium complanatum is a little known species, described by sterile specimen from the Amurskaya Province of the Russian Far East ("Amur, distr. Zeisko-Bureinsk, Mikhailofskoje, 25.VI.1910 Korotki”, holotype H-BR!, isotype LE!). At first Altaian material of this species was identified as $B$. wichurae (Broth.) Par. (Ignatov, 1992, 1994; Ignatov \& Afonina, 1992), a species superficially very similar to B. complanatum. Later Ignatov \& Koponen (1996) synonymized both $B$. wichurae and $B$. complanatum with $B$. garovaglioides C. Müll. However, in the cousre of this study I found one Altaian specimen of this species having sporophytes with strongly mammillose setas and hairy calyptras (B. garovaglioides has smooth seta and naked calyptra). Although other Altaian collections are sterile, the material is homogeneous and therefore all these collections are referred to $B$. complanatum. Brachythecium garovaglioides is excluded from the flora of Altai and South Siberia.

When sterile $B$. complanatum and $B$. garovaglioides $C$. Müll. can be distinguished as follows: (1) in B. garovaglioides the leaves are widest at ca. 1/4-1/5 of leaf length, 土abruptly tapered to the acumen, and strongly rounded towards the insertion, whereas in $B$. complanatum leaves are widest at ca. $1 / 7$ of leaf length, \pm gradually tapered to the acumen, and slightly rounded towards the insertion; (2) the cells of the leaf base are on the average $15 \mu \mathrm{m}$ wide in $B$. garovaglioides and $10 \mu \mathrm{m}$ in B. complanatum. Slender plants of $B$. complanatum from shady habitat have \pm complanate branches (and the type also belongs to this phenotype), while most specimens have subjulaceous or slightly complanate branches.

Brachythecium complanatum is probably closely related to $B$. coreanum Card., a species known from Korea and Japan and reported also from China. Both species have robust plants, concave, strongly plicate leaves with serrate margin, mammillose setas and hairy calyptras. The latter is a very rare character in the genus Brachythecium and its presence in both $B$. complanatum and $B$. coreanum can be interpreted as an evidence of their close relationshi p. However, B. coreanum has more rigid and straight (not flexuose above), narrower leaves with longitudinal plicae, and more densely imbricate foliage. The habit of $B$. complanatum and B. coreanum is strikingly different, so there is not necessary to lump them.

I did not study the type of Brachythecium coreanum and the present concept of this species is based on its descriptions by Takaki (1955b), with drawnings from the type collection, and Noguchi (1991), and 5 collections from Japan ( $\mathrm{H}$ and LE), including exsiccate Musci Japonici \#205 (cited by Takaki, 1955b), and type of $B$. piliferum Broth., which has been synonymised with $B$. coreanum by Takaki (1955b).

Brachythecium complanatum is superficially similar to B. salebrosum in its robust plants, serrate and somewhat falcate leaves. These species can, however, be distinguished by many characters:

\section{B. complanatum B. salebrosum}

Plants $\quad \pm$ soft, pale to $\quad \pm$ rigid, green to whitish-green yellow-green

Stem often flexuose not flexuose

Branching irregular (many \pm regular (branches pattern branches much shorter) of \pm same length)

Leaves ovate, ovate-lanceolate, abruptly acumimate gradually acuminate

Plicateness crumpling longitudinal

Alar cells weakly differentiated well differentiated 


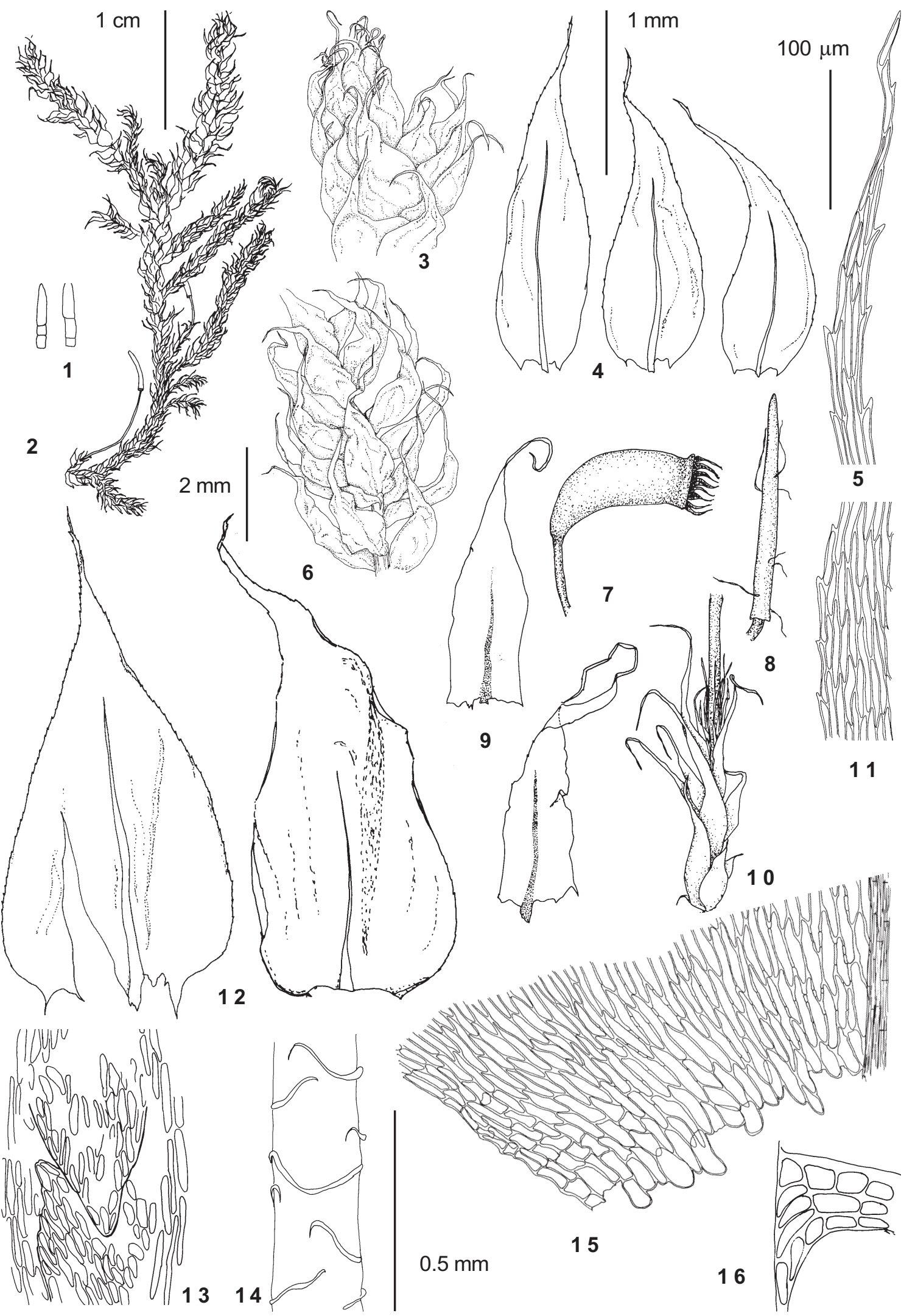


Distribution: Besides from Altai, I have seen specimens of B. complanatum from the Russian Far East (Khabarovsk Territory, Amurskaya Province). In Altai it is a relatively rare species, occurring at lower elevations, mostly in areas with a mild climate (surroundings of Teletzkoye Lake, middle range of Katun River). It grows on the forest floor, on rotten logs, soil and rocks, in diffusely shaded habitats.

Specimens examined: Chemal $400 \mathrm{~m}(29 / 53)$; Che mal Creek, $3 \mathrm{~km}$ upstream $450 \mathrm{~m}(34 / 13)$; Chiri Creek, $0.5 \mathrm{~km}$ upstream $450 \mathrm{~m}(17 / 79)$; Elekmonar Creek, $5 \mathrm{~km}$ upstream $700 \mathrm{~m}$ (26/14); Kumzir $450 \mathrm{~m}$ (20/20); Srednij Shaltan Creek $640 \mathrm{~m}(0 / 1678)$; Ust-Sema $330 \mathrm{~m}$ (24/26), $400 \mathrm{~m}(24 / 45)$; Yailyu $450 \mathrm{~m}(1 / 20 ; 1 / 72)$; Yurga $440 \mathrm{~m}(21 / 14)$.

Brachythecium rutabulum (Hedw.) B. S. G., Bryol. Eur. 6: 15. pl. 543 (fasc. 52-54 Monogr. 11. pl. 9). 1853.

Fig. 20

Hypnum rutabulum Hedw., Sp. Musc. Frond. 276. 1801.

Plants green, glossy. Stem rather regularly pinnate branched, branches subjulaceous, to $10 \mathrm{~mm}$ long. Pseudoparaphyllia triangular. Axillary hairs 2-3-celled, to $85 \times 9-12 \mu \mathrm{m}$, apical cell to $60 \mu \mathrm{m}$ long. Stem leaves $2.3 \times 1.4 \mathrm{~mm}$, broadly ovate to ovate, gradually acuminate, suddenly narrowed at base, widest at ca. $1 / 7$ of leaf length; slightly concave and moderately plicate; at base longly decurrent; costa reaching 0.4-0.6 of leaf length, ca. $70 \mu \mathrm{m}$ wide at base; margin serrate above, serrulate below. Median laminal cells 80-125 x 9-11 (8-9/2.0-2.5) $\mu \mathrm{m}$; towards base wide (to $15 \mu \mathrm{m}$ ) in 3-4 rows, in leaf corner enlarged cells forming submarginal group. Branch leaves narrower; costa ending in indistinct spine. Autoicous, perichaetia and perigonia on stem. Perichaetial leaves abruptly longly acuminate, with weak, short costa. Seta to $20 \mathrm{~mm}$, strongly mammillose. Capsule $2.0 \mathrm{~mm}$ long, horizontal, curved. Operculum conic. Spores 20-22 $\mu \mathrm{m}$.

Characters separating this species from $B$. rivulare are discussed under the latter.

Distribution: Widely distributed species, occurring in the southern part of boreal and in the temperate zones, and also in high mountains at lower latitudes. In Siberia B. rutabulum is restricted to the southern regions. In Altai it was collected only a few times at the lowermost elevations, on rocks in wet narrow valleys in the surroundings of Teletzkoye Lake.

Specimens examined: Baigazan $450 \mathrm{~m}$ (0/1645); Chiri Creek, $0.5 \mathrm{~km}$ upstream $450 \mathrm{~m}$ (17/75); Kairu Creek, 8 km upstream 1000 m (15/153); Kyga (Lebedeva \& al. 18.IX.1977); Yailyu $450 \mathrm{~m}(0 / 1672)$.
Brachythecium rivulare B.S.G., Bryol. Eur. fasc. 52-54. Monogr. 13. pl. 12 (6: 17. pl. 546). 1853.

Fig. 21

Plants green, whitish-green to yellow-brownish. Stem regularly or irregularly branched, branches subjulaceous, to $20 \mathrm{~mm}$ long, sympodial branches common (especially in temporarily flooded habitats). Pseudoparaphyllia triangular. Axillary hairs 2-3celled, to $70-80 \times 7 \mu \mathrm{m}$, apical cell 55-65 $\mu \mathrm{m}$ long. Stem leaves to $2.3 \times 1.5 \mathrm{~mm}$, ovate, gradually shortly acuminate, widest at $1 / 5-1 / 7$ of the leaf length; moderately concave, weakly to moderately plicate; at base very longly and broadly decurrent; costa reaching 0.6-0.7 of leaf length, 65-80(130) $\mu \mathrm{m}$ wide at base; margin serrate to subentire. Median laminal cells (50)70-110(150) x 8-11 (5.5-8/1.5-3.0) $\mu \mathrm{m}$; in leaf corner cells enlarged and inflated, forming distinctly delimited group of subquadrate cells (15$20 \mu \mathrm{m}$ wide), reaching $1 / 2$ of distance to costa; basal marginal cells long-rectangular in 1-2 rows. Branch leaves ovate-lanceolate to narrow triangular; costa ending in short spine. Dioicous, rarely autoicous. Gametagia and sporophytes were not found in Altaian specimens [Seta mammillose. Capsule inclined. Peristome complete, cilia nodose. Operculum high-conic].

Brachythecium rivulare can be confused with Bryhnia novae-angliae, B. latifolium (their differences are discussed under two latter species) and $B$. rutabulum. Typically, B. rivulare differs from $B$. rutabulum in: (1) acute (not acuminate) leaves; (2) dioicous (not autoicous) sexuality; (3) abruptly (not gradually) delimited alar cells; (4) numerous sympodial branches, which are typically orthotropous, "subdendroid", so the tufts of $B$. rivulare look lax (in $B$. rutabulum the branching is almost pinnate and the tufts look denser); (5) B. rivulare is frequently characteristically whitish-green in young parts, whereas $B$. rutabulum is mostly having a rich-green to yellow-green color.

Alar areolation is probably the most useful character for the segregation of these species. In $B$. rivulare enlarged cells are differentiated abruptly and occupy almost the whole leaf corner and decurrency; cells of 1-2 marginal cell rows are rectangular, but usually also thin-walled and enlarged compared with the cells of the leaf margin above. Contrary to this, in $B$. rutabulum the basal marginal cells are undifferentiated in

$\leftarrow$ Fig. 19. Brachythecium complanatum Broth. (from Ignatov 24/45): 1 - axillary hairs; 2 - habit; 3 - upper part of stem; 4 - branch leaves; 5 - upper laminal cells of stem leaf; 6 - middle part of stem; 7 - capsule; 8 - calyptra; 9 - perichaetial leaves; 10 - perichaetium; 11 - median laminal cells of stem leaf; 12 - stem leaves; 13 - branch initial with pseudoparaphyllia; 14 - stem leaf insertions; 15 - basal cells of stem leaf; 16 - leaf decurrency. Scale bars: $1 \mathrm{~cm}$ for $2 ; 2 \mathrm{~mm}$ for $3,6-8,10 ; 1 \mathrm{~mm}$ for $4,9,12 ; 0.5 \mathrm{~mm}$ for $14 ; 100 \mu \mathrm{m}$ for $1,5,11,13,15-16$. 


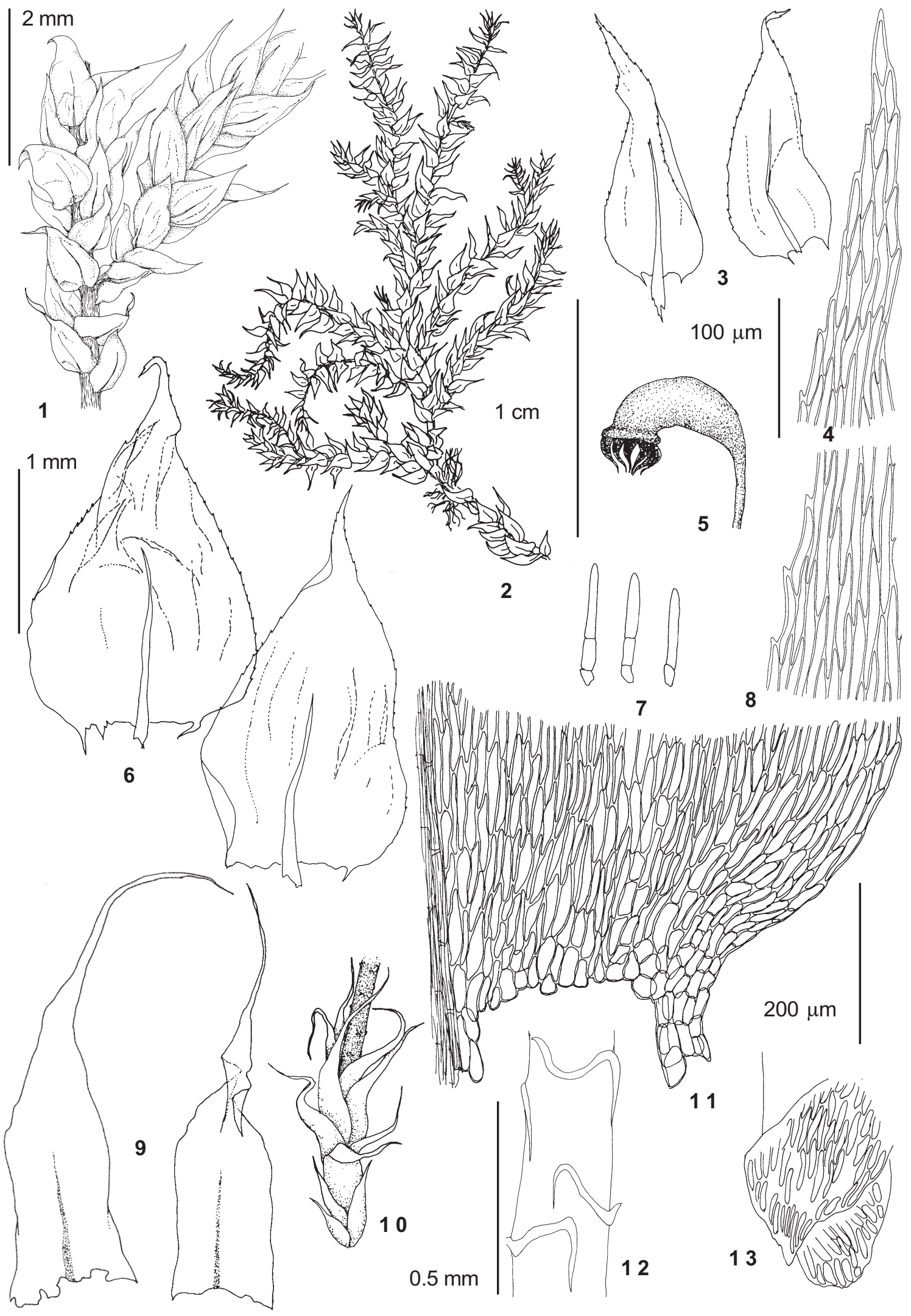




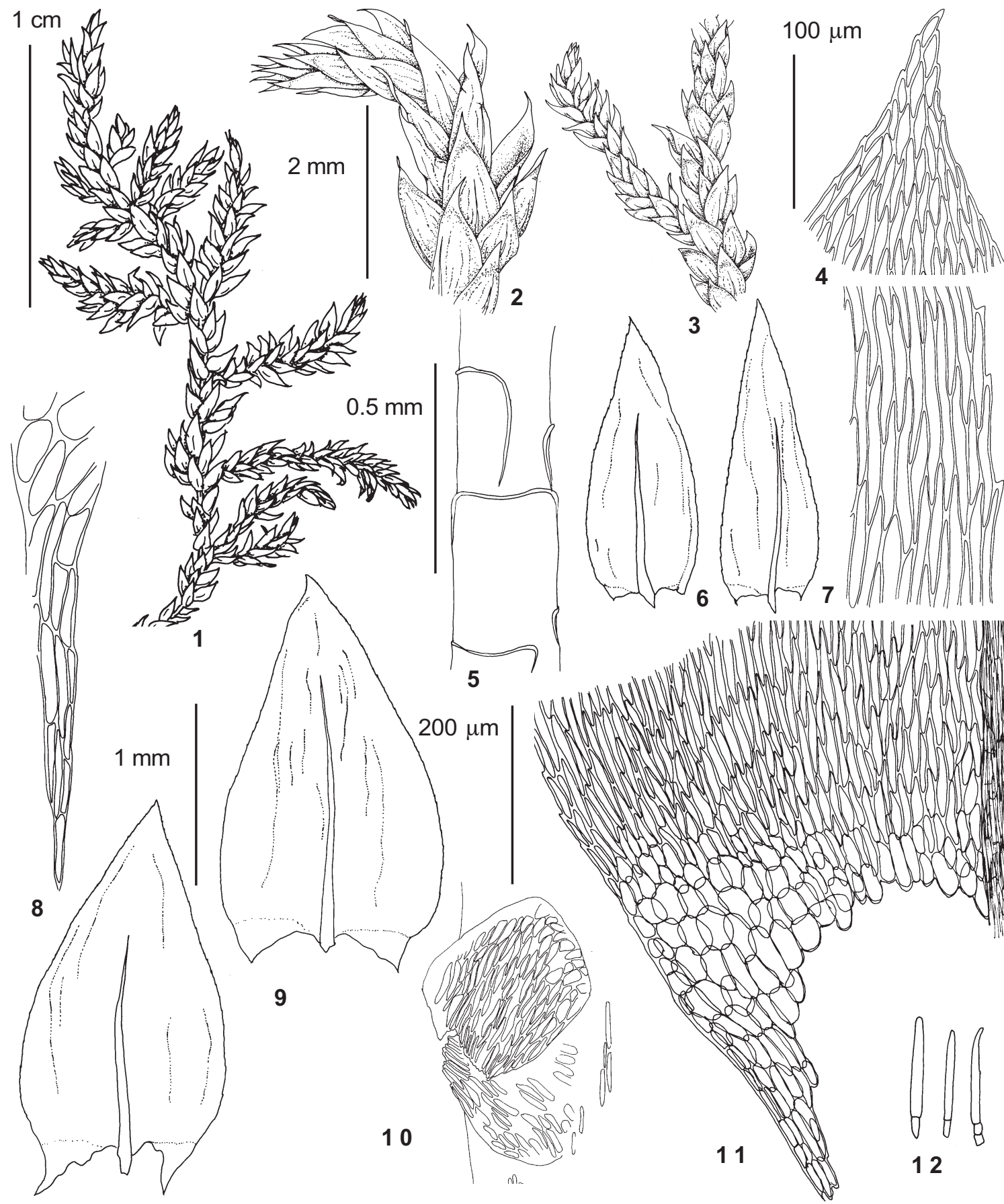

Fig. 21. Brachythecium rivulare B. S. G. (from Ignatov 18/58): 1 - habit; 2 - upper part of stem; 3 - part of stem with proximal part of branch; 4 - upper laminal cells of stem leaf; 5 - stem leaf insertions; 6 - branch leaves; 7 median laminal cells of stem leaf; 8 - leaf decurrency; 9 - stem leaves; 10 - branch initial with pseudoparaphyllia; 11 - basal part of stem leaf; 12 - axillary hairs. Scale bars: $1 \mathrm{~cm}$ for $1 ; 2 \mathrm{~mm}$ for 2-3; $1 \mathrm{~mm}$ for 6,$9 ; 0.5 \mathrm{~mm}$ for 5 ; $200 \mu \mathrm{m}$ for $10-11 ; 100 \mu \mathrm{m}$ for $4,7-8,12$.

$\leftarrow$ Fig. 20. Brachythecium rutabulum (Hedw.) B. S. G. (1-4, 6-8, 11-13 - from Ignatov 15/153; 5, 9-10 - from Ignatov 17/75): 1 - upper part of stem; 2 - habit; 3 - branch leaves; 4 - upper laminal cells of stem leaf; 5 capsule; 6 - stem leaves; 7 - axillary hairs; 8 - median laminal cells of stem leaf; 9 - perichaetial leaves; 10 perichaetium; 11 - basal cells of stem leaf; 12 - stem leaf insertions; 13 - branch initial with pseudoparaphyllia. Scale bars: $1 \mathrm{~cm}$ for $2 ; 2 \mathrm{~mm}$ for $1,5,10 ; 1 \mathrm{~mm}$ for $3,6,9 ; 0.5 \mathrm{~mm}$ for $12 ; 200 \mu \mathrm{m}$ for $11 ; 100 \mu \mathrm{m}$ for 4, 7-8, 11, 13 . 


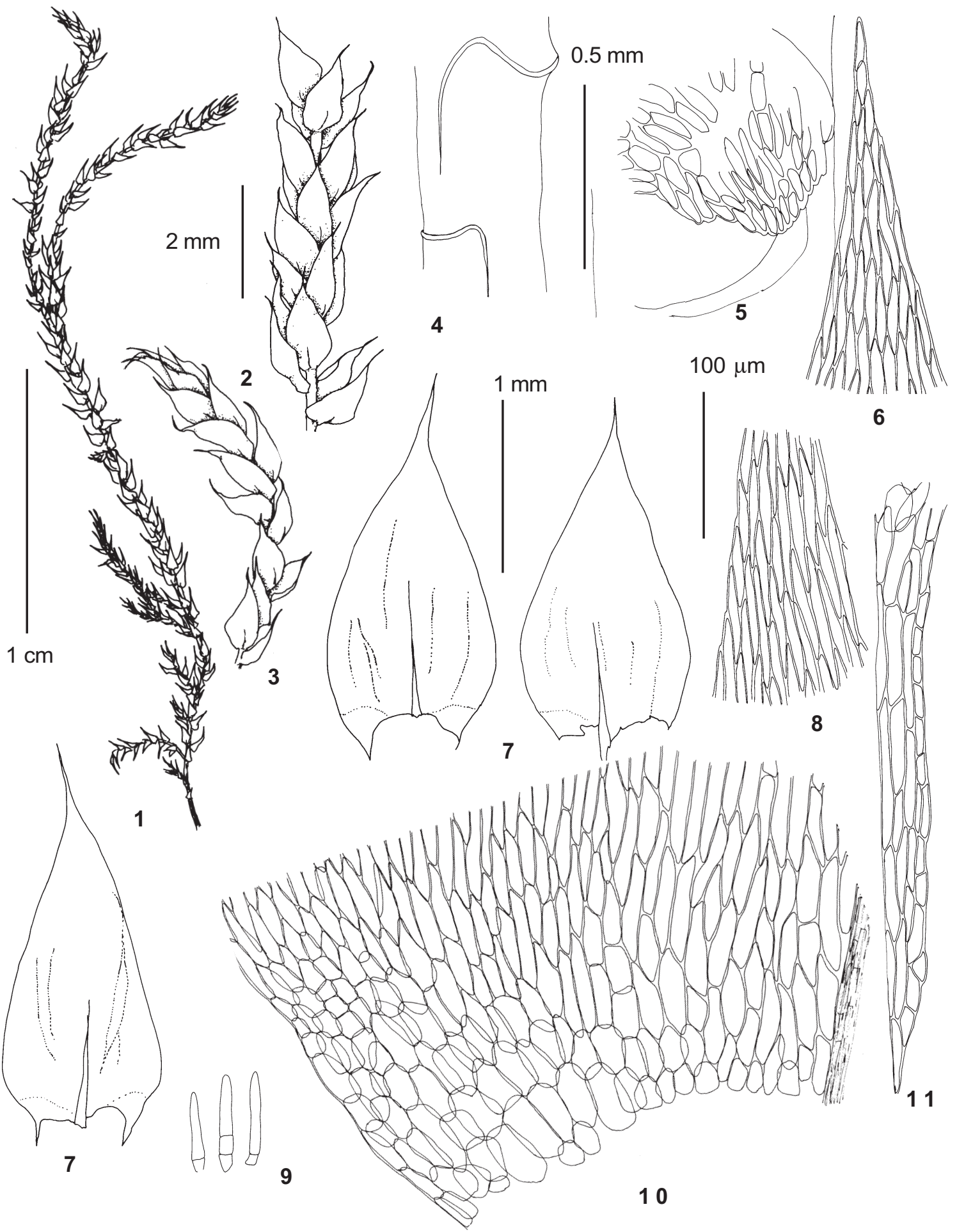

Fig. 22. Brachythecium latifolium Kindb. (from Ignatov 0/400): 1 - habit; 2 - middle part of stem; 3 - upper part of stem; 4 - stem leaf insertions; 5 - branch initial with pseudoparaphyllia; 6 - upper laminal cells of stem leaf; 7 - stem leaves; 8 - median laminal cells of stem leaf; 9 - axillary hairs; 10 - basal cells of stem leaf; 11 - leaf decurrency. Scale bars: $1 \mathrm{~cm}$ for $1 ; 2 \mathrm{~mm}$ for 2-3; $1 \mathrm{~mm}$ for 7; $0.5 \mathrm{~mm}$ for $4 ; 100 \mu \mathrm{m}$ for 5-6, 8-11. 
3-5 rows, and the differentiated alar group is clearly submarginal. Also, in B. rutabulum margin is usually recurved and more strongly narrowed at leaf base than in $B$. rivulare.

However none of characters mentioned above is completely reliable. Wigh (1975) demonstrated by cultivation experiments, that under wet condition $B$. rutabulum can develop alar groups indistinguishable from those of $B$. rivulare. Autoicous sexuality can sometimes be found in $B$. rivulare too (Robinson, 1962, Wigh, 1975). Though sympodial branches are numerous in many collections of $B$. rivulare, some plants are only pinnately branched. Leaf shape is also difficult to judge in some cases, because in collections with numerous sympodial branches it is difficult to find "real" stem leaves.

Two more differences between $B$. rivulare and $B$. rutabulum are difficult to use for their identification, but they seems important for support of their status as two independent species. Wigh (1975) revised all literature data on chromosome numbers of $B$. rivulare and $B$. rutabulum and also studied many Scandinavian populations, and found that the former species has always $n=6$ and the latter always $n=12$. According to our observations on peristome ornamentation (Ignatov \& al., 1998a), B. rivulare has the inner upper surface of the exostome teeth with uniform dense and high papillae, whereas in $B$. rutabulum the papillae are sparse and low.

Distribution: Brachythecium rivulare is a widespread species, very common in most parts of boreal and north-temperate zones of the Holarctic, and also in all continents of South Hemisphere. In Altai it is abundant in czernevaya taiga of lower elevations, more rare in the boreal forest belt, but never found in subalpine and alpine zones. It grows in different kinds of wet habitats, including creek and stream sides, dripping cliffs, boggy meadows and forests.

Specimens examined: Adylda Creek $1100 \mathrm{~m}$ (34/157); Bayas Creek, in middle course $750 \mathrm{~m}(16 / 8), 1000 \mathrm{~m}(16 /$ 21); Bele $500 \mathrm{~m}(0 / 40)$; Bolshoye Istyube Creek $470 \mathrm{~m}$ (Zolotukhin 5.VII.1988; 0/1671; 18/58; 18/6); GornoAltaisk (SE edge) $600 \mathrm{~m}(23 / 25)$; Kairu Creek, $16 \mathrm{~km}$ upstream $1400 \mathrm{~m}(14 / 10)$; Kamga creek. $4 \mathrm{~km}$ upstream $460 \mathrm{~m}$ (0/3007); Kandash Creek $1700 \mathrm{~m}$ (Zolotukhin \& al. 17.VIII.1980); Karagai $440 \mathrm{~m}(0 / 1674 ; 0 / 258)$; Karakaya (Volkova 17.VIII.1937 LE!); Kobiguayuk Creek 2100 m (0/1728; 0/415), 2150 m (0/121); Kobukhtushka 440 m (0/1673; 0/1726); Maima 280 m (35/34); Ok-Porok Creek, at mouth $440 \mathrm{~m}(0 / 489)$; Srednij Shaltan Creek $620 \mathrm{~m}$ (0/1727); Uedinennoye Lake $880 \mathrm{~m}$ (0/2035); Yailyu 470 m (Zolotukhin 29.IX.1990).
Brachythecium latifolium Kindb., Forh. Vidensk.-Selsk. Christiania 1888(6): 8. $1888 . \quad$ Fig. 22

Plants yellow-green to yellow-brownish. Stem irregularly branched, branches subjulaceous, to $6 \mathrm{~mm}$ long. Pseudoparaphyllia triangular. Axillary hairs 2-3-celled, to $60 \times 9 \mu \mathrm{m}$, apical cell to $50 \mu \mathrm{m}$ long. Stem leaves to $2.1 \times 1.0 \mathrm{~mm}$, ovate, gradually tapered to short acumen, widest at $1 / 5-1 / 7$ of the leaf length; moderately concave, not or slightly plicate; at base longly decurrent; costa reaching 0.30.5 of leaf length, $30-45 \mu \mathrm{m}$ wide at base; margin subentire. Laminal cells 70-90 x 7-9 (5.5-7/1.5-2.0) $\mu \mathrm{m}$; at base wider in several rows, in leaf corner cells enlarged and inflated, forming \pm well-delimited group of subquadrate cells (to 15-18 $\mu$ m wide), reaching ca. 1/2 of distance to costa. Branch leaves ovate-lanceolate to narrow triangular; costa not ending in spine. Dioicous. Gametagia and sporophytes were not found in Altaian specimens [Seta mammillose. Capsule inclined. Peristome complete].

Brachytecium latifolium has alar cells that are \pm abruptly differentiated, as in $B$. rivulare. However B. latifolium differs from this species by its smaller plants, entire leaves and shortly, but abruptly acuminate leaves. Superficially $B$. latifolium is similar to B. glaciale, which also grows in similar habitats. However the latter species has small alar cells.

Distribution: This species has a scattered arcto-alpine distribution. I have seen specimens from Scandinavia and mountains of Canada (British Columbia); according to the literature it occurs also in mountains of Central Europe, Iceland, the Russian Arctic, the Ural Mountains, and in mountains of Northern Siberia. In Altai it was found only once, in the alpine zone, in boggy place near springs on a steep slope.

Specimen examined: Kobiguayuk Creek $2550 \mathrm{~m}$ (0/400).

Brachythecium ornellanum (Mol.) Vent. et Bott., Atti Soc. Critt. Ital. 3(3):161. 1884. - Hypnum ornellanum Mol., Ber. Naturhist. Vereins Augsburg 18: 185. 1865. - Scleropodium ornellanum (Mol.) Lor.,Bryol.Notizb.69.1865.- Cirriphyllum ornellanum (Mol.) Loeske, Stud. Morph. Syst. Laubm. 180. 1910. Type: "95. In terra subhumida petrosa inter parietes melaphyricas montis Padon in Livinallongo 75-8000'N. Unio itin. crypt. Molendo X.1863." (isotypes S!, LE!) Fig. 23

Hypnum apiculigerum Lindb. et H. Arnell, Kongl. Svenska Vetensk. Acad. Handl. 23(10): 132. 1890.- Cirriphyllum apiculigerum (Lindb.et H. Arnell) Broth., Nat. Pflanzenfam. 1(3): 1154. 1909. 


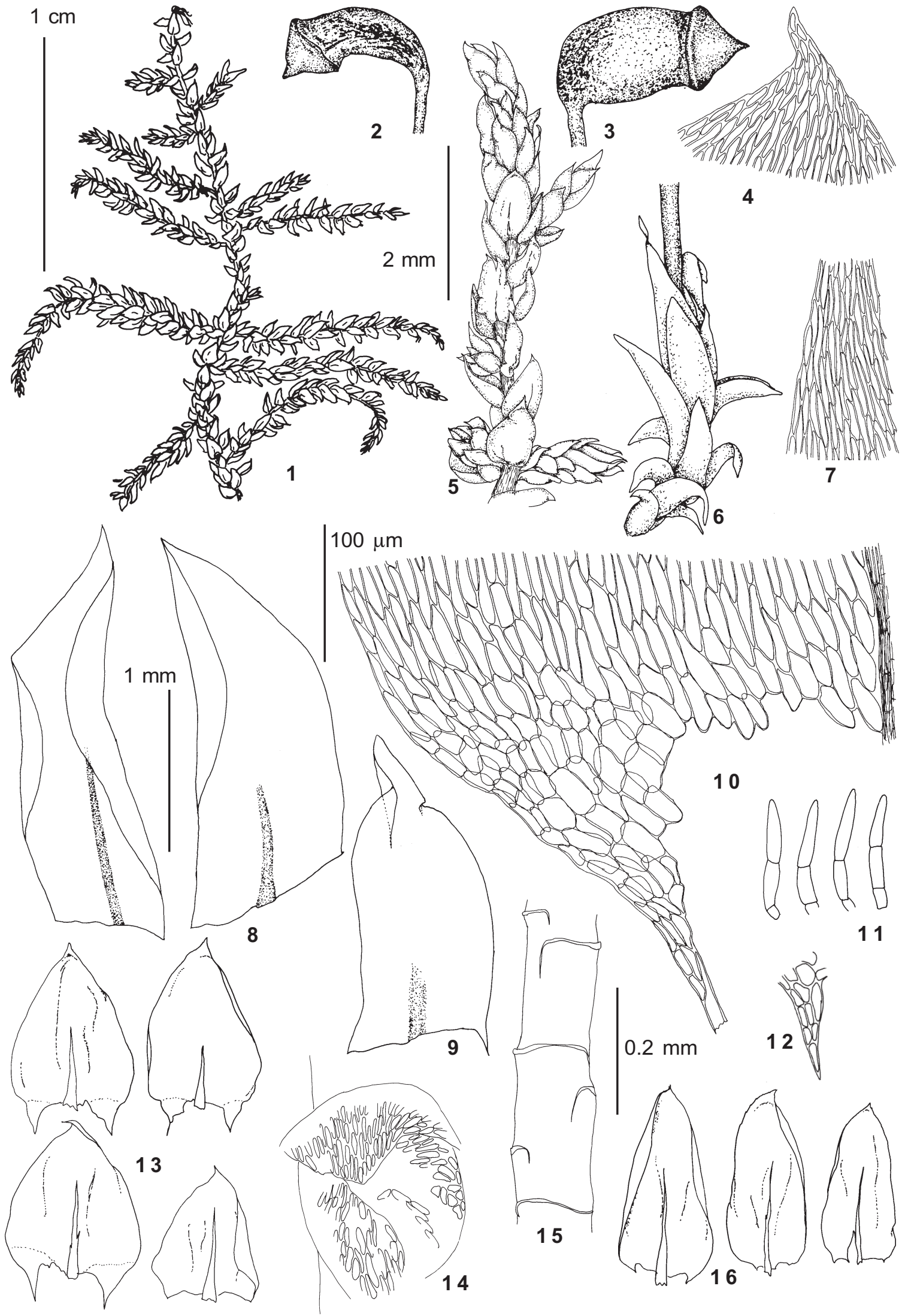


Table 2. A comparison of taxa, considered as related to Brachythecium ornellanum (Mol.) Vent. et Bott.

\begin{tabular}{|c|c|c|c|c|}
\hline & \multirow{2}{*}{$\begin{array}{c}\text { Cirriphyllum } \\
\text { piliferum }\end{array}$} & \multicolumn{2}{|c|}{ Brachythecium } & \multirow{2}{*}{$\begin{array}{c}\text { Scleropodium } \\
\text { touretii }\end{array}$} \\
\hline & & latifolium & ornellanum & \\
\hline Plant & soft & soft & soft & \pm rigid \\
\hline Branching & \pm regularly pinnate & irregular & \pm regularly pinnate & irregular \\
\hline Foliage & loose & loose & loose & dense \\
\hline Leaves & piliferous & acuminate & acute & acute \\
\hline $\begin{array}{l}\text { Width of median } \\
\text { laminal cell, } \mu \mathrm{m}\end{array}$ & $6-8$ & $7-9$ & $5-8$ & $4-6$ \\
\hline Basal cells & lax in & extensive & ea & lax in small group \\
\hline Operculum & rostrate & conic & conic & high-conic \\
\hline
\end{tabular}

Plants robust, green to whitish-green, forming loose mats. Stem prostrate, regularly remotely branched, branches often curved, subjulaceous, to $10 \mathrm{~mm}$ long. Pseudoparaphyllia triangular. Axillary hairs 3-celled, to $90 \times 9 \mu \mathrm{m}$, apical cell to $40 \mu \mathrm{m}$ long. Stem leaves erect-appressed, (0.7)1.0-1.3 x 0.6$1.0 \mathrm{~mm}$, broadly-ovate to ovate-triangular, broadly acute or apiculate, most wide at $1 / 5-1 / 7$ of leaf length; strongly concave, indistinctly plicate; at base longly and broadly decurrent; costa reaching 0.2 0.6 of leaf length, ca. $40 \mu \mathrm{m}$ wide at base, usually becoming much thinner shortly above leaf base; margin subentire to serrulate in upper half (especially in smaller leaves of stoloniferous shoots). Laminal cells $25-75$ x 5-8 (3-6/2.0-2.5) $\mu \mathrm{m}$; towards base cells wider and shorter in several rows; in leaf corner subquadrate cells (to $15-20 \mu \mathrm{m}$ ), forming extensive alar group \pm well delimited and reaching $1 /$ $2-2 / 3$ of distance to costa. Branch leaves ovate to lanceolate, abruptly shortly acute to apiculate; margin subentire, costa not ending in spine. Autoicous. Perigonia and perichaetia on stem. Inner perichaetial leaves to $2.8 \mathrm{~mm}$, acute, with short costa; outer ones obtuse, reflexed. Seta mammillose. Operculum conic. [Sporophytes and perichaetia described from plants from Kazakh Altai, Kirgyzia, and France].

This species can be recognized by its (1) laxly julaceous foliage; (2) broadly ovate, shortly acute to apiculate leaves; (3) broad leaf decurrencies.

The position of Brachythecium ornellanum is controversial - many authors put it in Scleropodium due to its julaceous foliage (Limpricht,
1895; Abramova \& al., 1961, Nyholm, 1965, etc). Another widespread point of view is to place B. ornellanum in Cirriphyllum near C. piliferum (Brotherus, 1925, etc.). Some authors even supposed that the former taxon can be a nonpiliferous form of $C$. piliferum (Monkenmayer, 1927; Geissler, 1984; Düll, 1994). I agree that the similarity between $B$. ornellanum and Cirriphyllum piliferum is more significant, than between the former and Scleropodium tourettii (Brid.) L. Koch, the type of Scleropodium (Table 1). However, the placement of B. ornellanum in Cirriphyllum makes impossible the explaination of difference between Brachythecium and Cirriphyllum at all.At the sametime, none of the characters of $B$. ornellanum disagree with Brachythecium, and especially with the species around $B$. latifolium and $B$. rivulare. Therefore I propose to reestablish a forgotten idea of Venturi and Bottini, and to place the taxon in question into Brachythecium.

Distribution: This species is known in Europe from a few localities in mountains of Central Europe (Italy, France, reported from Jugoslavia), in Kola Peninsula, north-eastern European Russia, Arctic and Northern Urals (south to $61^{\circ} \mathrm{N}$ ), and Caucasus. In Asia B. ornellanum is more widespread: it is known in the Eastern Siberian Arctic, Chukotka, Eastern Siberian lowland (Yenisej at ca. $62^{\circ}$, MW!), mountains of the South Siberia and of the Middle Asia (Kazakh Altai and Tian-Shan - LE!). In Altai $B$. ornellanum occurs in the subalpine and forest zones in tall-herb communities and also in herbaceous Betula

$\leftarrow$ Fig. 23. Brachythecium ornellanum (Mol.) Vent. et Bott. (1, 4-5, 7, 10-16 - from Ignatov 13/114; 2, 6, 8-9 - from Kazakh Altai, Polyakov 10.VI.1930 LE; 3 - from France, Savoie, 2020-2050 m alt., Catelli 5.X.1959, LE): 1 - habit; 23 - capsules; 4 - upper laminal cells of stem leaf; 5 - upper part of stem; 6 - perichaetium; 7 - median laminal cells of stem leaf; 8 - inner perichaetial leaves; 9 - outer perichaetial leaf; 10 - basal cells of stem leaf; 11 - axillary hairs; 12 - leaf decurrency; 13 - stem leaves; 14 - branch initial with pseudoparaphyllia; 15 - stem leaf insertions; 16 branch leaves. Scale bars: $1 \mathrm{~cm}$ for $1 ; 2 \mathrm{~mm}$ for 2-3, 5-6; $1 \mathrm{~mm}$ for 8-9, 13, 16; $0.2 \mathrm{~mm}$ for 14-15; $100 \mu \mathrm{m}$ for 4, 7, $10-12$. 


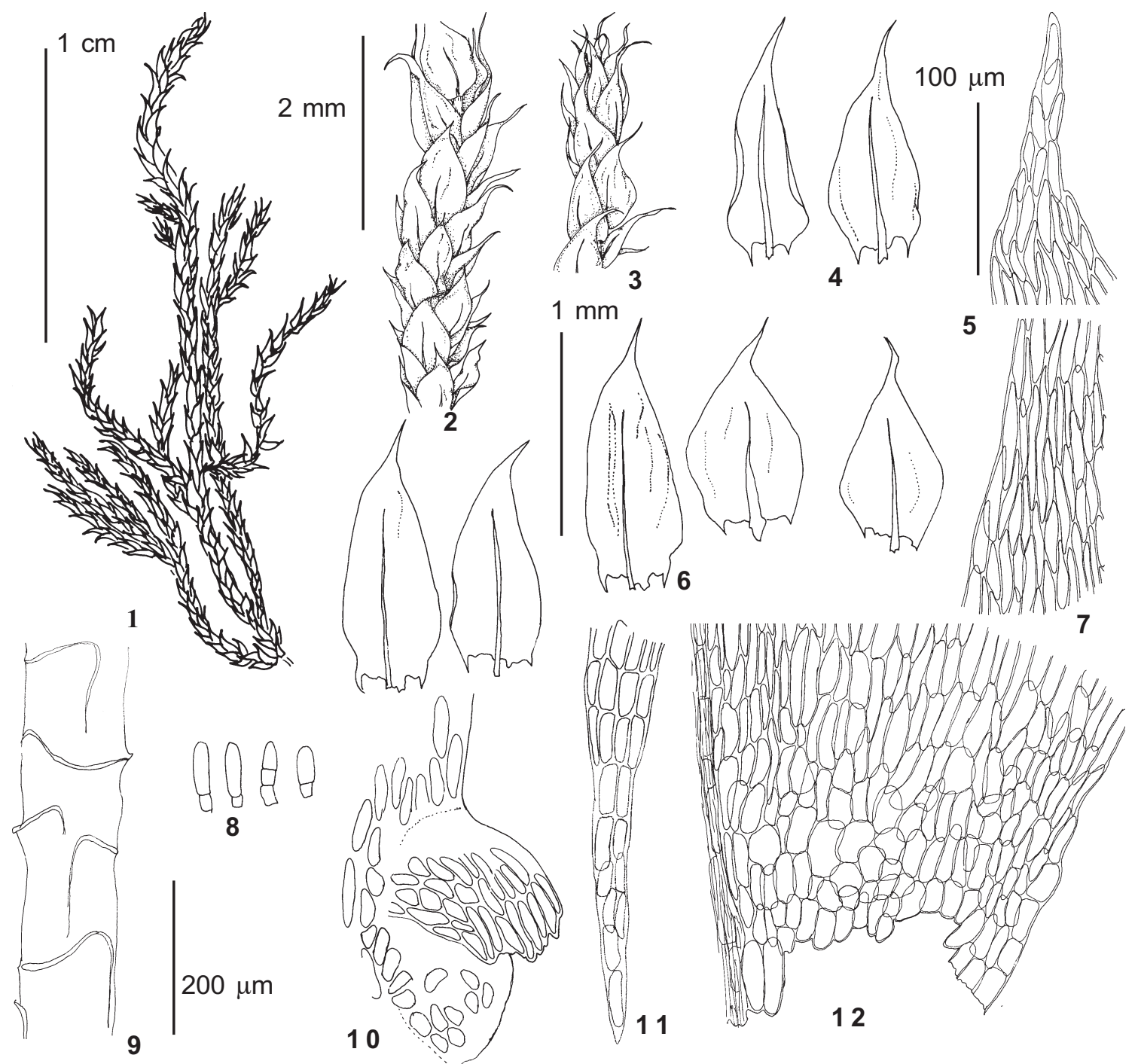

Fig. 24. Brachythecium glaciale B. S. G. (from Grano, H-BR 0526010): 1 - habit; 2 - middle part of stem; 3 - upper part of stem; 4 - branch leaves; 5 - upper laminal cells of stem leaf; 6 - stem leaves; 7 - median laminal cells of stem leaf; 8 - axillary hairs; 9 - stem leaf insertions; 10 - branch initial with pseudoparaphyllia; 11 - leaf decurrency; 12 - basal cells of stem leaf. Scale bars: $1 \mathrm{~cm}$ for $1 ; 2 \mathrm{~mm}$ for $2-3 ; 1 \mathrm{~mm}$ for 4,$6 ; 200 \mu \mathrm{m}$ for $9 ; 100 \mu \mathrm{m}$ for $5,7-8,10-12$.

nana shrubs, on soil with Rhytidiadelphus squarrosus, Brachythecium erythrorrhizon ssp. asiaticum, etc.

Specimens examined: Bayas Creek, in middle course $850 \mathrm{~m}(16 / 9), 1300 \mathrm{~m}(16 / 44) ;$ Kairu Creek, 8 km upstream $1000 \mathrm{~m}$ (15/10a); Kairu-Bazhi Peak $2050 \mathrm{~m}$ (13/ 107a; 13/114a; 13/115a); Shavla River, upper course (Kreps 16.VIII.1937 LE!)

sect. Reflexa (Limpr.) Broth., Nat. Pfl. 1(3): 1145. 1909. - "group Salebrosa" Limpr., Laubm. 3: 62.1895.

Plants slender to relatuvely robust; stem leaves broadly ovate or ovate-triangular to ovate-lanceolate, broadly and longly decurrent, not or slightly plicate; laminal cells broad to narrow; seta mammil- lose, but sometimes indistinctly so; capsule inclined to horizontal or cernuous.

Brachythecium glaciale B.S.G., Bryol. Eur. 6: 15. 542. 1853.

Fig. 24

Plants green to brownish-green. Stem irregularly branched, branches julaceous, to $20 \mathrm{~mm}$ long; sympodial branching rather frequent, sometimes plans almost unbranched. Pseudoparaphyllia triangular to triangular-truncate. Axillary hairs 23 -celled, to $40 \times 10 \mu \mathrm{m}$, apical cell to $30 \mu \mathrm{m}$ long. Stem leaves erect, 1.3-2.0(2.6) x 0.6-1.0(1.3) mm, ovate-lanceolate, abruptly acuminate, widest at about $1 / 3$ of leaf length; strongly concave, not or indistinctly plicate; at base longly decurrent; 

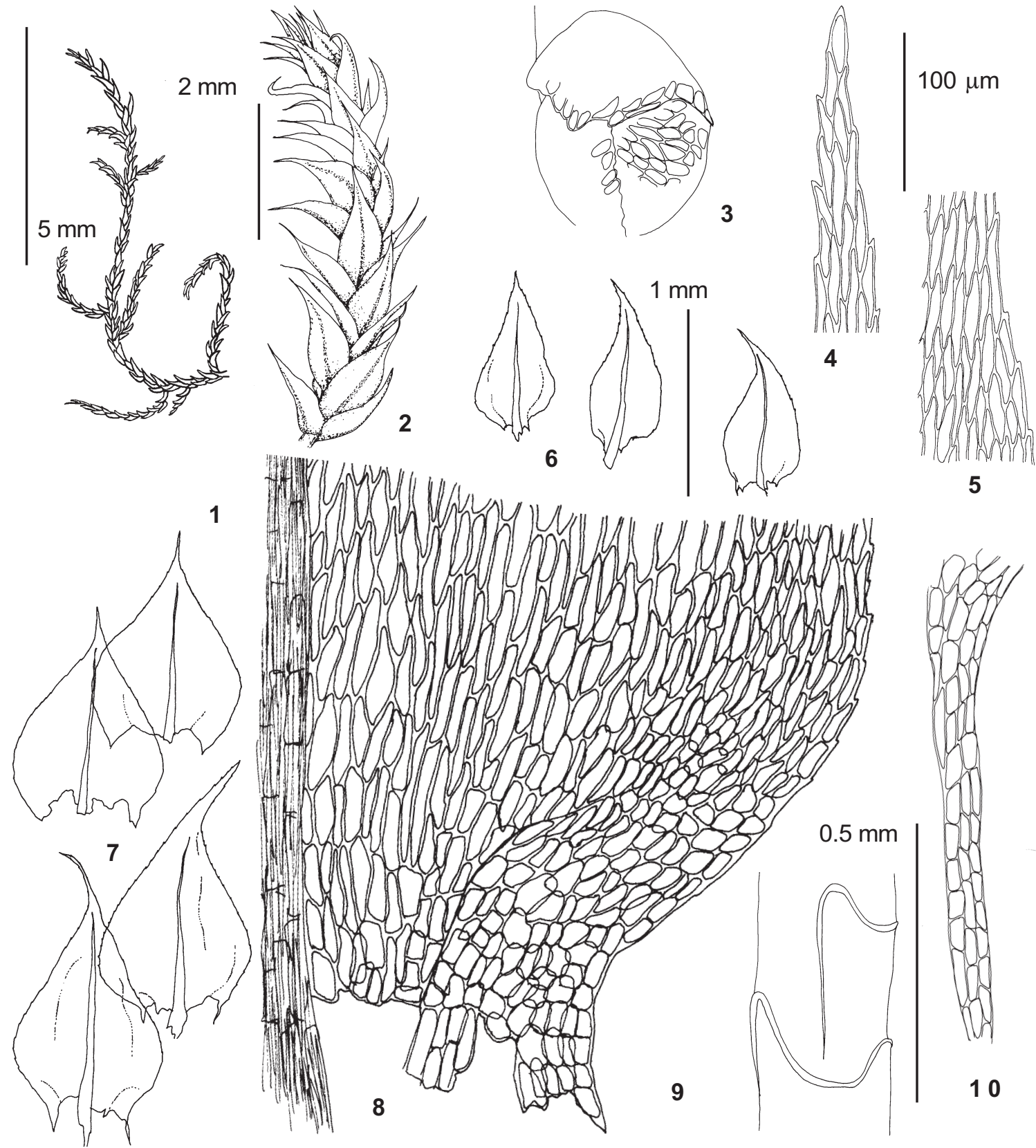

Fig. 25. Brachythecium dovrense (Limpr.) Amman (from Ignatov, 0/449): 1 - habit; 2 - upper part of stem; 3 branch initial with pseudoparaphyllia; 4 - upper laminal cells of stem leaf; 5 - median laminal cells of stem leaf; 6 branch leaves; 7 - stem leaves; 8 - basal cells of stem leaf; 9 - stem leaf insertions; 10 - leaf decurrency. Scale bars: $5 \mathrm{~mm}$ for $1 ; 2 \mathrm{~mm}$ for $2 ; 1 \mathrm{~mm}$ for $6-7 ; 0.5 \mathrm{~mm}$ for $9 ; 100 \mu \mathrm{m}$ for $3-5,8,10$.

costa reaching $0.6-0.7$ of leaf length, $50-55 \mu \mathrm{m}$ wide at base; margin subentire. Median laminal cells $30-70(100) \times 7-9(12)(5-7 / 1.5-2.5) \mu \mathrm{m}$; at base wider in 4-7 rows, in leaf corners subquadrate cells (12-14 $\mu \mathrm{m}$ wide) forming \pm well-differentiated square group. Branch leaves narrower; costa not ending in spine. Gametangia and sporophytes not found in Altaian plants. [Autoicous.
Seta mamillose].

This species differs from other Altaian species in its \pm julaceous foliage, very concave leaves with short acumina, relatively small alar group, consisting of cells that are smaller than other basal cell. Three collections have \pm medium-sized plants, but in fourth specimen plants are ro- 


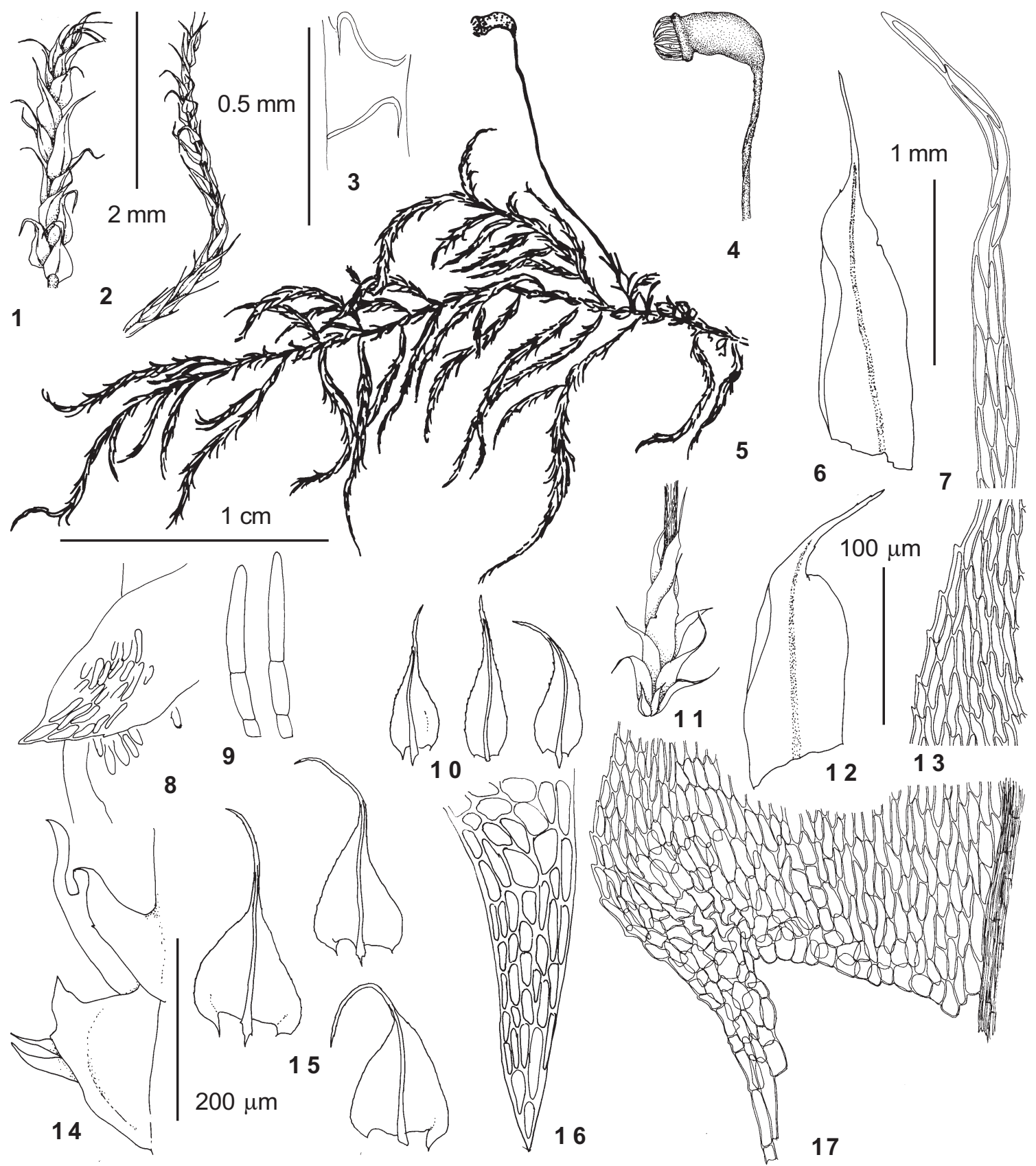

Fig. 26. Brachythecium reflexum (Starke) B. S. G. (from Ignatov 0/1637): 1 - upper part of stem; 2 - branch; 3 stem leaf insertions; 4 - capsule; 5 - habit; 6, 12 - perichaetial leaves; 7 - upper laminal cells of stem leaf; 8 , 14 branch initials with pseudoparaphyllia; 9 - axillary hairs; 10 - branch leaves; 11 - perichaetium; 13 - median laminal cells of stem leaf; 15 - stem leaves; 16 - leaf decurrency; 17 - basal cells of stem leaf. Scale bars: $1 \mathrm{~cm}$ for $5 ; 2 \mathrm{~mm}$ for $1,2,4,11 ; 1 \mathrm{~mm}$ for $6,10,12,15 ; 0.5 \mathrm{~mm}$ for $3 ; 200 \mu \mathrm{m}$ for $14 ; 100 \mu \mathrm{m}$ for $7-9,13,16-17$.

bust, and have larger leaves and cells (its dimensions are given in brackets). This specimens grew in the upper alpine belt, in the water from a melting late snow-bed.

Distribution: Arctic and alpine species, known from most mountains of Eurasia, southward to the Himalayas and Sichuan. In South Siberia and southern part of the Russian Far East it is a rare species. In Altai it has been collected only in the alpine belt of Central Altai.

Specimens examined: Katunskij Range 1900 m (Gra- 
no 1.VIII.1915 H-BR!); Kobiguayuk Creek 2300 m (0/ 292), 2800 m (0/444); Terekntinskij Range 2000 m (Keller 31.VII.1909 H!).

Brachythecium dovrense (Limpr.) Amann, Fl. Mouss. Suisse 2: 308. 1919.

Fig. 25

Brachythecium glaciale var. dovrense Limpr., Laubm. Deutschl. 3: 112. 1896. - Brachytecium reflexum var. dovrense (Limpr.) Loeske, Stud. Morph. Syst. Laubm. 182. 1910.

Plants green to brownish-green. Stem irregularly branched, branches julaceous, to $6 \mathrm{~mm}$ long; sympodial branching rather frequent. Pseudoparaphyllia triangular to triangular-truncate. Stem leaves erect, 1.5-1.7 x 0.9-1.1 mm, ovate-lanceolate or triangular, abruptly acuminate, widest at about $1 / 3$ of leaf length, at base suddenly narrowed, forming submarginal concave groups; strongly concave, indistinctly plicate; at base very longly decurrent; costa reaching $0.8-0.9$ of leaf length, ca. $55 \mu \mathrm{m}$ wide at base; margin subentire. Median laminal cells 3055 x 8-11 (6-9/1.5-2.5) $\mu \mathrm{m}$; at base slightly wider, in leaf corners near the margin cells subquadrate, 10-13 $\mu \mathrm{m}$ wide, in concave submarginal group moderately to strongly enlarged (to $18 \mu \mathrm{m}$ wide) and well-differentiated from cells above. Branch leaves narrower; costa not ending in spine. Gametangia and sporophyte not found in Altaian plants. [Autoicous. Seta mammillose].

Limpricht (1895) and Nyholm (1965) considered $B$. dovrense as a variety of $B$. glaciale, Loeske (1910) - as a variety of $B$. reflexum, Amman (1918) and Schljakov (1952) - as a separate species. In Altai both $B$. glaciale and $B$. dovrense are very rare species, so it is impossible to contribute much to the problem of the status of B. dovrense. However Brachythecium dovrense occurs in some areas where $B$. glaciale is rare or absent (Altai, Chukotka Afonina \& Czernyadjeva, 1995) and this differences in distribution suggest that they should be treated as separate species.

Distribution: Brachythecium dovrense has been reported from Central Europe, Skandinavia, Kola Peninsula and Chukotka. In Altai it was found only once on wet clayish bank in the lower alpine belt.

Specimens examined: Bayas Lake 2050 m (0/449).

Brachythecium reflexum (Starke) B.S.G., Bryol. Eur. 6: 12 (fasc. 52-54. Monogr. 8). 1853.

Figs. 26, 27

Hypnum reflexum Starke in Weber et D. Mohr, Bot. Taschenb. 306. 1807.

Plants deep green, rarely yellow-green. Stem regularly pinnately branched, with branches to 8 $\mathrm{mm}$ long, and with numerous sympodial branches which make the tufts of plant rather thick. Pseudoparaphyllia triangular. Axillary hairs 3-celled, to $120 \times 10 \mu \mathrm{m}$, apical cell $60 \mu \mathrm{m}$ long. Stem leaves 1.0-1.4 x 0.5-0.6 mm, deltoid-ovate, abruptly longacuminate, widest at ca. $1 / 7$ of leaf length; plane except in subbasal region, not plicate; at base longly and broadly decurrent; costa reaching 0.8-0.95 of leaf length, 40-50 $\mu \mathrm{m}$ wide at base; margin serrate to serrulate throughout, or in acumen entire. Median laminal cells 25-60 x 7-11 (5.5-9.5/1.02.0) $\mu \mathrm{m}$; towards base wider and forming extensive laxly areolated area, in leaf corners moderately to distinctly enlarged (to $20 \times 15 \mu \mathrm{m}$ ), forming more transparent regions. Branch leaves lanceolate to ovate-lanceolate; margin more strongly serrate, costa ending in distinct spine. Perichaetial leaves abruptly acuminate, outer and inner (but sometimes not middle perichaetial leaves!) with weak costa reaching at least 0.9 of leaf length. Seta to $1.1 \mathrm{~cm}$, mammillose. Capsule 1.0-1.3 mm long, inclined to horizontal. Operculum conic. Peristome complete, cilia 2-3, appendiculate. Spores 18-21 $\mu \mathrm{m}$, papillose.

This species is rather homogeneous in Altai, but plants of two sterile collections from Katunskij Range (Fig. 27) are markedly larger (their character states are not included in the above description). They have reflexed to squarrose stem leaves, 1.6-1.9 × $1.0 \mathrm{~mm}$, with laminal cells $20-45 \times 6-13 \mu \mathrm{m}$, and branch leaves that are also strongly reflexed. Habitually these plants resemble the Japanese endemic B. brotheri Par. (though this species was reported also from China, all so-named collections seen by me from mainland Asia do not belong to this species). However $B$. brotheri differs in having non-decurrent leaves and a costa that ends somewhat above mid-leaf, whereas the Altaian plants have a costa that nearly reaches the apex, and leaves that are decurrent as in normal $B$. reflexum.

Brachythecium reflexum is easy to recognize by its relatively small plants with broadly-triangular leaves and a costa that disappears in the leaf acumen. A problem can be posed only by $B$. starke $i$ and rarely also by B. populeum, both species with long costa. Their differences are discussed under the latter two species.

Distribution: Brachythecium reflexum is widely distributed throughout the Northern Hemisphere in the boreal and northern temperate zones, with scattered localities in the Arctic and the high mountains. In Altai it has been found from the forest to 


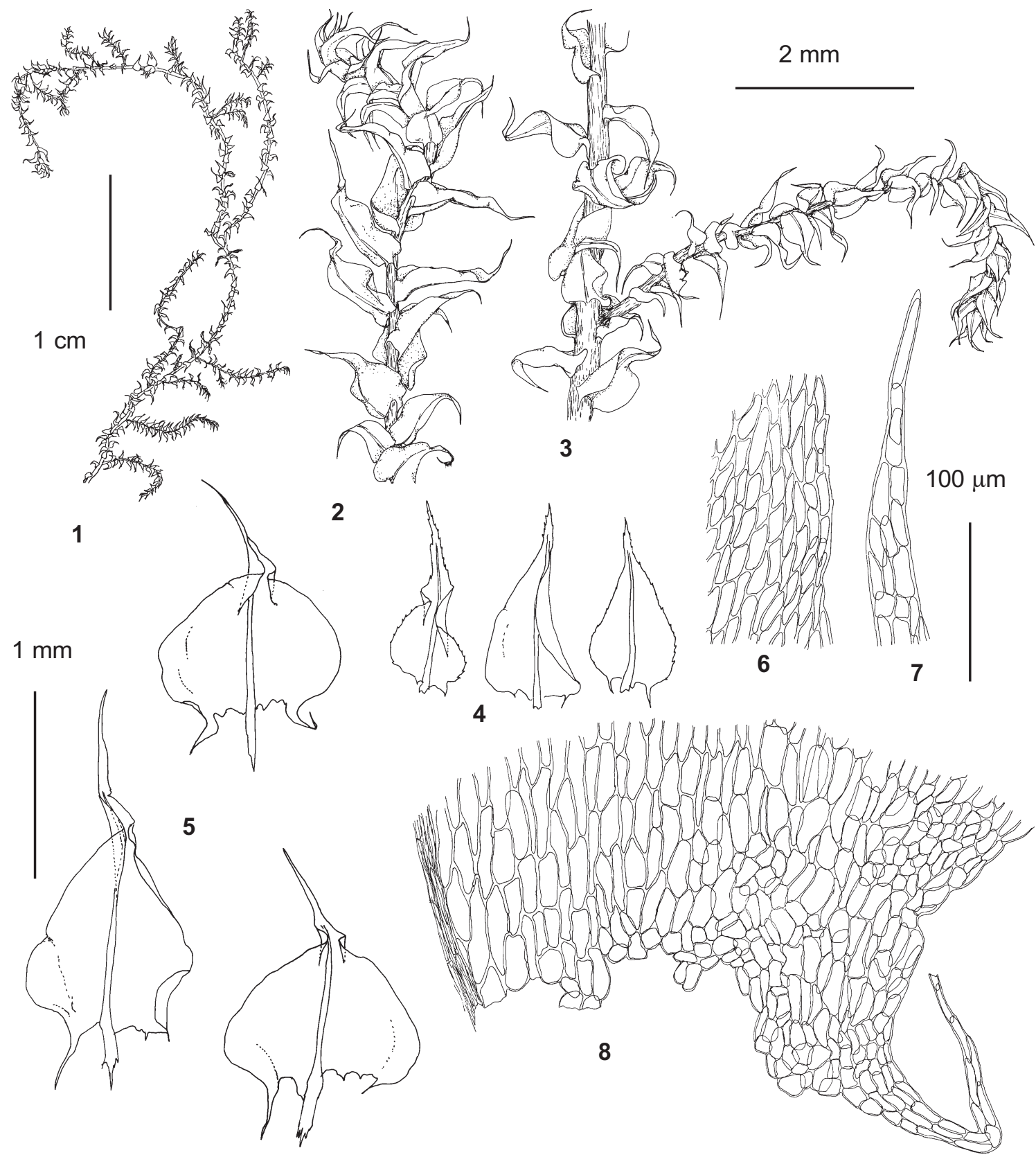

Fig. 27. Brachythecium reflexum (Brid.) B. S. G. (from Kaitanak, Reczan \& A. Krylov, ): 1 - habit; 2 - upper part of stem; 3 - stem and branch; 4 - branch leaves; 5 - stem leaves; 6 - median laminal cells of stem leaf; 7 - upper laminal cells of stem leaf; 8 - basal cells of stem leaf. Scale bars: $1 \mathrm{~cm}$ for $1 ; 2 \mathrm{~mm}$ for $2-3 ; 1 \mathrm{~mm}$ for $4-5 ; 100 \mu \mathrm{m}$ for 6-8.

subalpine zones, mostly on rotten logs, sometimes on living trunks (Salix, Betula) and on rocks.

Specimens examined: Ayukol $1450 \mathrm{~m}(0 / 1637)$; Bolshoye Istyube Creek $470 \mathrm{~m}(18 / 88)$; Chiri Creek, 0.5 km upstream $450 \mathrm{~m}(17 / 72)$; Kairu Creek, 16 km upstream 1400 m (14/50); Kairu-Bazhi Peak 2050 m (13/105); Kaitanak Creek 1500 m (Krylov \& Reczan 10.VII.1968 LE!); Karakol Lakes 1900 m (28/117; 28/163); Katunskiye Belki, to Agafonikha 1900 m (Krylov \& Reczan
20.VII.1968 LE!); Kobukhtushka $440 \mathrm{~m}$ (Zolotukhina 28.III.1988); Ok-Porok Creek, at mouth $450 \mathrm{~m}$ (Zolotukhin 14.X.1988); Uedinennoye Lake $880 \mathrm{~m}(0 / 1636)$.

Brachythecium starkei (Brid.) B.S.G., Bryol. Eur. 6: 14 (fasc. 52-54. Monogr. 10). 1853. Fig. 28

Hypnum starkei [starkii] Brid., Muscol. Recent. 2(2): 107. 1801.

Plants green to yellow-green. Stem prostrate, \pm reg- 


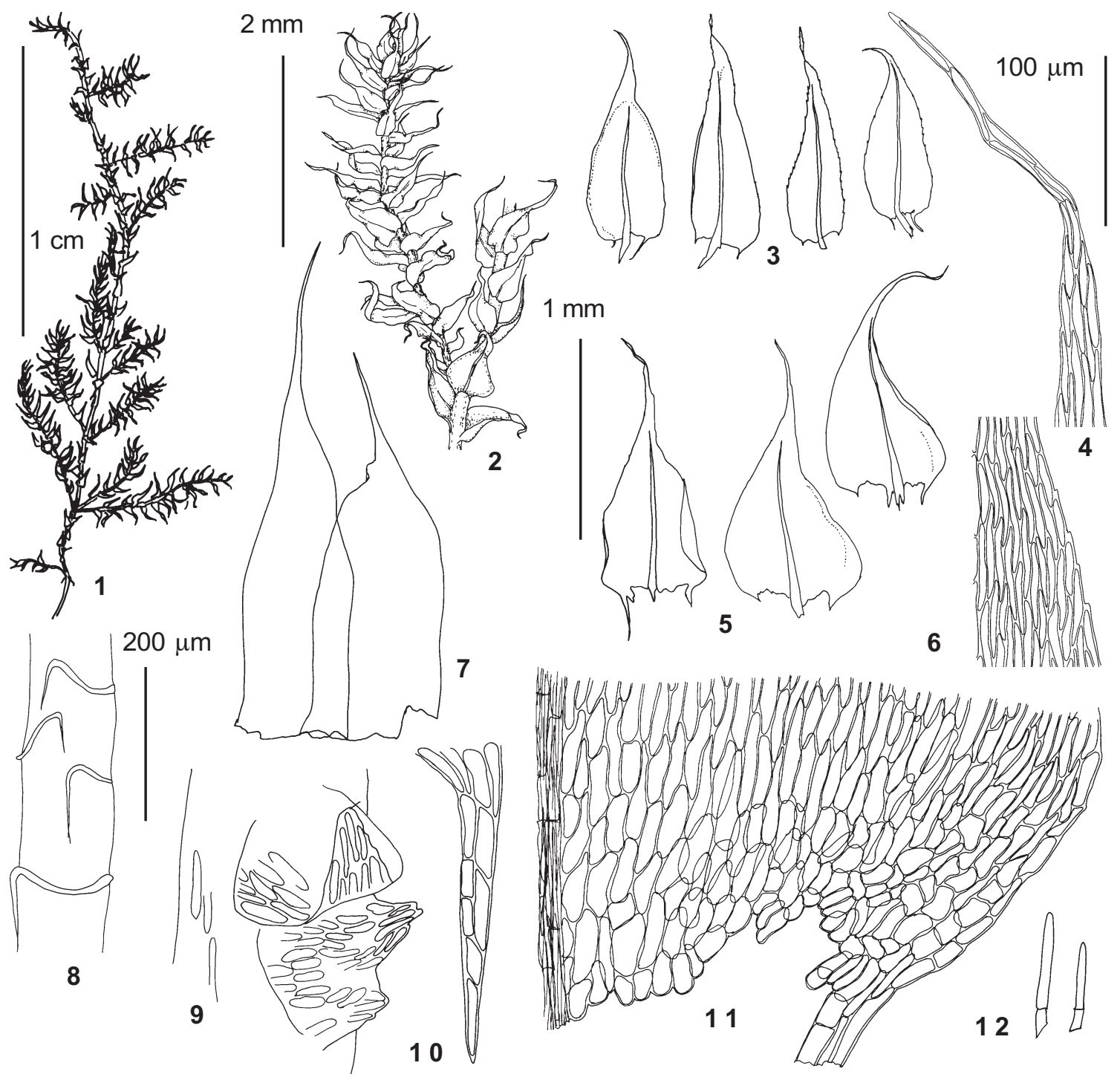

Fig. 28. Brachythecium starkei (Brid.) B. S. G. (from Ignatov 26/13): 1 - habit; 2 - part of stem with branch; 3 - branch leaves; 4 - upper laminal cells of stem leaf; 5 - stem leaves; 6 - middle laminal cells of stem leaf; 7 perichaetial leaves; 8 - stem after leaf detaching showing lines of leaf insertion; 9 - branch initial with pseudoparaphyllia; 10 - leaf decurrency; 11 - basal cells of stem leaf; 12 - axillary hairs. Scale bars: $1 \mathrm{~cm}$ for 1; $2 \mathrm{~mm}$ for $2 ; 1 \mathrm{~mm}$ for $3,5,7 ; 200 \mu \mathrm{m}$ for $8 ; 100 \mu \mathrm{m}$ for $4,6,9-12$.

ularly pinnately branched; branches with subjulaceous foliage, to $6 \mathrm{~mm}$ long. Pseudoparaphyllia triangular. Axillary hairs 2-celled, to 70 x $7 \mu \mathrm{m}$, apical cell $50 \mu \mathrm{m}$ long. Stem leaves $1.3-1.5$ x 0.7-0.75 mm, ovatetriangular to \pm ovate, abruptly acuminate, widest below $1 / 7$ of leaf length; slightly concave and nonplicate; at base suddenly narrowed and narrowly decurrent; costa reaching $0.65-0.9$ of leaf length, 25$30 \mu \mathrm{m}$ wide at base; margin serrulate up to the widest part of leaf, sometimes indistinctly so. Laminal cells flexuose, 35-70 x 4.0-6.0 (3-5/1.0) $\mu \mathrm{m}$; towards base cells wider in 5-7 rows; in leaf corner subquad- rate, forming indistinct alar group. Branch leaves lanceolate, gradually acuminate; costa disappearing in acumen, if slightly shorter ending in spine. Autoicous, perigonia and perichaetia on stem. Perichaetial leaves longly acuminate, ecostate or with short costa. Seta to $1.3 \mathrm{~mm}, \pm$ lowly mammillose. Capsule $1.5 \mathrm{~mm}$ long, inclined. Operculum conic. Annulus deciduous. Peristome complete, cilia nodose, rarely shortly appendiculate. Spores $12-14 \mu \mathrm{m}$.

This species is intermediate in its characters between $B$. oedipodium and B. reflexum. At first only two taxa were recognized in this 
complex. Following Bruch \& al. (1855), they were named $B$. reflexum (for the smaller species) and B. starkei (for the larger species). Lindberg (1879) recognized three species in this complex: Hypnum reflexum, $H$. starke $i$ and H. curtum Lindb. (=B. starkei sensu B. S. G., B. curtum (Lindb.) Limpr.). Later most authors followed this treatment, but they often named $B$. curtum as B. starkei var. explanatum Mönk., Laubm. Eur. 819. 1927. Pii ppo (1983) lectotypifyed $B$. starkei, and found that $B$. oedipodium (Mitt.) Jaeg.is an earlier name for $B$. curtum.

Pii ppo $(1983,1984)$ also revised the differences between these species. According to her treatment, $B$. starkei differs from $B$. oedipodium in (1) a smaller size; (2) shorter cells in the stem leaves; (3) a costa that disappears in the acumen in both stem and branch leaves. Brachythecium starkei differs from $B$. reflexum in (1) a lighter color of the plants; (2) less curved branches; (3) longer laminal cells in the stem leaves (up to $80 \mu \mathrm{m}$ vs. up to $50 \mu \mathrm{m}$ ); (4) longer and non-rectangular laminal cells in the branch leaves (in $B$. reflexum short and rectangular).

In Altai, as well as in other boreal regions of Russia, there is a little problem to distinguish $B$. oedipodium from $B$. starke $i$ because the costa ends at $2 / 5-3 / 5$ of leaf length, the plants are usually more robust, have a very lax basal leaf areolation, and usually complanate branches. Sometimes $B$. oedipodium develops stoloniferous-like shoots, with leaves about half as large as usual, but they always have a costa ending in mid-leaf.

On the other hand, the pair B. reflexum $-B$. starke $i$ is exceedingly troublesome. When growing on tree trunks in deciduous forests, plans of $B$. reflexum are small, with short laminal cells, and can easily recognized by the naked eye. However, in wet spruce taiga and in subalpine communities plants of $B$. reflexum are medium-sized, equal to or somewhat larger than the average size of $B$. starkei. All transitions exist between these larger phenotypes of $B$. reflexum and its smaller phenotypes. In the larger pheno- types of $B$. reflexum the length of the stem leaf laminal cells is about the same as in $B$. starke $i$ (50-80 $\mu \mathrm{m})$, so this character can not differentiate these two species. Someillustrations in Piippo (1983, figs. $13 \& 18$ ) demonstrate the same fact. These robust phenotypes of $B$. reflexum are often pale green. The presence of curved branches is also not a completely reliable character. It occurs also in $B$. starke $i$, though more rarely than in $B$. reflexum.

The length of costa in the inner perichaetial leaves is useful, but not completely reliable charachter: in $B$. reflexum it has been found always long (cf. Fig. 25), while Altaian specimens of $B$. starke $i$ has short to inconspicuous costa. However in one collection from the Urals I have seen $B$. starke $i$ with costa reaching above mid-leaf.

I found only two characters which are useful to segregate $B$. starke $i$ from $B$. reflexum: (1) the branch leaves are spreading (vs. appressed to erect in $B$. reflexum) and (2) the laminal cells are flexuose and relatively narrower (in stem leaves - 4-6 $\mu \mathrm{m}$ vs. 7-10(13) $\mu \mathrm{m}$ in $B$. reflexum). In smaller phenotypes of $B$. reflexum the cells are as narrower and similar to in some plants of $B$. starkei, but in these case they are also much shorter. The length to width ratio of the lumen of the laminal cells in $B$. starke $i$ is $8-15: 1$, vs. 4-10:1 in B. reflexum.

As circumscribed above, $B$. starke $i$ is a relatively rare species, so the number of observations and measurements were limited (14 in Altai, 20 in European Russia, 15 in Caucasus). It cannot be excluded that studies of more material may reveal no absolute hiatus between $B$. reflexum and $B$. starkei.

Confusion of $B$. starke $i$ with the other species in Altai is unlikely, but in European Russia some specimens referred to $B$. starke $i$ have narrow branch leaves and the plants superficially resemble $B$. velutinum. However the latter species has the small alar cells whereas in $B$. starkei they are always enlarged.

Distribution: Circum-Holarctic species, occurring mostly in the boreal and hemiboreal zones and the oreo-boreal and oreo-hemiboreal belts in more southern mountains. Due to long-term confusion with $B$.

Fig. 29. Brachythecium oedipodium (Mitt.) Jaeg. (from Ignatov 0/1635): 1 - capsule; 2, 7 - habit; 3 - stem leaf insertions; 4 - axillary hairs; 5 - branch initial with pseudoparaphyllia; 6 - upper laminal cells of stem leaf; 8 - upper part of stem; 9 - median laminal cells of stem leaf; 10 - inner perichaetial leaves; 11 - outer perichaetial leaf; 12 - perichaetium; 13 - basal cells of stem leaf; 14 - stem leaves; 15 - branch leaves; 16 - leaf decurrency. Scale bars: $1 \mathrm{~cm}$ for 2,$7 ; 2 \mathrm{~mm}$ for $1,8,12 ; 1 \mathrm{~mm}$ for $10-11,14-15 ; 0.5 \mathrm{~mm}$ for $3 ; 100 \mu \mathrm{m}$ for $4-6,9,13,16$. 


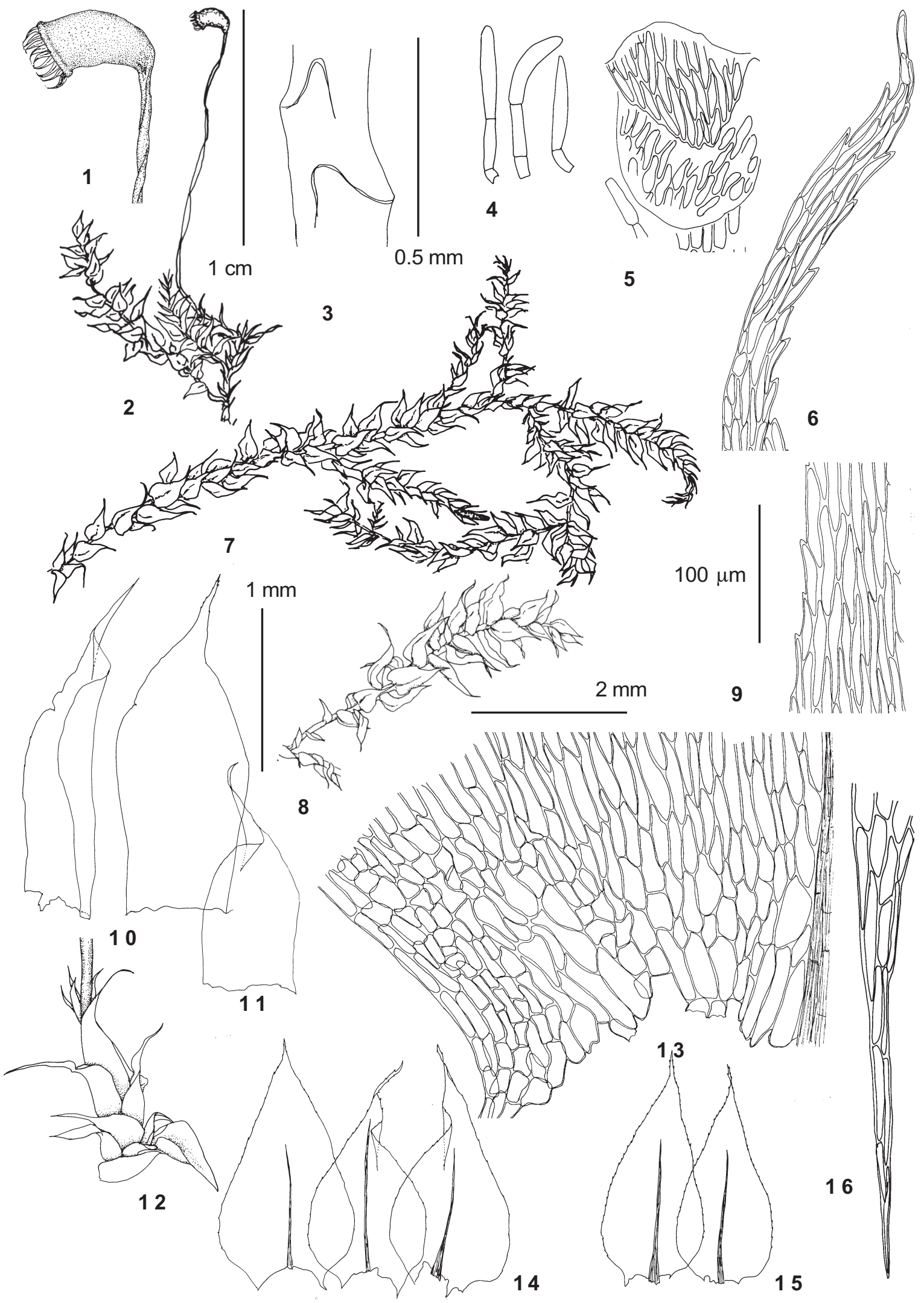


oedipodium, many records of $B$. starkei belong to that species. In Altai it typically grows in conifer forests, on rotten logs and litter, and sometimes on inclined trunks of Betula and on rocks.

Specimens examined: Ayukol $1000 \mathrm{~m}$ (0/1676; 0/ 1681), $1400 \mathrm{~m}(0 / 442)$; Bayas Creek, at mouth $600 \mathrm{~m}$ (0/1638); Bolshoi Shaltan Creek $520 \mathrm{~m}(0 / 1677)$; Elekmonar Creek, 5 km upstream $700 \mathrm{~m}$ (26/13); KairuBazhi Peak $2050 \mathrm{~m}(13 / 107)$; Kamga Creek, 9 km upstream $520 \mathrm{~m}(0 / 1675)$; Kobukhta $700 \mathrm{~m}(0 / 252)$; Seminskij Pass $1800 \mathrm{~m}$ (25a/1); Uedinennoye Lake $880 \mathrm{~m}$ (0/1689), $1030 \mathrm{~m}(0 / 1687)$; Ust-Sema $500 \mathrm{~m}$ (24/145).

Brachythecium oedipodium (Mitt.) Jaeg., Ber. Thatigk. St. Gallischen Naturwiss. Ges. 187677: 330 (Gen. Sp. Musc. 2: 396. 1878. Fig. 29

Hypnum oedipodium Mitt., J. Proc. Linn. Soc., Bot. 8: 32. 1865.

Plants deep green to light- or yellowish green. Stem \pm regularly pinnate, branches to $10 \mathrm{~mm}$ long, usually \pm complanate (when plants grow plagiotropically in pure mats on litter) or sometimes subjulaceous (when plants grow \pm orthotropically, e. g. among dense herbs). Psuedoparaphyllia triangular. Axillary hairs 2-3-celled, 110 x $11 \mu \mathrm{m}$. Stem leaves patent, 1.5$2.0 \times 0.8-1.1$, ovate to ovate-triangular, shortly gradually acuminate, widest at about $1 / 7$ of leaf length; slightly concave and indistinctly plicate; longly and narrowly decurrent; costa reaching $0.4-0.75$ of leaf length, $40 \mu \mathrm{m}$ wide at base; margin serrulate to the widest part of leaf. Median laminal cells 70-100 x 8$11(7-10 / 1) \mu \mathrm{m}$; towards leaf base cells wider, forming extensive laxly areolated area, in leaf corner little differentiated. Branch leaves narrower; costa ending in long spine. Autoicous. Perichaetial leaves \pm abruptly and relatively shortly acuminate. Seta to $1.8 \mathrm{~cm}$, mammillose. Capsule $1.8 \mathrm{~mm}$ long, horizontal to pendent. Operculum conic. Peristome complete, cilia nodose. Spores 13-15 $\mu \mathrm{m}$.

Though Brachythecium oedipodium is very variable in size and appearance in Altai, it is easily known by its (1) non-plicate, ovate to ovate-triangular leaves; (2) relatively short costa, usually ending at 0.4-0.5 of leaf length; 3) lax homogeneous basal cells; 4) frequent presence of sporophytes. Brachythecium rutabulum spcimens from deeply shaded habitats may have nearly plane leaves and a habit that superficially resembles $B$. oedipodium. A reliable difference in this case is the spinulose end of the branch leaf costa of $B$. oedipodium vs. the smooth costa end in B. rutabulum.

Distribution: This species has a circumboreal distribution and occurs mainly in the southern boreal and hemiboreal zones, though it reaches the northern boreal zone. In temperate regions of Eur- asia $B$. oedipodium occurs in mountains (Central and South Europe, Caucasus, SW China). In Altai $B$. oedipodium occurs in the forest and subalpine belts, on soil rich in humus in conifer forests, under ferns and in tall-herb meadows.

Specimens examined: Bolshoye Istyube Creek $470 \mathrm{~m}$ (18/44; 18/9); Chemal Creek, $3 \mathrm{~km}$ upstream $450 \mathrm{~m}$ (34/180); Chiri $450 \mathrm{~m}(17 / 37)$; Kairu Creek, 16 km upstream $1400 \mathrm{~m}(14 / 38) ;$ Kairu Creek, 8 km upstream $1000 \mathrm{~m}(15 / 10 ; 15 / 112) ;$ Kamga Creek, at mouth 450 m (Zolotukhin 20.X.1988); Karakol Lakes 1900 m (28/ 112); Kyga River, 2 km upstream $600 \mathrm{~m}$ (0/3006); Saluru Creek, in middle course $2050 \mathrm{~m}(36 / 291)$; UstSema 500 m (24/146); Yailyu 460 m (0/1635).

Sect. Cirriphyllopsis (Broth.) Takaki, J. Hattori Bot. Lab. 15: 22. 1955. - Brachythecium subg.Cirriphyllopsis Broth.,Nat.Pfl.1(3): 1147. 1909.

Plants relatively small to medium-sized; stem leaves narrowly lanceolate to ovate-lanceolate, concave, non-plicate or with submarginal plicae; branch leaves straight or falcate, with costa not ending in spine; laminal cells narrow, thick-walled; basal cells not translucent; seta mammillose to indistinctly so; capsule inclined to horizontal.

Brachythecium populeum (Hedw.) B.S.G., Bryol. Eur. 6: 7. 535. $1853 . \quad$ Fig. 30

Hypnum populeum Hedw., Sp. Musc. Frond. 270. 70 f. 1-6. 1801.

Plants green to yellow-brownish. Stem regularly pinnately branched, branches subjulaceous, up to 6 $\mathrm{mm}$ long. Pseudoparaphyllia triangular. Axillary hairs 2-3-celled, to $45 \times 7 \mu \mathrm{m}$, apical cell to $25 \mu \mathrm{m}$ long. Stem leaves $2.0 \times 0.9-1.0 \mathrm{~mm}$, lanceolate to ovatelanceolate, \pm gradually acuminate, widest ca. $1 / 7$ of leaf length; slightly concave and with submarginal plicae; at base longly and narrowly decurrent; costa reaching $0.8-0.9$ of leaf length, $40-60 \mu \mathrm{m}$ wide at base; margin subentire to indistinctly serrulate. Median laminal cells $30-60 \times 7-8(4.0-5.5 / 2.0-2.5) \mu \mathrm{m}$; towards base wider in 2-4 rows, in leaf corner subquadrate cells forming opaque group, which is indistinctly delimited from surrounding cells. Branch leaves narrower; costa not ending in spine. Perichaetial leaves abruptly longly acuminate, with short costa. Seta to $1.3 \mathrm{~cm}$, mammillose. Capsule $1.5 \mathrm{~mm}$ long, inclined. Operculum conic. Peristome complete, cilia appendiculate. Spores 13-16 $\mu \mathrm{m}$.

Brachythecium populeum is easy to identify due to its long costa. A long costa occurs in $B$. reflexum, which is usually easy to differentiate from $B$. populeum by its broadly ovate to deltoid leaves, broad decurrencies, and lax, transparent cells of the leaf base. Common mesic phenotypes of B. populeum (cf. Fig. 30) 


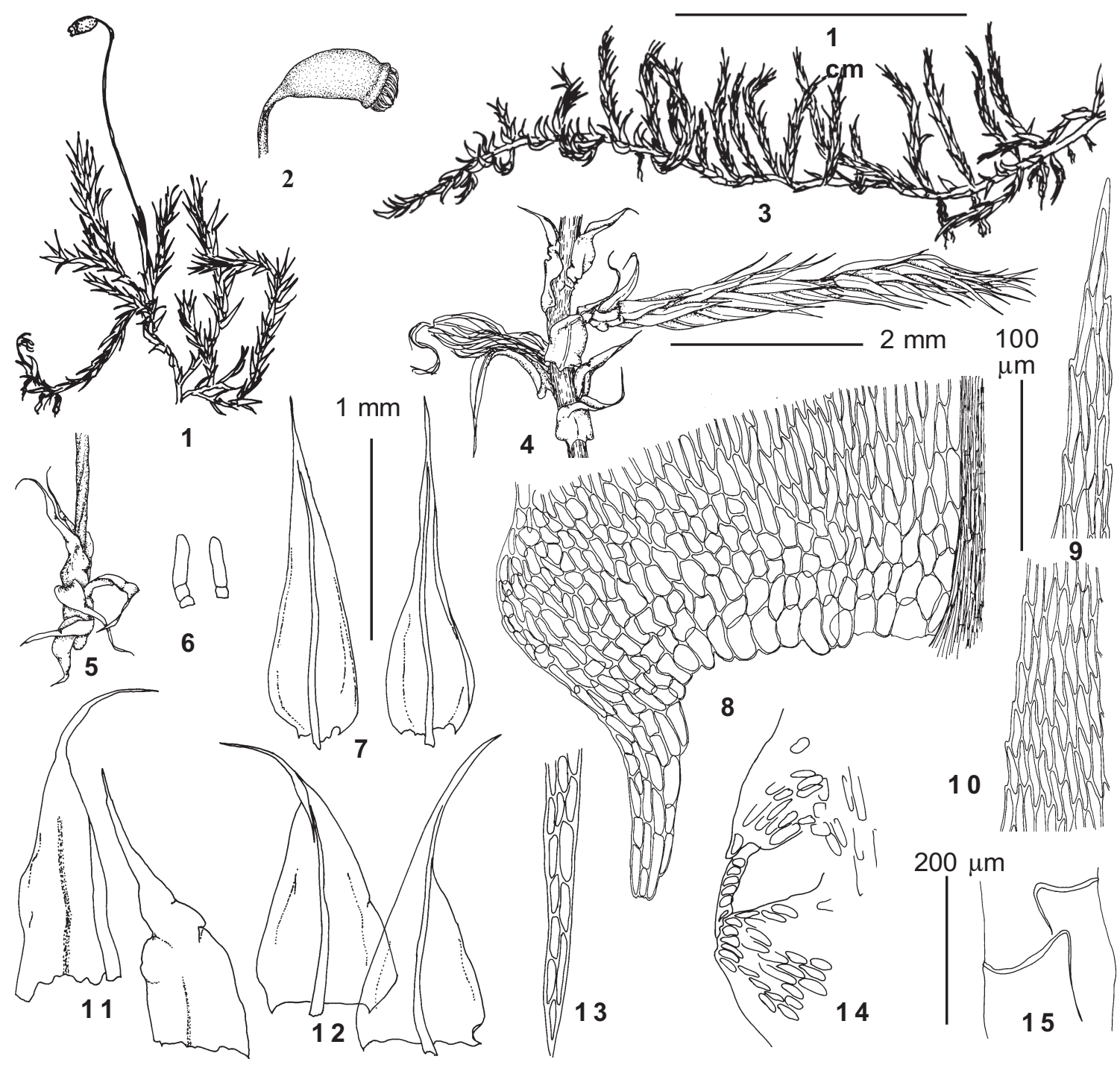

Fig. 30. Brachythecium populeum (Hedw.) B. S. G. (from Ignatov 1/16): 1, 3 - habit; 2 - capsule; 4 - part of stem with branch; 5 - perichaetium; 6 - axillary hairs; 7 - branch leaves; 8 - basal cells of stem leaf; 9 - upper laminal cells of stem leaf; 10 - median laminal cells of stem leaf; 11 - perichaetial leaves; 12 - stem leaves; 13 - leaf decurrency; 14 - branch initial with pseudoparaphyllia; 15 - stem leaf insertions. Scale bars: $1 \mathrm{~cm}$ for 1,$3 ; 2 \mathrm{~mm}$ for $2,4-5 ; 1 \mathrm{~mm}$ for $7,11-12 ; 200 \mu \mathrm{m}$ for $15 ; 100 \mu \mathrm{m}$ for $6,8-10,13$.

have lanceolate to broadly-lanceolate stem leaves. However, plants of B. populeum from wet habitats (on boulders in wet forests or swamps, etc.) have sometimes much broader leaves with laxly areolate leaf corners and relatively short laminal cells. These phenotypes are attributed to $B$. populeum because their alar cells though enlarged, are rich in chloroplasts and not translucent.

Distribution: Brachythecium populeum is widespread in the Holarctic except the Arctic and northernmost part of the boreal zone. There are many records from the high mountains of Africa. In Altai it is common on rocks (both basic and acidic) and trunks (especially Salix) at lower elevations, but it occurs sporadically in the boreal to subalpine belts.

Specimens examined: Artybash $450 \mathrm{~m}(22 / 1)$; Ayukol 800 m (0/1643), 1000 m (0/1640); Bayas Creek, in middle course $750 \mathrm{~m}(16 / 1)$; Bele $500 \mathrm{~m}(0 / 45 ; 0 /$ 64); Chemal $400 \mathrm{~m}(29 / 58)$; Chemal Creek, 3 km upstream $450 \mathrm{~m}(34 / 239)$; Chemal, $5 \mathrm{~km}$ to the $S E 500 \mathrm{~m}$ (Makarov \& al. 3.VI.1972); Chiri Creek, $0.5 \mathrm{~km} \mathrm{up-}$ stream $450 \mathrm{~m}(17 / 86 ; 17 / 89)$; Chulcha River, in middle course $1100 \mathrm{~m}$ (9/102); Elekmonar Creek, $25 \mathrm{~km}$ upstream $1100 \mathrm{~m}(26 / 73)$; Kamga Creek, 3 km upstream $460 \mathrm{~m}(0 / 1659)$; Kamga Creek, 4 km upstream $470 \mathrm{~m}$ 


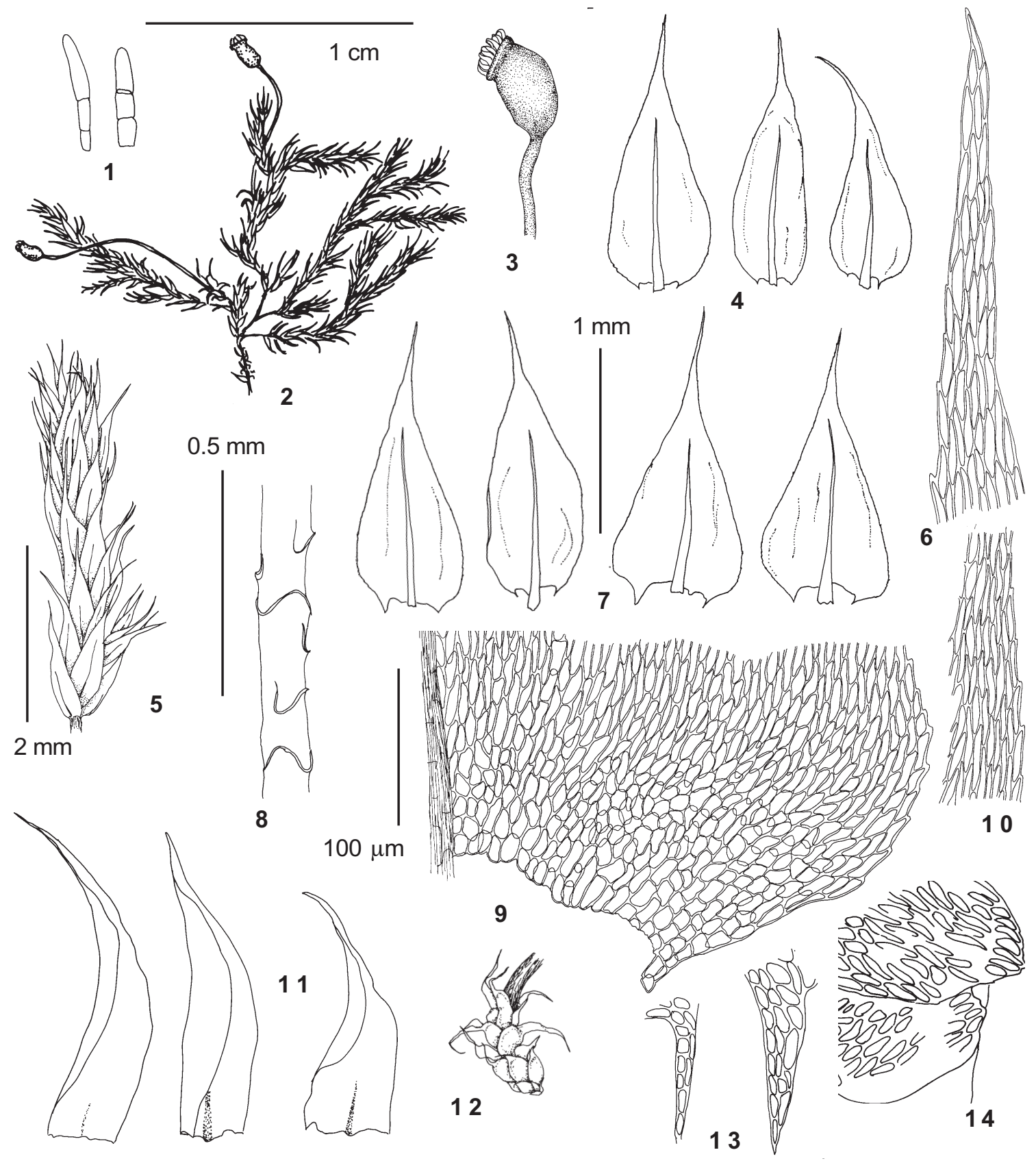

Fig. 31. Brachythecium plumosum (Hedw.) B. S. G. (from Ignatov 15/93): 1 - axillary hairs; 2 - habit; 3 capsule; 4 - branch leaves; 5 - upper part of stem; 6 - upper laminal cells of stem leaf; 7 - stem leaves; 8 - stem leaf insertions; 9 - basal cells of stem leaf; 10 - median laminal cells of stem leaf; 11 - perichaetial leaves; 12 perichaetium; 13 - leaf decurrencies; 14 - branch initial with pseudoparaphyllia. Scale bars: $1 \mathrm{~cm}$ for $2 ; 2 \mathrm{~mm}$ for 3 , 5,$12 ; 1 \mathrm{~mm}$ for $4,7,11 ; 0.5 \mathrm{~mm}$ for $8 ; 100 \mu \mathrm{m}$ for $1,6,9-10,13-14$.

(0/1642); Karagai $440 \mathrm{~m}(0 / 446), 450 \mathrm{~m}(0 / 2048)$; Kobukhta $550 \mathrm{~m}(0 / 239)$; Kobukhtushka $440 \mathrm{~m}(0 /$ 1641), $450 \mathrm{~m}$ (Zolotukhina 28.III.1988); Kokkul Lake $2300 \mathrm{~m}(33 / 31) ;$ Kokorya Creek $2400 \mathrm{~m}(32 / 48)$; Kukol $1750 \mathrm{~m}(0 / 447)$; Kumzir $450 \mathrm{~m}(20 / 21)$; UstSema $500 \mathrm{~m}(24 / 100) ;$ Yailyu $440 \mathrm{~m}$ (Zolotukhin 6.X.1988), $445 \mathrm{~m}$ (Zolotukhina 14.VII.1988), $450 \mathrm{~m}$
(Zolotukhina 14.VII.1988; $0 / 1639 ; 1 / 16 ; 1 / 65 ; 1 /$ 84), $480 \mathrm{~m}(0 / 1660)$.

Brachythecium plumosum (Hedw.) B.S.G., Bryol. Eur. 6: 8 (fasc. 52-54 Monogr. 4). 1853.

Fig. 31 
Hypnum plumosum Hedw., Sp. Musc. Frond. 257. 1801.

Plants medium-sized, yellow-green to goldenbrownish and bronze. Stem up to $3 \mathrm{~cm}$ long, rather densely foliate, irregularly branched, branches subjulaceous, to $5 \mathrm{~mm}$ long. Pseudoparaphyllia obtusely-triangular. Axillary hairs 3-4-celled, to 55-80 x 9-11 $\mu \mathrm{m}$, apical cell 30-45 $\mu \mathrm{m}$ long. Stem leaves 1.62.0. x 0.7-0.9(1.0) mm, ovate-lanceolate, \pm gradually to abruptly acuminate, widest at $1 / 3-1 / 6$ (in wider leaves) $-1 / 10$ (in narrower) of leaf length; concave, not or indistinctly plicate; shortly to moderately decurrent; costa reaching $0.35-0.65$ of leaf length, 35-60 $\mu \mathrm{m}$ wide at base, shortly above becoming much narrower; margin weakly serrulate throughout. Median laminal cells 30-65(75) x 7-9 (3.5-6.5/2.0-3.0) $\mu \mathrm{m}$; cell walls thick and porose, towards base cells short, but only slightly wider and rich in chloroplasts, so that cells across the whole leaf base form an opaque area; sometimes few cells in leaf corners below opaque zone are larger and transparent. Branch leaves similar in shape, but narrower; costa not ending in spine. Autoicous, almost always with sporophytes. Perichaetia and perigonia on stem. Perichaetial leaves \pm gradually acuminate, reflexed, with weak costa. Seta to $10 \mathrm{~mm}$, mammillose. Capsule 1.2-1.5 mm long, inclined. Operculum short-conic. Spores 16-19 $\mu \mathrm{m}$.

In most cases Brachythecium plumosum can be identified under stereomicroscope by its rich yellow-bronze color and characteristic leaves. The latter are \pm rigid, strongly concave, and never plicate (though numerous plicae form in microscope slides). Microscopic characters include (1) thick walls of laminal cells; (2) relatively short cells almost to the leaf base; (3) opaque basal cells. Worldwide this species is very polymorophic, but within each region the variability is relatively small. In Altai it is medium-sized with straight (rarely slightly falcate), ovate-lanceolate leaves (rarely lanceolate).

Distribution: Nearly cosmopolitan species, known from the subarctic to middle and high elevations of tropical mountains, but avoiding regions where rocky substrates are very rare. In Altai it grows exclusively on wet rocks, usually close to creeks or streams, at all the altitudes.

Specimens examined: Bayas Creek, in middle course $850 \mathrm{~m}(16 / 29)$; Bolshoi Shaltan Creek $530 \mathrm{~m}$ (0/1653a), $540 \mathrm{~m}$ (Zolotukhin 7.VI.1989), $550 \mathrm{~m}(0 / 1679)$; Kairu Creek, 8 km upstream $1000 \mathrm{~m}(15 / 85 ; 15 / 93)$; Kamga Creek, $10 \mathrm{~km}$ upstream $500 \mathrm{~m}$ (0/103); Kamga Creek, upper course $830 \mathrm{~m}$ (Zolotukhin 7.VI.1991); Kayakkatuyarykskij Creek $1800 \mathrm{~m}(8 / 29), 1920 \mathrm{~m}$ (3/142a; 3/ 145; 3/213), $2050 \mathrm{~m}$ (3/60), $2100 \mathrm{~m}$ (7/134); Kishte $440 \mathrm{~m}$ (Zolotukhin 11.VII.1988); Kobukhtushka $440 \mathrm{~m}$
(Zolotukhina 28.III.1988); Ok-Porok Creek, $1.5 \mathrm{~km} \mathrm{up-}$ stream $470 \mathrm{~m}(2 / 12 ; 2 / 13 ; 2 / 41)$; Ust-Sema $350 \mathrm{~m}$ (24/119).

Sect. Pseudocirriphyllum Igantov sect. nov.

Folia concava pilefiera. Preudoparaphyllia obtusa. Cellulae alares subquadratae opaquae. Seta scabra. Operculum conicum.

Type: B. cirrosum (Schwaegr.) Schimp.

Brachythecium cirrosum was placed in Cirriphyllum by most of recent authors (cf.Table 1, p. 91). The discussion on its generic position is under the latter genus. Robinson $(1962,1987)$ considered this species in Brachythecium and placed in the sect. Brachythecium. However, $B$. cirrosum has very concave pilifeous leaves and small alar cells that are somewhat odd for this section. Thus, a new section is proposed.

Brachythecium cirrosum (Schwaegr.) Schimp., Syn.: 696. 1860.

Fig. 32

Hypnum cirrosum Schwaegr. in Schult., Reise Glockner: 365.1804.- Cirriphyllum cirrosum (Schwaegr.) Grout, Bull. Torr. Bot. Cl. 25: 223. 1898.

Plants green to pale-yellow or sometimes richgolden. Stem irregularly or sometimes regularly branched, branches with julaceous foliage, to $10 \mathrm{~mm}$ long. Pseudoparaphyllia triangular or truncate-triangular. Axillary hairs 2-3-celled, to $60 \times 6-8 \mu \mathrm{m}$, apical cell $50 \mu \mathrm{m}$ long. Stem leaves to $2.5 \times 0.9 \mathrm{~mm}$, ovate, very abruptly contracted to filiform acumen, most wide at $1 / 3-1 / 2$ of leaf length; strongly concave and rarely indistinctly plicate (though numerous plicae form in microscope slides); at base shortly decurrent; costa reaching (0.1)0.3-0.6 of leaf length, $30-40 \mu \mathrm{m}$ wide at base; margin serrulate to subentire. Laminal cells 30-70(100) x 6-7(3.5-4.5/ $2-2.5) \mu \mathrm{m}$; towards the base cells wider and shorter in several rows; in leaf corner group of subquadrate cells \pm well delimited, reaching $1 / 4$ of distance to costa. Branch leaves similar in shape; costa not ending in spine. Dioicous. Gametangia and sporophyte not seen from Altai (rare worldwide). [Seta mammillose; operculum conic. Peristome complete].

Brachythecium cirrosum is easy to recognize with the naked eye by its (1) julaceous shoots; (2) usually pale-golden color of the plants; (3) long piliferous acumen of both stem and branch leaves. Cirriphyllum piliferum is similar to B. cirrosum in having piliferous stem leaves but differs in the green or whitish green (vs. pale-yellow) color of plants, often weakly piliferous branch leaves (vs. always piliferous), 


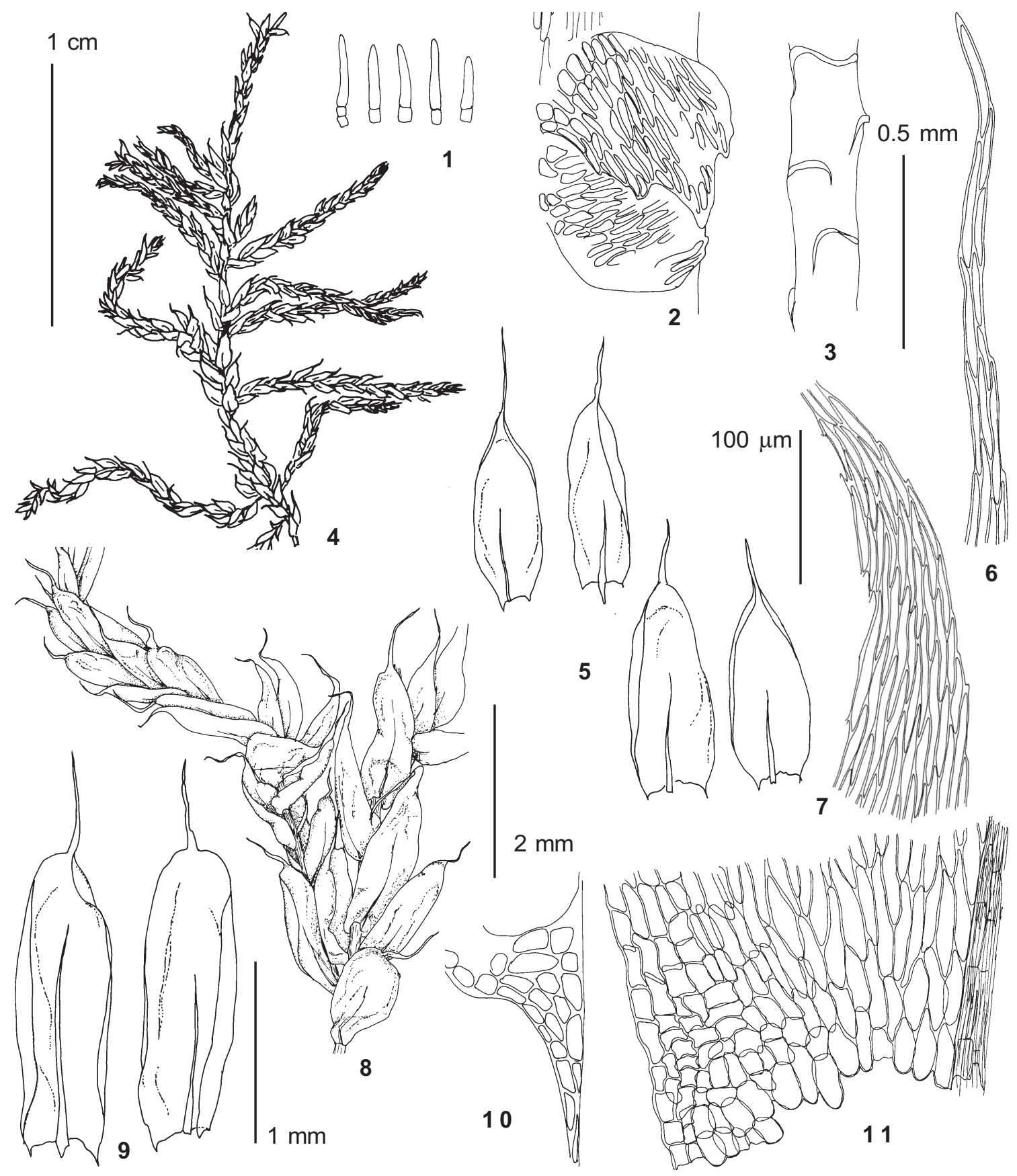

Fig. 32. Cirriphyllum cirrosum (Schwaegr.) Grout. (from Ignatov $21 / 7$ ): 1 - axillary hairs; 2 - branch initial with pseudoparaphyllia; 3 - stem leaf insertions; 4 - habit; 5 - branch leaves; 6 - upper laminal cells of stem leaf; 7 - median laminal cells of stem leaf; 8 - middle part of stem with proximal branch; 9 - stem leaves; 10 - leaf decurrency; 11 - basal cells of stem leaf. Scale bars: $1 \mathrm{~cm}$ for $4 ; 2 \mathrm{~mm}$ for $8 ; 1 \mathrm{~mm}$ for 5,$9 ; 0.5 \mathrm{~mm}$ for 3; $100 \mu \mathrm{m}$ for 1-2, 6-7, 10-11.

enlarged thin-walled alar cells (vs. small, \pm thick-walled), and by usually growing in wet shaded habitats, on soil rich in humus, while Brachythecium cirrosum prefers rocky habitats and grows on mineral soil only at higher elevations. Rarely B. cirrosum has deep-green and regularly pinnate plants (Fig. 32).

In xeric areas of Altai on \pm wet and exposed cliffs $B$. cirrosum sometimes develops very slender phenotypes, with leaves less than $0.5 \mathrm{~mm}$ wide. However, in extensive collections from such places some 
shoots with larger leaves were found, establishing a transition to the average-sized phenotype.

Distribution: Brachythecium cirrosum is widely distributed in the Arctic and in the mountain regions of the Holarctic. It is totally absent in lowland regions of Russia, but in mountains (including Altai) grows at all the elevations - in high mountains on soil and rocks in tundra, and within the forest and forest-steppe zones on wet cliffs (in the upper part of the forest zone sometimes on soil in more calcareous areas).

Specimens examined: Ak-Alakha River $2000 \mathrm{~m}$ (Kalinina \& al. 534 LE!); Bayas Creek, in middle course $800 \mathrm{~m}$ (16/23); Bele $550 \mathrm{~m}(0 / 57 ; 0 / 59)$; Bogoyash Creek, upper course $2450 \mathrm{~m}(36 / 129)$; Bolshoi Shaltan Creek $530 \mathrm{~m}$ (0/1140), $560 \mathrm{~m}$ (Zolotukhin 7.VI.1989); Bolshoye Istyube Creek 470 m (Zolotukhin 5.VII.1988); Chainary Creek, upper course $1800 \mathrm{~m}(34 / 195)$; Chemal $450 \mathrm{~m}$ (29/77); Chiri $450 \mathrm{~m}$ (17/31); Chiri Creek, 0.5 km upstream $450 \mathrm{~m}$ (17/15); Chulcha River, in middle course $1000 \mathrm{~m}$ (9/4); Derbogach $450 \mathrm{~m}(0 / 19)$; Elekmonar Creek, 15 km upstream $850 \mathrm{~m}$ (26/62); Elekmonar Creek, $5 \mathrm{~km}$ upstream $700 \mathrm{~m}$ (26/18); Kairu Creek, 8 km upstream $1000 \mathrm{~m}$ (15 / 103; $15 / 13)$; Kamga Creek, 10 km upstream $530 \mathrm{~m}(0 /$ 109), $560 \mathrm{~m}$ (0/1142; 0/1144); Kamga Creek, 14 km upstream $600 \mathrm{~m}(0 / 100)$; Kayakkatuyarykskij Creek $1900 \mathrm{~m}$ (8/280); Kishte $440 \mathrm{~m}$ (Zolotukhin 11.VII.1988); Kobukhta $600 \mathrm{~m}$ (0/234); Kukol $1820 \mathrm{~m}(0 / 642), 1850 \mathrm{~m}(0 / 1141)$, 1900 m (0/1143); Kumzir 450 m (20/6); Malyi Yaloman Creek, 7 km upstream 1000 m (25/41); Nizhnij Kulash 1600 m (Zolotukhin 2.VII.1989); Tabozhok Peak $2350 \mathrm{~m}$ $(31 / 53 ; 31 / 54)$; Tokpak Creek, in middle course $1950 \mathrm{~m}$ (36/282); Ulagan $1220 \mathrm{~m}(36 / 192)$; Ust-Sema $340 \mathrm{~m}$ (24/44); Yurga $440 \mathrm{~m}(21 / 39), 450 \mathrm{~m}(21 / 7)$.

\section{Cirriphyllum Grout}

This genus was described by Grout (1898) for 5 species, C. piliferum, C. cirrosum, C. tomassinii (Boul.) Grout, C. illecebrum (Hedw.) Grout and C. brandegei (Aust.) Grout. About 10 species were added to this genus later. Robinson (1962) revised the North American species, did not accepted $C$. brandegei as a good species, segregated $C$. illecebrum into the new genus Bryoandersonia, lectotypified the genus with Cirriphyllum piliferum, placed both $C$. piliferum and C. cirrosum in Brachythecium, and therefore put Cirriphyllum into the synonymy of Brachythecium. However, later Robinson (1987) changed his mind and accepted Cirriphyllum as a separategenus for C. piliferum, leaving C. cirrosum in Brachythecium.

Karttunen (1990) revised the European species of Cirriphyllum and transferred some of them to Eurhynchium, leaving three species with longly piliferous leaves, scabrous seta, and rostrate to high conic operculum in Cirriphyllum: C. cirrosum, C. piliferum and C. tomassinii.

The main reason for the segregation of Cirriphyllum, Karttunen (1990) found in characteristic piliferous leaves. However, I cannot confirm that this character is unique in Brachytheciaceae. Brachythecium papuense Ignatov, $B$. lamprocarpum (Dozy et Molk.) Jaeg., B. longicuspidatum (Mitt.) Jaeg., B. helminthocladum (Broth.) Par., B. conostomoides (Tayl.) Jaeg. also have leaves that are suddenly contracted to a narrow acumen. These species have smooth seta, and other features standing them not very close to Cirriphyllum. To my mind, the reason for the segregation of Cirriphyllum can be only that its species have rostrate operculum (a character of Eurhynchium-Rhynchosteguim group of genera) and piliferous leaves (which occur in the Brachytheciaceae besides Cirriphyllum only in some species of Brachythecium). Brachythecium (Cirriphyllum) cirrosum has been reported as having conic operculum ( $\mathrm{Mo}^{-}$ lendo, 1875, cited by Limpricht, 1895), so it should be placed outside Cirriphyllum.

Cirriphyllum piliferum (Hedw.) Grout, Bull. Torrey Bot. Club 25: 225. 1898. Fig. 33 Hypnum piliferum Hedw., Sp. Musc. Frond. 275. 1801.

Plants robust, green to whitish-green. Stem prostrate, regularly remotely branched, branches subjulaceous, to $17 \mathrm{~mm}$ long. Pseudoparaphyllia truncate-triangular to broadly rounded at apex. Axillary hairs (3)4-5-celled, to 60-70 x $9 \mu \mathrm{m}$, apical cell to $40 \mu \mathrm{m}$ long (1-2 upper cells longer, 2-3 basal cells shorter; upper basal cell shorter and darker in color than cells above and below). Stem leaves erect-appressed, to $2.4 \times 1.4 \mathrm{~mm}$, ovate, very abruptly contracted to filiform acumen, widest at $1 / 5$ $1 / 7$ of leaf length; strongly concave, indistinctly plicate (though numerous plicae form on microscope slides); at base longly and broadly decurrent; costa reaching $0.25-0.5$ of leaf length, $80 \mu \mathrm{m}$ wide at base; margin serrate. serrulate or sometimes subentire. Median laminal cells 60-100 x 7-9 (6-7.5/1.01.5) $\mu \mathrm{m}$; towards base cells wider and shorter in several rows; in leaf corner cells wider, forming extensive alar group, \pm well delimited and reaching $1 / 2-1 / 3$ of distance to costa. Branch leaves lanceolate, abruptly tapered into short, often twisted acumen; costa not ending in spine. Perichaetia on stem. Perigonia not seen in Altaian collections. [Dioicous. Seta mammillose. Operculum rostrate]. 

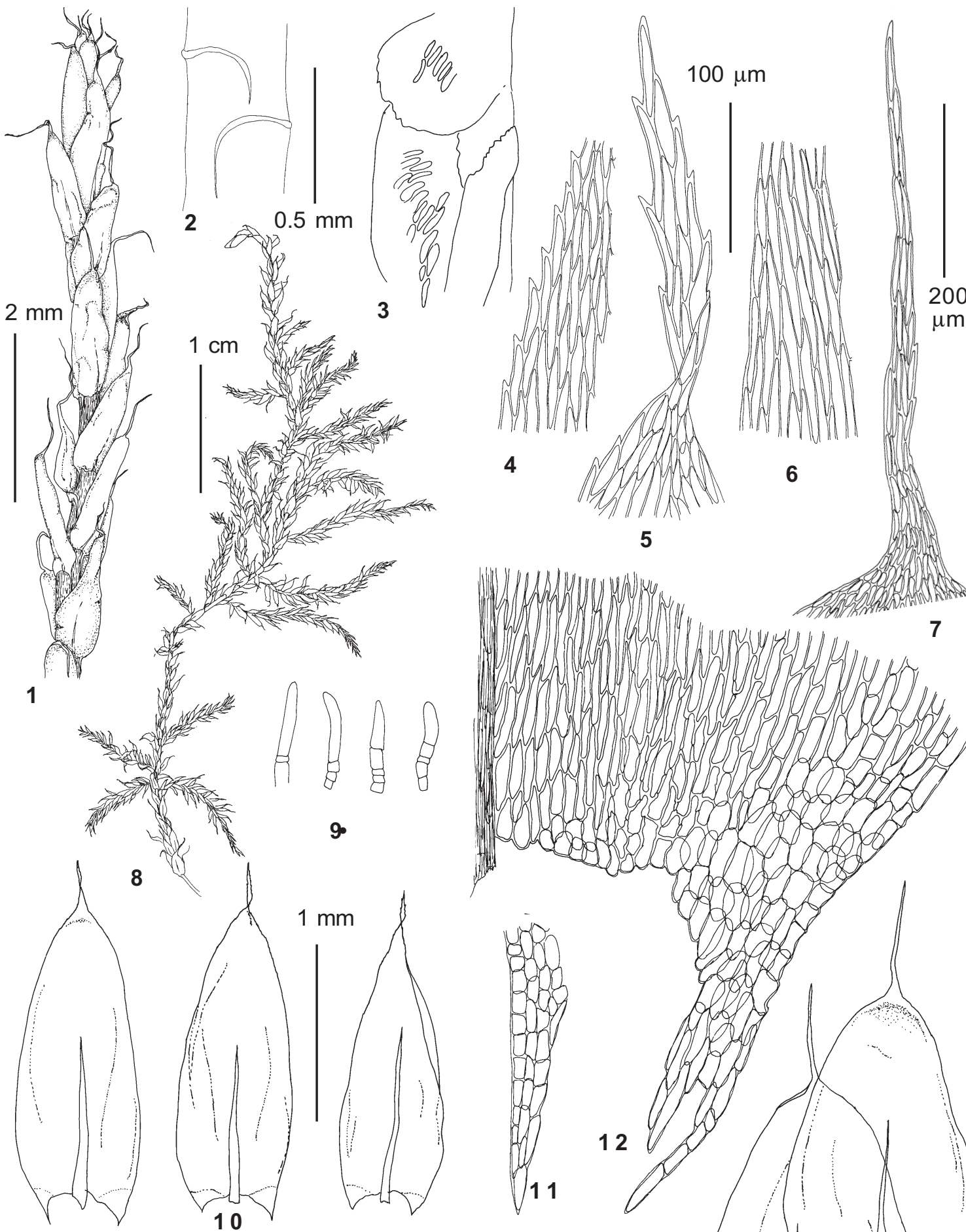

6

5

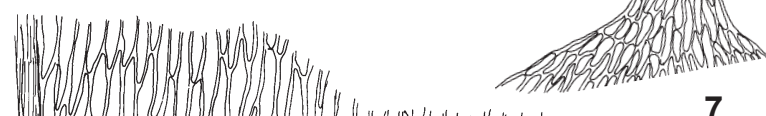

7

Fig.33.Cirriphyllum piliferum (Hedw.) Grout (from Ignatov 34/133): 1 - upper part of stem; 2 - stem leaf insertions; 3 - branch initial with pseudoparaphyllia; 4 - median laminal cells of branch leaf; 5 - upper laminal cells of branch leaf; 6 - median laminal cells of stem leaf; 7 - upper laminal cells of stem leaf; 8 - habit; 9 - axillary hairs; 10 - branch leaves; 11 leaf decurrency; 12 - basal cells of stem leaf; 13 - stem leaves. Scale bars: 1 $\mathrm{cm}$ for $8 ; 2 \mathrm{~mm}$ for $1 ; 1 \mathrm{~mm}$ for 10,$13 ; 0.5 \mathrm{~mm}$ for $2 ; 200 \mu \mathrm{m}$ for $3,7,12 ; 100$ $\mu \mathrm{m}$ for $4-6,9,11$.

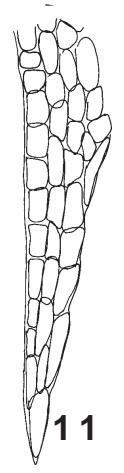

12

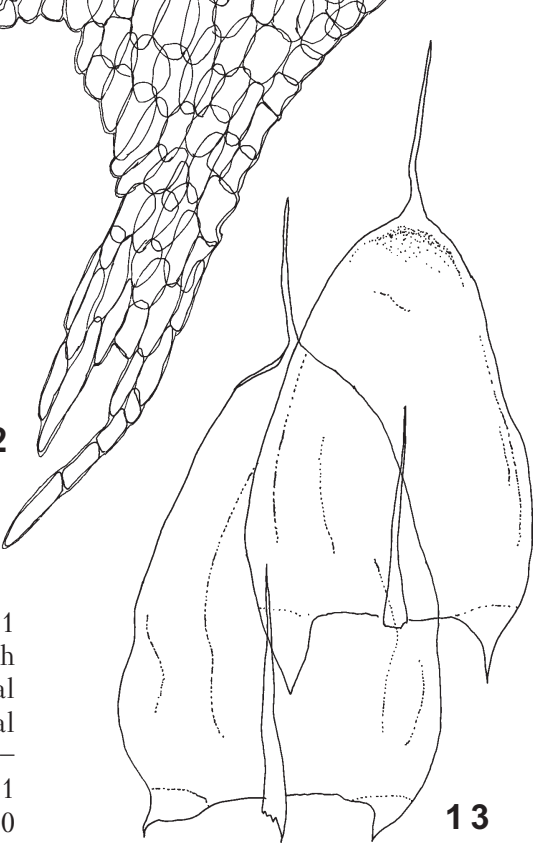


Distribution: Widespread species in boreal, hemiboreal and northern temperate forests throughout Eurasia, Northern Africa, and Eastern North America. In Altai it occurs in the lower forest zone (up to $1500 \mathrm{~m}$ ), growing on soil rich in humus in mixed conifer forests (usually dominated by Abies and Pinus sibirica), more rarely in tall-herb meadows.

Specimens examined: Bayas Creek, in middle course $850 \mathrm{~m}(16 / 11)$; Bele $550 \mathrm{~m}(0 / 55)$; Bolshoye Istyube Creek 470 m (Zolotukhin 5.VII.1988; 18/107a; 18/33); Chemal Creek, 3 km upstream $450 \mathrm{~m}$ (34/62); Chulcha River, in middle course 1000 m (9/112); Edikhta Creek $1100 \mathrm{~m}$ (34/133); Elekmonar Creek, $25 \mathrm{~km}$ upstream 900 m (26/74); Kaitanak Creek 1500 m (Krylov \& Reczan 10.VII.1968 LE!); Kia (Schischkin 14.IX.1931 LE!); Maima $280 \mathrm{~m}(35 / 30)$.

\section{Bryhnia Kaurin}

The genus is characterized by: (1) numerous sympodial branches and sometimes also short branches with small spreading leaves; (2) relatively broad stem leaves, which in many species are very polymorphic; (3) laminal cells that are prorate on the adaxial surface (though in some plants perfectly smooth); (4) dioicous plants, with rare sporophyte production; (5) mammillose seta; (6) high-conic to subrostrate operculum.

The most particular character of this genus is the distinctly prorate cells of the upper part of the dorsal branch leaves. This character is constantly used in keys, though a significant portion of the collections have perfectly smooth laminal cells. In many collections prorate cells are distinct only in small divergent leaves developing on short branches, whereas larger branches bear leaves similar to stem leaves.

Bryhnia novae-angliae (Sull. et Lesq.) Grout, Bull. Torr. Bot. Club 25: 229. 1898. - Hypnum novae-angliae Sull. et Lesq., Musc. Bor. Am. 338. 1856.

Figs. 34, 35

Plants robust to medium-sized, yellow-green to yellow-brownish or pale-yellow. Stem prostrate, irregularly branched with numerous subjulaceous sympodial branches, rarely short branches (to $3 \mathrm{~mm}$ long) with remote, spreading, subcomplanate leaves present. Pseudoparaphyllia triangular. Axillary hairs 2-3celled, to $50 \times 8 \mu \mathrm{m}$, apical cell to $30 \mu \mathrm{m}$ long. Leaves of shoot ends always ovate to broadly ovate, widest at ca. $1 / 5$ of leaf length, acute to acuminate, 1.3-1.6 x 0.8-1.1 mm, moderately concave, their upper laminal cells $30-40 \mu \mathrm{m}$ long, median laminal cells $30-60 \mathrm{x}$ 8-11 (6-9/1.5-2.5) $\mu \mathrm{m}$; older leaves of middle part of many shoots much shorter, to suborbicular and very concave, broadly acute, $1.0-1.3 \times 1.0 \mathrm{~mm}$, widest at $1 / 2-1 / 3$ of the leaf length, their upper laminal cells $15-20 \mu \mathrm{m}$ long, median laminal cells $30-40 \times 8$ $11(6.5-9 / 2-3) \mu \mathrm{m}$; in most proximal part of shoots leaves usually acute, moderately concave, broadly ovate, similar to upper leaves, but somewhat smaller. Sometimes concave leaves absent and all leaves of shoot are acute or acuminate; sometimes acute leaves restricted to shoot end and all leaves further down concave. Leaves at base longly and broadly decurrent. Costa reaching (0.4)0.6-0.7 of leaf length, to $55 \mu \mathrm{m}$ wide at base, ending in stout tooth in acute and acuminate leaves, sometimes with several teeth on adaxial costa near its end; in suborbicular, more concave leaves costa thinner, not ending in spine. Margin serrate to subentire; cells of leaf corner enlarged and inflated, forming distinctly delimited submarginal group of subquadrate cells $(15-17 \mu \mathrm{m}$ wide), reaching $1 / 2$ of distance to costa; basal marginal cells long-rectangular in 1-2 rows. Leaves of small branches ovate-lanceolate, less than $0.5 \mathrm{~mm}$ wide, costa ending in spine, laminal cells projecting on abaxial surface. Dioicous. Perichaetia on stem, with numerous paraphyses, perichaetial leaves of unfertilized perichaetia widely reflexed. Perigonia and sporophytes not found in Altaian specimens. [Seta rough. Peristome complete. Cilia nodose. Operculum with long, weakly delimited beak].

Plants from South Siberia are referred to the widespread $B$. novae-angliae, though their average habit is fairy distinct from most collections from Eastern North America. However the differences concern mainly the relative frequencies of leaves of different types. Short, concave, suborbicular leaves are absent in most (but not all!) American collections, and are more rare also in collections from Japan, Russian Far East and China. In collections from Altai and other places of South Siberia, "Myuroclada-like" leaves (cf. Fig. 34-12 \& 3512) are present in all collections, sometimes prevailing, sometimes occurring just in few shoots. Acute, rather rigid and erect leaves are rather common in American and Japanese collections, but rare in Altaian ones. More common in Altaian plants are acuminate, rather soft leaves, much resembling branch leaves of Brachythecium rivulare from shady habitats; laminal cells of them are smooth and elongate. Such leaves not always present in American collections. However these differencies alone do not allow to segregate any taxa, because of the enormous variability of leaves within each region. Size of laminal cells seems 


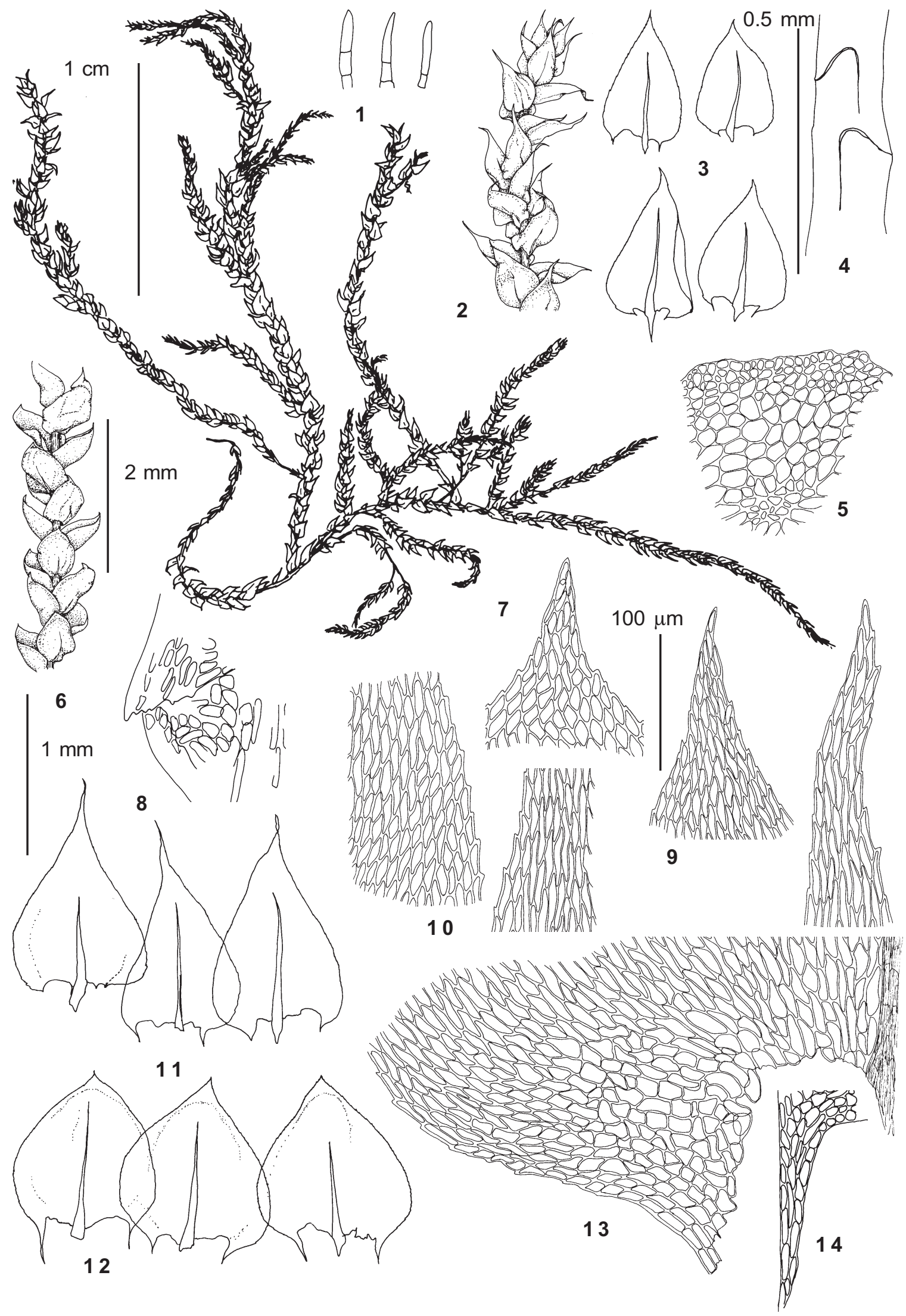




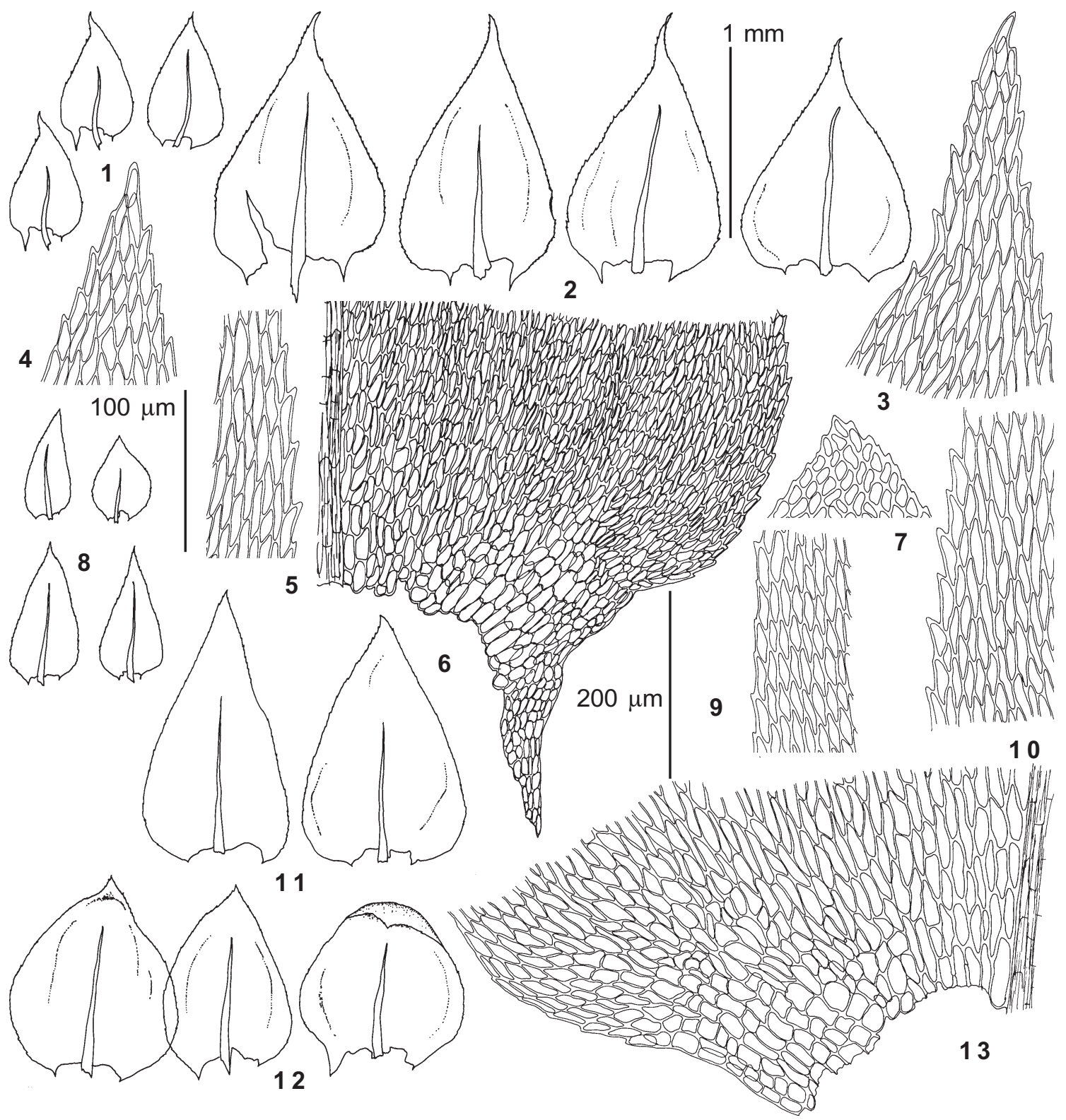

Fig. 35. Bryhnia novae-angliae (Sull. et Lesq.) Grout (1-6, 10 - from Ignatov 31/227; 7-9, 11-13 - from Ignatov $31 /$ 227): 1, 8 - branch leaves; 2, 11 - leaves from upper part of shoot; 3-4, 7 - upper laminal cells, showing variation; 5, 910 - median laminal cells, showing variation; 6, 13 - basal cells of stem leaf; 12 - "Myuroclada-like" leaves of middleproximal part of shoot. Scale bars: $1 \mathrm{~mm}$ for 1-2, 8, 11-12; $200 \mu \mathrm{m}-6 ; 100 \mu \mathrm{m}$ for 3-5, 7, 9-10, 13.

$\leftarrow$ Fig. 34. Bryhnia novae-angliae (Sull. et Lesq.) Grout (from Ignatov 15/10): 1 - axillary hairs; 2 - upper part of stem; 3 - leaves of young sympodial branch; 4 - stem leaf insertions; 5 - stem transverse section; 6 - middle-proximal part of shoot with "Myuroclada-like" leaves; 7 - habit; 8 - branch initial with pseudoparaphyllia; 9 - upper laminal cells of leaves from different parts of shoot; 10 - median laminal cells, showing variation; 11 - leaves from upper part of shoot; 12 - "Myuroclada-like" leaves of middle-proximal part of shoot; 13 - basal cells of stem leaf; 14 - leaf decurrency. Scale bars: $1 \mathrm{~cm}$ for $7 ; 2 \mathrm{~mm}$ for 2, 6; $1 \mathrm{~mm}$ for 3, 11-12; $0.5 \mathrm{~mm}$ for 4; $100 \mu \mathrm{m}$ for 1, 5, 8-10, 13-14.

to correlate with leaf shape, as well as toothed but in some collections the cells are smooth. In or smooth end of costa, so they cannot be used as an independent characters. The character of projecting cell ends of laminal cells is often well-expressed in North American plants, Altai the leaf cells are almost always smooth, but in other regions of South Siberia plants with the same set of other characters have sometimes strongly prorate laminal cells. 
According to the keys of Takaki (1956) and Nocuchi (1991), specimens with the numerous suborbicular leaves and smooth costa bolong to B. hultenii Bartr. or B. brachycladula Card. The latter species was reported from the South Siberia (Bardunov, 1969, 1992; Muldiyarov, 1990). However, available collections of these authors are obviously identical with those that are described above and have at least some acute leaves with the costa that ends in a spine, which disagree with the two latter species. According to Takaki (1956) and Nocuchi (1991), B. novae-angliae does not have "Myuroclada-like" leaves, but since such leaves occur in some collections from Eastern North America and Europe, this statement seems no longer valid.

The other extreme of variation of $B$. novaeangliae (with most leaves acuminate) looks similar to $B$. rivulare. However, the latter is usually larger, has longer laminal cells, a costa that does not ends in tooth, and does not have part of shoots with "Myuroclada-like" leaves.

The rare sporophyte production and primarily vegetative reproduction of $B$. novae-angliae may be an explanation for the quantitative differences in local, isolated populations.

Distribution: Bryhnia novae-angliae is widely distributed in eastern North America and eastern Asia (Japan, Korea, China, Russian Far East and South Siberia). It occurs also in Sweden and Norway, but uncommon there. In Altai B. novae-angli$a e$ occurs only at lower elevations, on alluvial substrates covering fallen logs, trunk bases, and rocks along both big rivers (Katun), creeks (Chemal, Elekmonar, Ok-Porok), and, in the area of Teletzkoye Lake, also along small temporary streams in ravines.

Specimens examined: Aya $300 \mathrm{~m}$ (Tyulina 2.V.1952 LE!); Bele $500 \mathrm{~m}(0 / 51)$; Chemal Creek, $3 \mathrm{~km}$ upstream $450 \mathrm{~m}(34 / 227 ; 34 / 238)$; Elekmonar Creek, 15 km upstream $900 \mathrm{~m}(26 / 67)$; Kamga Bay $440 \mathrm{~m}$ (Zolotukhin 20.X.1988); Maima $280 \mathrm{~m}$ (35/28; 35/57); Ok-Porok Creek, at mouth $450 \mathrm{~m}(0 / 1729)$; Yailyu $450 \mathrm{~m}(1 / 15$; $1 / 34 ; 1 / 53 ; 1 / 74 ; 1 / 89 ; 1 / 90), 480 \mathrm{~m}(0 / 2046)$.

\section{Myuroclada Besch.}

This genus was been established to segregate one species with very peculiar Myurellalike julaceous shoots. Another species placed in this genus, $M$. rotundifolia (Arnell) A. Abramova \& I. Abramov, belongs to Myrinia (Ignatov, in prep.). Brotherus (1925) and Takaki (1955a) placed Myuroclada close to Scleropodium, but Robinson (1962) found it more close to Bryh- nia. I totally agree with the observation of Robinson, that "the rounded concave leaves of Myuroclada are only the extreme which is closely approaching by many specimens of Bryhnia novae-angliae". Myuroclada differs from Bryhnia in uniformly suborbicular leaves, always smooth laminal cells, and a smooth seta.

Myuroclada maximoviczii (Borszcz.) Steere et Schof., Bryologist 59(1): 1. 1956. Fig. 36

Hypnum maximowiczii Borszcz. in Maxim., Prim. Fl. Amur. 467. 1859.

Plants medium-sized, green to yellow-green. Stem irregularly (rarely \pm regularly) branched, branches hardly distinguishable from stem, julaceous, often with attenuate tips. Pseudoparaphyllia orbicular. Axillary hairs 2-4-celled, 30-70 × 6-8 $\mu \mathrm{m}$, apical cell 20-35 $\mu \mathrm{m}$ long. Stem leaves appressed, to $1.2 \times 1.2 \mathrm{~mm}$, orbicular to broadly ovate,often with short tip, widest at $1 / 3$ $1 / 2$ of leaf length; strongly concave, weakly plicate; at base decurrent; costa reaching (0.3) 0.5-0.7 of leaf length, 50-60 $\mu \mathrm{m}$ wide at base; margin serrulate throughout. Median laminal cells 20-30 x 10-12 (8$10 / 2.0-2.5) \mu \mathrm{m}$; towards base cells wider and longer in several rows; along the margin subquadrate cells $(10-12 \mu \mathrm{m})$ reaching leaf base in broad zone. Perigonia on stem; inner perichaetial leaves of unfertilized perichaetia widely reflexed. Only female plants were seen in Altai. [Dioicous. Seta smooth. Operculum with long but not sharply delimited beak].

Distribution: Principally an East Asian species,very common in China, Japan, Korea, Russian Far East, and with scattered localities in South Siberia and Mongolia. Along the Pacific coast it penetrates to the north to ca. $60^{\circ} \mathrm{N}$ in Russia and several localities are known in Alaska. Along the Yenisej River it reaches $68^{\circ} \mathrm{N}$ and it was once collected at about $64^{\circ} \mathrm{N}$ in Archangelsk Province (the only locality of this species in Europe). In Altai Myuroclada is common in the lower forest zone, growing on soil banks, on rocks, sometimes of rotten logs and lower parts of trees, covered by muddy alluvium in flood-valleys. Rarely it occurs in the upper forest and subalpine zones (on landslides).

Specimens examined: Baigazan $450 \mathrm{~m}(0 / 3000)$; Bele $500 \mathrm{~m}(0 / 77), 550 \mathrm{~m}(0 / 1100)$; Chemal $400 \mathrm{~m}(29 / 50)$; Chemal Creek, 3 km upstream $450 \mathrm{~m}$ (34/123); Chichelgan Range $800 \mathrm{~m}$ (Zolotukhin 21.X.1989); Chiri $450 \mathrm{~m}$ (17/38; $17 / 39 \mathrm{a})$; Chulcha River, in middle course $960 \mathrm{~m}$ (9/131), $1000 \mathrm{~m}(9 / 33), 1100 \mathrm{~m}(9 / 100 ; 9 / 123) ;$ Edikhta Creek 1100 m (34/105; 34/115); Elekmonar Creek, 15 km upstream $900 \mathrm{~m}(26 / 63 ; 26 / 68)$; Elekmonar Creek, 5 $\mathrm{km}$ upstream $700 \mathrm{~m}$ (26/4); Gorno-Altaisk (SE edge) $550 \mathrm{~m}$ (23/2); Kairu Creek, 8 km upstream $1000 \mathrm{~m}$ (15/ 92); Kamga Creek, 2 km upstream $445 \mathrm{~m}$ (0/1110); Karagai 440 m (0/652), 450 m (Zolotukhin 11.VIII.1988); Kayakkatuyarykskij Creek 2000 m (8/157); Kobukhta $540 \mathrm{~m}(0 / 1099)$; Kumzir $450 \mathrm{~m}(20 / 14 \mathrm{a})$; Maima $280 \mathrm{~m}$ 


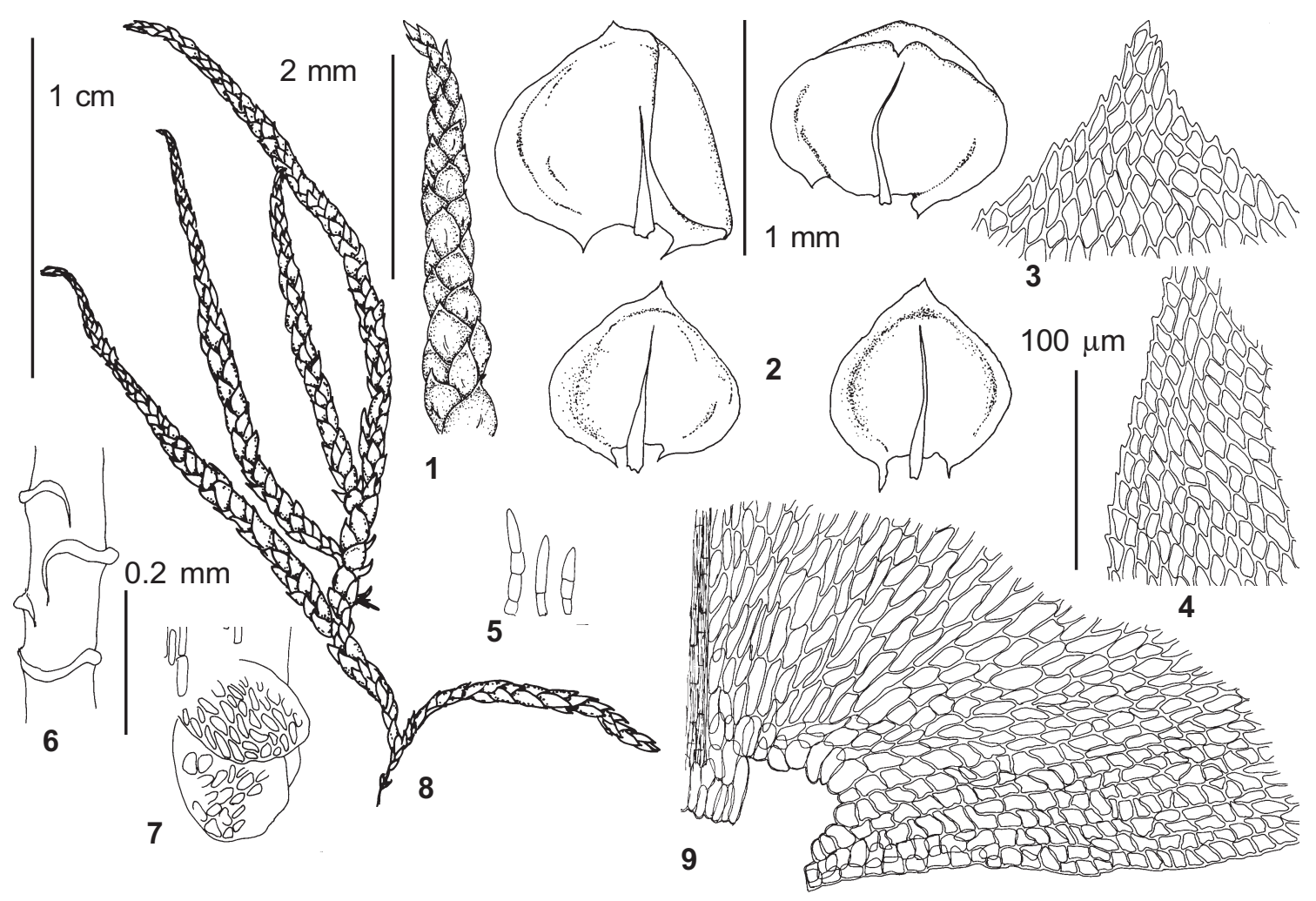

Fig. 36. Myuroclada maximowiczi (Borszcz.) Steere et Schof. (from Ignatov 0/77): 1 - upper part of stem; 2 leaves; 3 - upper laminal cells of stem leaf; 4 - median laminal cells of stem leaf; 5 - axillary hairs; 6 - stem leaf insertions; 7 - branch initial with pseudoparaphyllia; 8 - habit; 9 - basal cells of stem leaf. Scale bars: $1 \mathrm{~cm}$ for 8 ; $2 \mathrm{~mm}$ for $1 ; 1 \mathrm{~mm}$ for $2 ; 0.2 \mathrm{~mm}$ for $6 ; 100 \mu \mathrm{m}$ for $3-4,7,9$.

(35/27); Saratki Cape $450 \mathrm{~m}$ (Zolotukhin 14.X.1987); Yailyu $440 \mathrm{~m}(0 / 1111), 450 \mathrm{~m}(1 / 39), 460 \mathrm{~m}(0 / 1098)$.

Eurhynchium B. S. G.

This genus differs from Brachythecium by a rostrate operculum, a stronger costa that usually ends in a stout tooth, and usually \pm ovate or elliptic,acute to shortly acuminate,non-plicate leaves of somewhat rigid texture.

Species with a rostrate operculum were classifyed by Bruch \& al. (1851-55) into two genera, Rhynchostegium and Eurhynchium. It is not very easy to find a crucial character for the separation of all species of these two genera and recently some authors suggested to combine them under Eurhynchium (Koponen, 1987) or Rhycnhostegium (McFarland, 1994). The former is incorrect, because the genus Rhynchostegium was described earlier than $E u_{\text {- }}$ rhynchium. To my mind, this lumping is unnecessary, because most species of both these genera are some natural segregates, represent obviously natural segregates.

\section{Key tO THE ALtaian SPECIES OF EURHYNCHIUM}

1. Plants robust; stem leaves wider than $1 \mathrm{~mm}$, shortly acute ....... E. angustirete (p. 148)

1. Plants medium-sized to small; stem leaves 0.5$0.8 \mathrm{~mm}$ wide, longly acute to acuminate . . . . 2

2. Branch leaves obtuse ................. ............. E. pulchellum (p. 144)

2. Branch leaves acute ............ 3

3. Branches \pm complante; branch leaves ovate to elliptic,shortly acute .... E. hians (p.144)

3. Branches subjulaceous; branch leaves ovatelanceolate to lanceolate, longly acute to acuminate .............. E. altaicum (p. 141)

Eurhynchium altaicum Ignatov sp. n. Figs. 37,38 Planta mediocris. Caulis prostratus, laxe ramosus. Folia caulina sparsa, patentia vel squarrosa, rigida, non-plicata, anguste-decurrentia, margine omnino serrulata. Costa crassa, evanescenta ad 0.9 longitidinis laminae, spinescenti-terminata. Folia ramulina caulinibus similia. Autoica. Seta mammillosissima. 


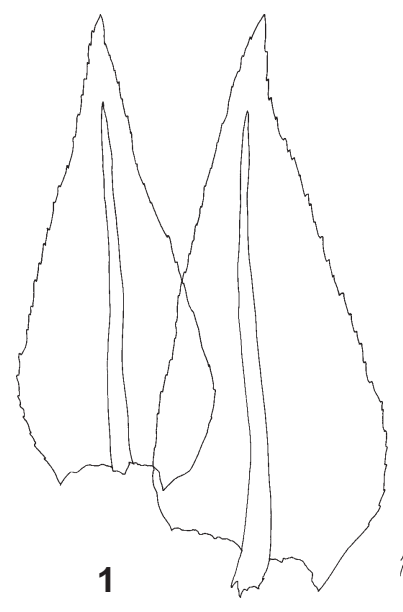

$100 \mu \mathrm{m}$

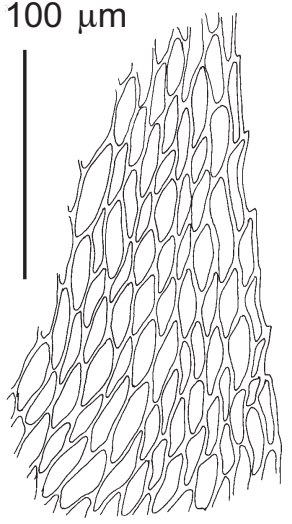

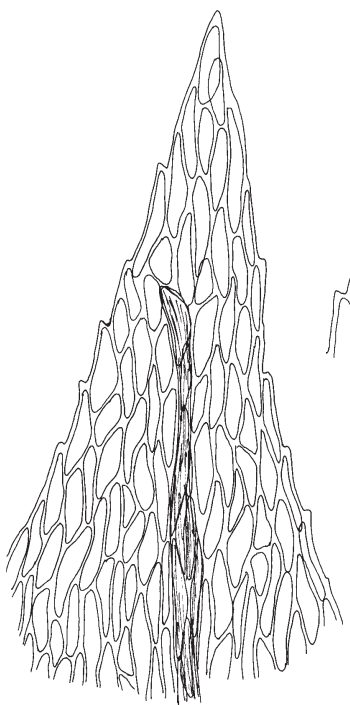

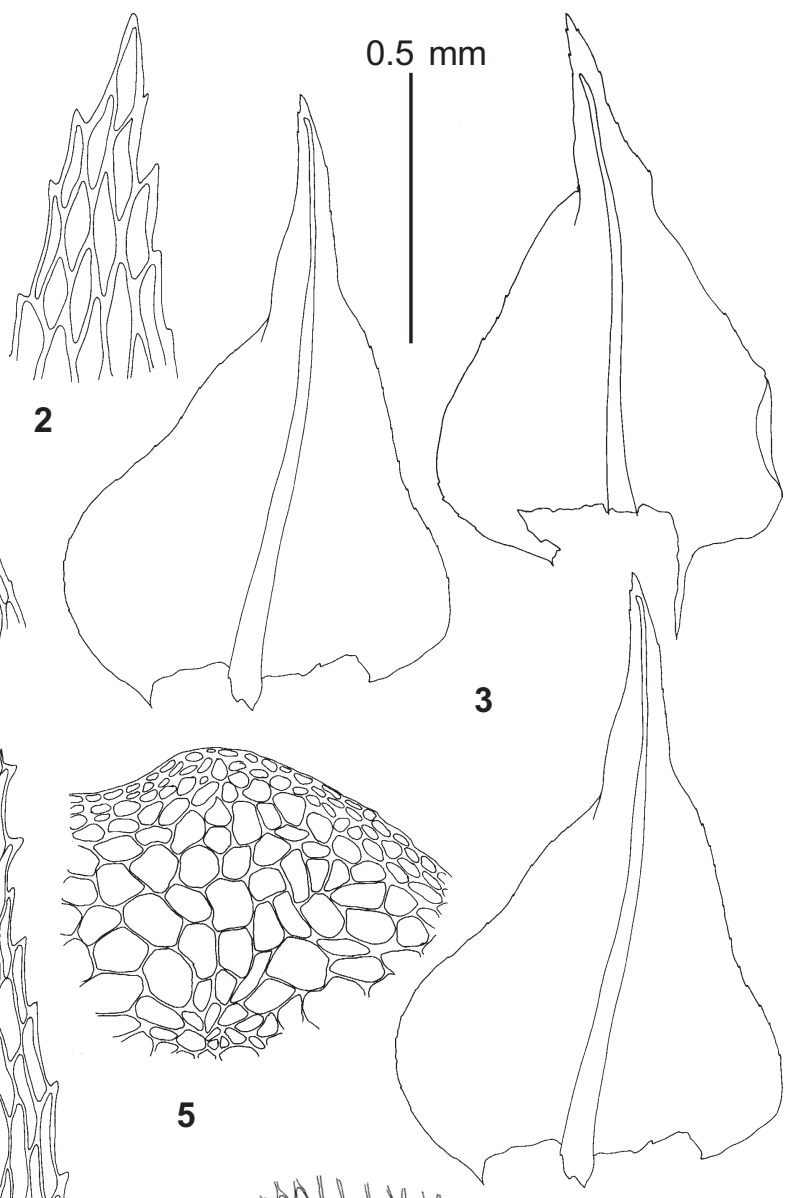

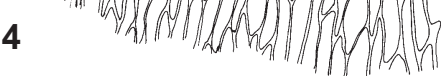
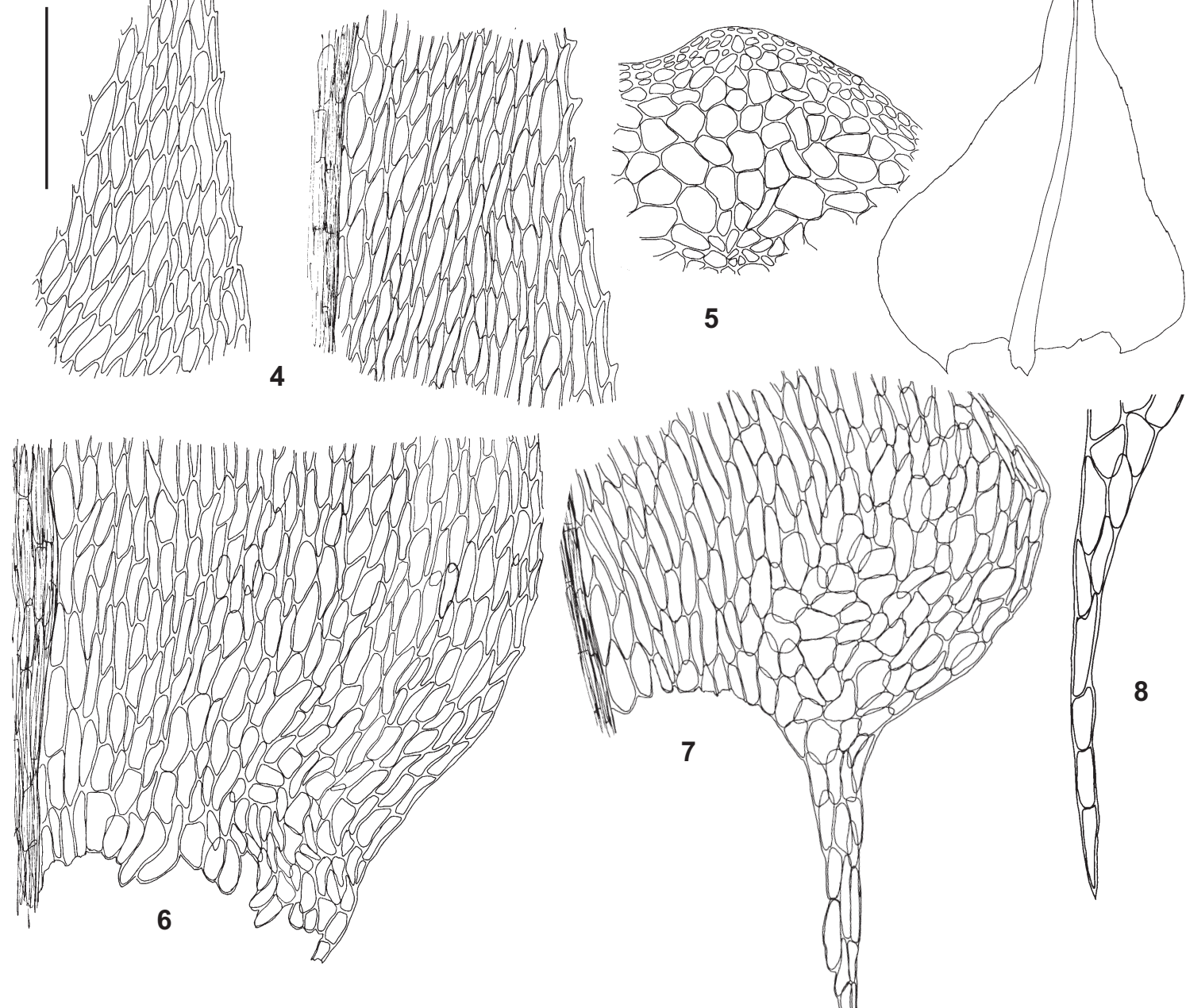

Fig. 37. Eurhynchium altaicum Ignatov sp. n. (from holotype: Keller, 16.VI.1910, H-BR): 1 - branch leaves; 2 upper laminal cells; 3 - stem leaves; 4 - median laminal cells; 5 - stem transverse section; 6-7 - basal cells of stem leaf; 8 - leaf decurrency. Scale bars: $0.5 \mathrm{~mm}$ for 1, 3; $100 \mu \mathrm{m}$ for 2, 4-8. 


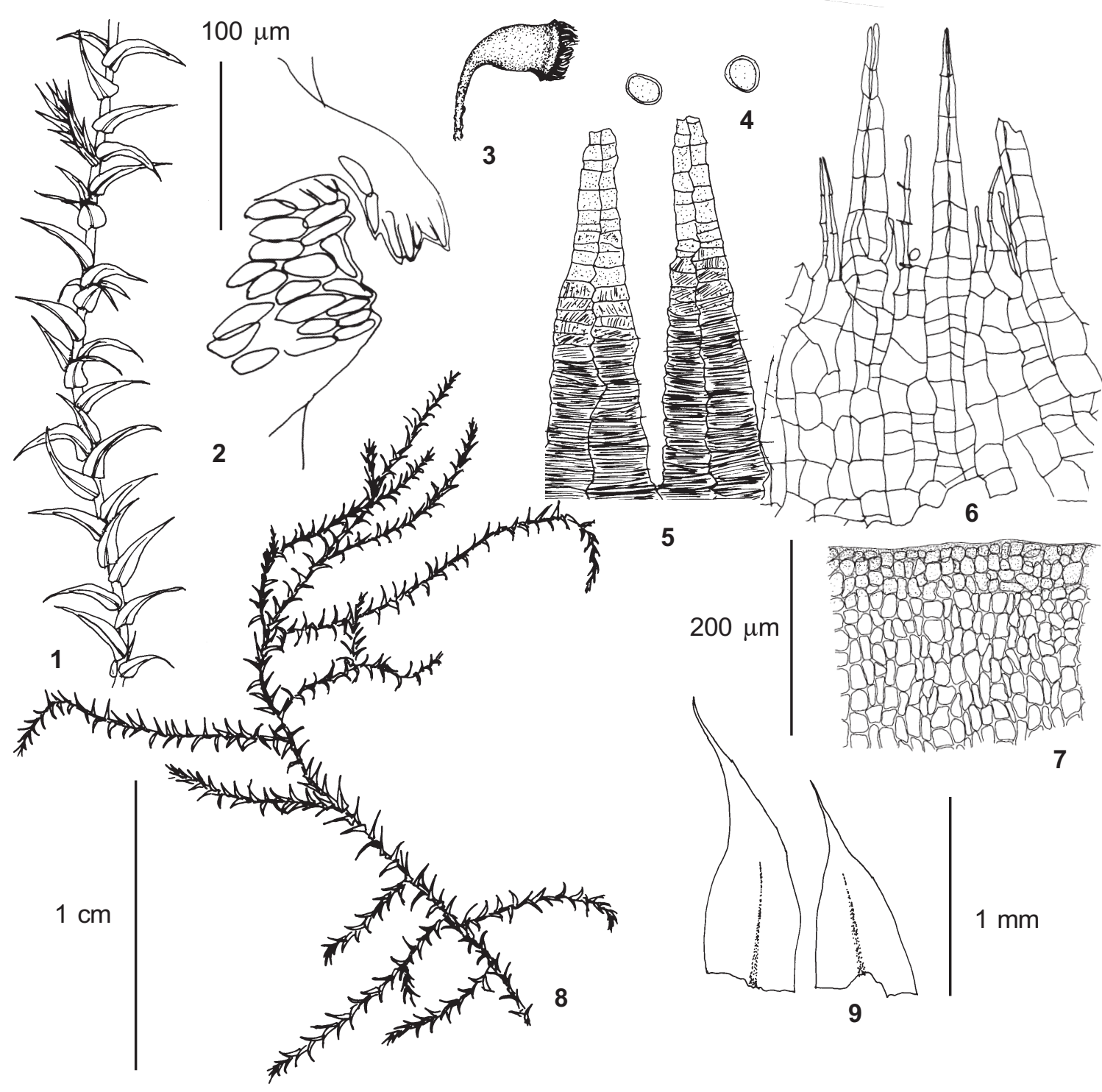

Fig. 38. Eurhynchium altaicum Ignatov sp. n. (from holotype: Keller, 16.VI.1910, H-BR): 1 - upper part of stem; 2 pseudoparaphyllia around branch initial; 3 - capsule; 4 - spores; 5 - part of exostome; 6 - part of endostome; 7 - exothecial cells; 8 - habit; 9 - perichaetial leaves. Scale bars: $1 \mathrm{~cm}$ for $8 ; 1 \mathrm{~mm}$ for $1,3,9 ; 200 \mu \mathrm{m}$ for 5-7; $100 \mu \mathrm{m}$ for 2, 4 .

Costa longa, folia decurrentia, seta scabra E. paelongo similis, sed differnt foliis caulinis et ramorum similitudine, foliis rigidis et suarrosis, decurrentia angusta, pseudoparaphyllis brevibus, statu autoico.

Holotype: "Altai, Distr. Smeinogorsk, pr. fl. Malaja Belaja, in abigno, 16.VI.1910 leg. B. Keller" (handwriting of Brotherus, who identified the specimen as Oxyrrhynchium praelongum (L.), H-BR, folder 3027!).

Plants medium-sized, yellow-green. Stem prostrate, remotely branched, branches to $14 \mathrm{~mm}$ long. Pseudoparaphyllia truncate-triangular. Stem leaves remote, spreading to squarrose, to $1.4 \times 0.75 \mathrm{~mm}$, ovate-triangular, gradually acuminate, widest at 1 ,
5-1/7 of leaf length; not plicate; at base very narrowly decurrent; costa reaching to nearly the apex, ca. $100 \mu \mathrm{m}$ wide at base, ending in stout tooth; margin serrulate throughout. Median laminal cells (15-)25-45 x 6-10 (4.5-8/1.5-2.0) $\mu \mathrm{m}$; towards base cells wider and shorter in several rows; in leaf corner cells wider, forming extensive alar group indistinctly delimited and reaching $1 / 2-1 / 3$ of distance to costa, sometimes alar group poorly differentiated. Leaves in distal parts of stem and branches smaller, in proximal parts of branches approaching stem leaves, with costa ending in spine. Autoicous. Perichaetial leaves gradually acuminate, with costa to about $1 / 3$ of leaf length. Seta strongly mammillose, 
$1.3 \mathrm{~cm}$. Capsule inclined, ca. $1.0 \mathrm{~mm}$ long. Peristome complete, endostome as high as exostome, segments narrowly perforated, cilia 2-3, much shorter than segments, nodose to shortly appendiculate. Operculum not seen. Calyptra smooth. Spores 18-20 $\mu \mathrm{m}$.

This species is very peculiar in its rigid, squarrose leaves, little differentiated stem and branch leaves, a costa that reaches to $0.9-0.95$ of leaf length, the autoicous sexual condition, and strongly mammillose seta. The size of the plants, the long costa, decurrent leaves and strongly rough seta agree with $E$. praelongum, but $E$. altaicum differs from this species in its (1) free or loose-pinnate branching with no clear differentiation between stem and branch leaves; (2) very rigidly squarrose leaves; (3) very narrow leaf decurrencies; (4) autoicous sexual condition; (5) short pseudoparaphyllia. The Japanese endemic E. squarrifolium Broth. was described as a species close to E. praelongum. However, I doubt that they are closely related. Eurhynchium squarrifolium has non-decurrent leaves, very narrow laminal cells, and a relatively short costa. Also contrary to its epithet, E. squarrifolium has not especially squarrose leaves, at least much less squarrose than those of E. altaicum.

Eurhynchium praelongum and some other related species are segregated into the genus Kindbergia by some authors (Robinson, 1967; Crum \& Anderson, 1981, etc.). This genus is said to be differentiated from Eurhynchium by its (1) strongly different shape of branch and stem leaves; (2) rather regularly pinnate branching; (3) stem leaves that have a broad base, strongly decurrent, and squarrose; (4) rather symmetric capsules. Buck (1988) disagreed with the recognition of Kindbergia as a separate genus, because even within E. praelongum there is a gradual transition to forms "which have an aspect like the other species in the genus Eurhynchium". Eurhynchium altaicum adds more problems with the separation of Kindbergia from Eurhynchium. In this species states of the main characters are different from those of Kindbergia (weakly heterophyllous, not very regular branching, short pseudoparaphyllia, not a broadly cordate base of stem leaves), but on the other hand, numerous similar states of the other characters indicate the high probability of its close affinity to E. praelongum.

Distribution: Eurhynchium altaicum is known only from the type collection.
Eurhynchium hians (Hedw.) Sande Lac., Ann. Mus. Bot. Lugduno-Batavum 2: 299. 1866.Fig. 39

Hypnum hians Hedw., Sp. Musc. Frond. 272. 70 f. 11-14. 1801.

Plants medium-sized, green to yellow-green, glossy. Stem prostrate, regularly pinnately branched, branches often complanate, to $6 \mathrm{~mm}$ long. Pseudoparaphyllia triangular, 1 at early stage. Axillary hairs 3-celled, all brownish, to $50 \times 17 \mu \mathrm{m}$, apical cell to $30 \mu \mathrm{m}$ long. Stem leaves erecto-patent to patent, to $1.1 \times 0.6 \mathrm{~mm}$, ovate to broadly ovate, acuminate, widest at $1 / 5-1 /$ 7 of leaf length; plane; at base shortly decurrent; costa reaching $0.6-0.8$ of leaf length, $30-40 \mu \mathrm{m}$ wide at base, ending in indistinct spine; margin serrate. Median laminal cells 30-65 x 5-7 (4-6/1.0-1.5) $\mu \mathrm{m}$; towards base cells wider and shorter in several rows; in leaf corner cells wider, forming small group, indistinctly delimited from the surrounding cells. Branch leaves patent, $0.9 \times 0.4 \mathrm{~mm}$,elliptic to ovate,shortly acute; costa ending in distinct spine. Gametangia and sporophyte not seen in Altai. [Dioicous. Seta mammillose. Operculum rostrate].

Distribution: Eurhynchium hians is very common in the hemiboreal and northern parts of the temperate zone of Europe, from Central Europe eastward to the basin of Volga River and Caucasus. It is a rather rare species in the Ural Mts. In Siberia it has a limited range in the mountains of South Siberia and neighboring lowlands, in the Russian Far East it is also confined to the hemiboreal and northern temperate zones. It is known from many provinces of China, but is absent in more xeric areas of NW China and Mongolia. In addition E. hians is known from Japan, Himalayas, North and East Africa, Macaronesia, North and Central America. In Altai E. hians is restricted to the lower elevations in regions with an especially mild climate. It grows in grasslands, in open Abies forests, in moderately disturbed places, on soil, and sometimes at bases of inclined tree trunks.

Specimens examined: Gorno-Altaisk $400 \mathrm{~m}$ (35/56); Kamga Bay 500 m (Zolotukhin 21.X.1989); Klyk Pass $600 \mathrm{~m}(0 / 646)$; Yailyu $440 \mathrm{~m}(0 / 644), 600 \mathrm{~m}(0 / 645)$.

Eurhynchium pulchellum (Hedw.) Jenn., Man. Mosses W. Pennsylvania: 350. 1913. Fig. 40

Hypnum pulchellum Hedw., Sp. Musc. Frond. 265. pl. 68: f. 1-4. 1801.

Plants small, yellow-green to yellow-brown. Stem prostrate, regularly to irregularly branched, branches distinctly julaceous to distinctly complanate, to 5 $\mathrm{mm}$ long. Pseudoparaphyllia obtuse-triangular. Axillary hairs 3-celled, to $50-60 \times 8-9 \mu \mathrm{m}$, apical cell to $30 \mu \mathrm{m}$ long. Stem leaves erect-spreading to spreading, $0.7-1.6 \times 0.4-0.8 \mathrm{~mm}$, ovate-triangular, acute to shortly acuminate, widest at $1 / 5-1 / 7$ of leaf length; 


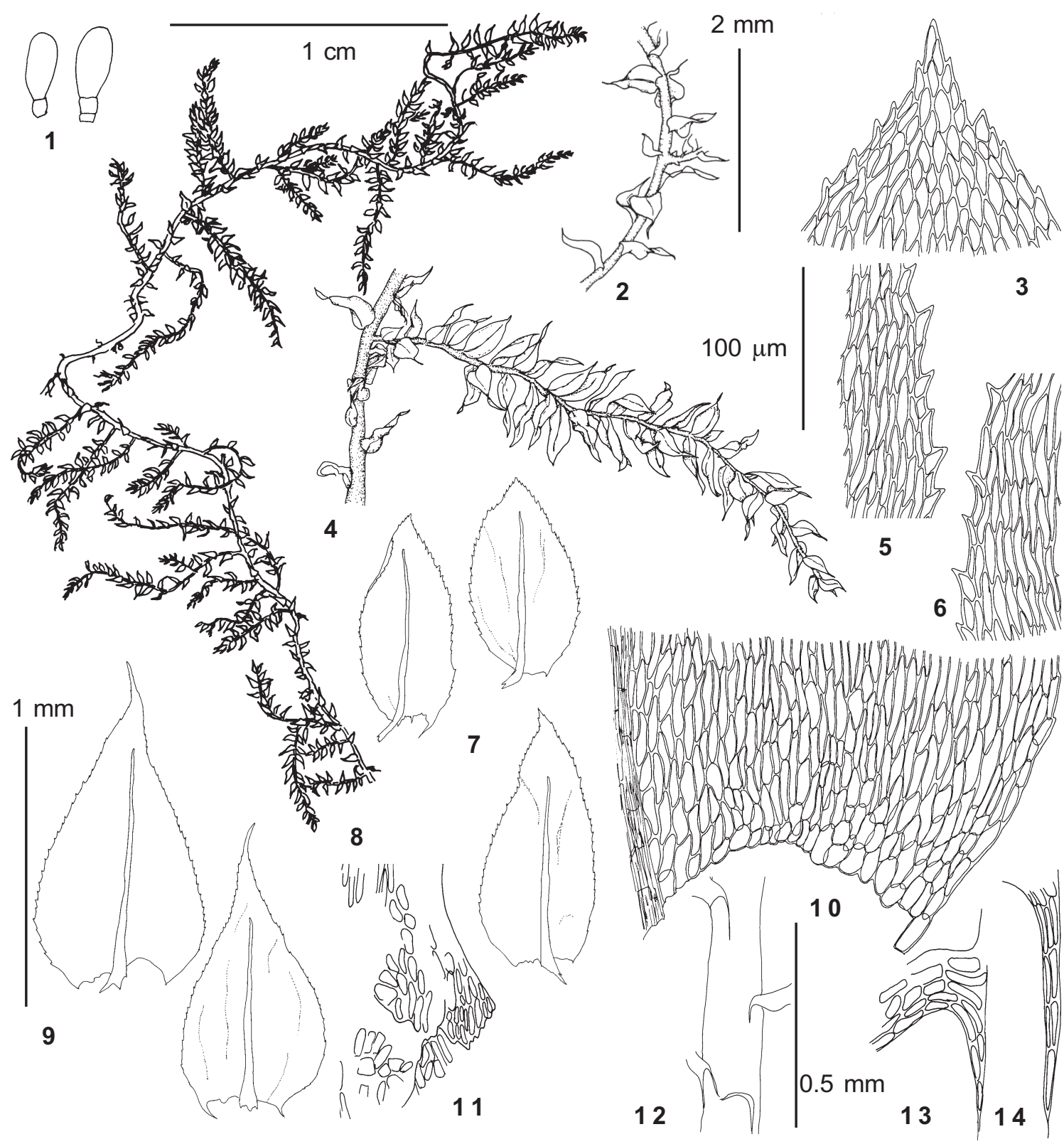

Fig. 39. Eurhynchium hians (Hedw.) Sande Lac. (from Ignatov 0/644): 1 - axillary hairs; 2 - part of stem; 3 upper laminal cells of branch leaf; 4 - part of stem with branch; 5 - median laminal cells of branch leaf; 6 - median laminal cells of stem leaf; 7 - branch leaves; 8 - habit; 9 - stem leaves; 10 - basal cells of stem leaf; 11 - branch initial with pseudoparaphyllia; 12 - stem leaf insertions; 13-14 - leaf decurrency. Scale bars: $1 \mathrm{~cm}$ for 8 ; $2 \mathrm{~mm}$ for 2 , $4 ; 1 \mathrm{~mm}$ for 7,$9 ; 0.5 \mathrm{~mm}$ for $12 ; 100 \mu \mathrm{m}$ for $1,3,5-6,10-11,13-14$.

slightly concave, not plicate; at base shortly or longly decurrent; costa reaching $0.5-0.8$ of leaf length, 20-35 $\mu \mathrm{m}$ wide at base, ending in short spine; margin serrulate throughout. Median laminal cells (30-) $40-60(-80) \times 4.5-6(3-4.5 / 1.5-2.0) \mu \mathrm{m}$; towards base cells of the same width or wider in 1-3 rows; in leaf corner subquadrate cells $(8-12 \mu \mathrm{m})$ forming \pm delimited concave group. Branch leaves ovate-triangular, narrowly obtuse; costa ending in stout tooth.
Phyllodioicous. Perichaetia on stem; dwarf males in leaf axils of the same plants (rarer in occurrence than perichaetia). Seta smooth, to $1 \mathrm{~cm}$ long. Operculum rostrate. Spores $17-23 \mu \mathrm{m}$.

Eurhynchium pulchellum is rather variable in Altai. Plants from xeric habitats are small, have julaceous shoots with small broadly obtuse leaves, with laminal cells of stem leaves 


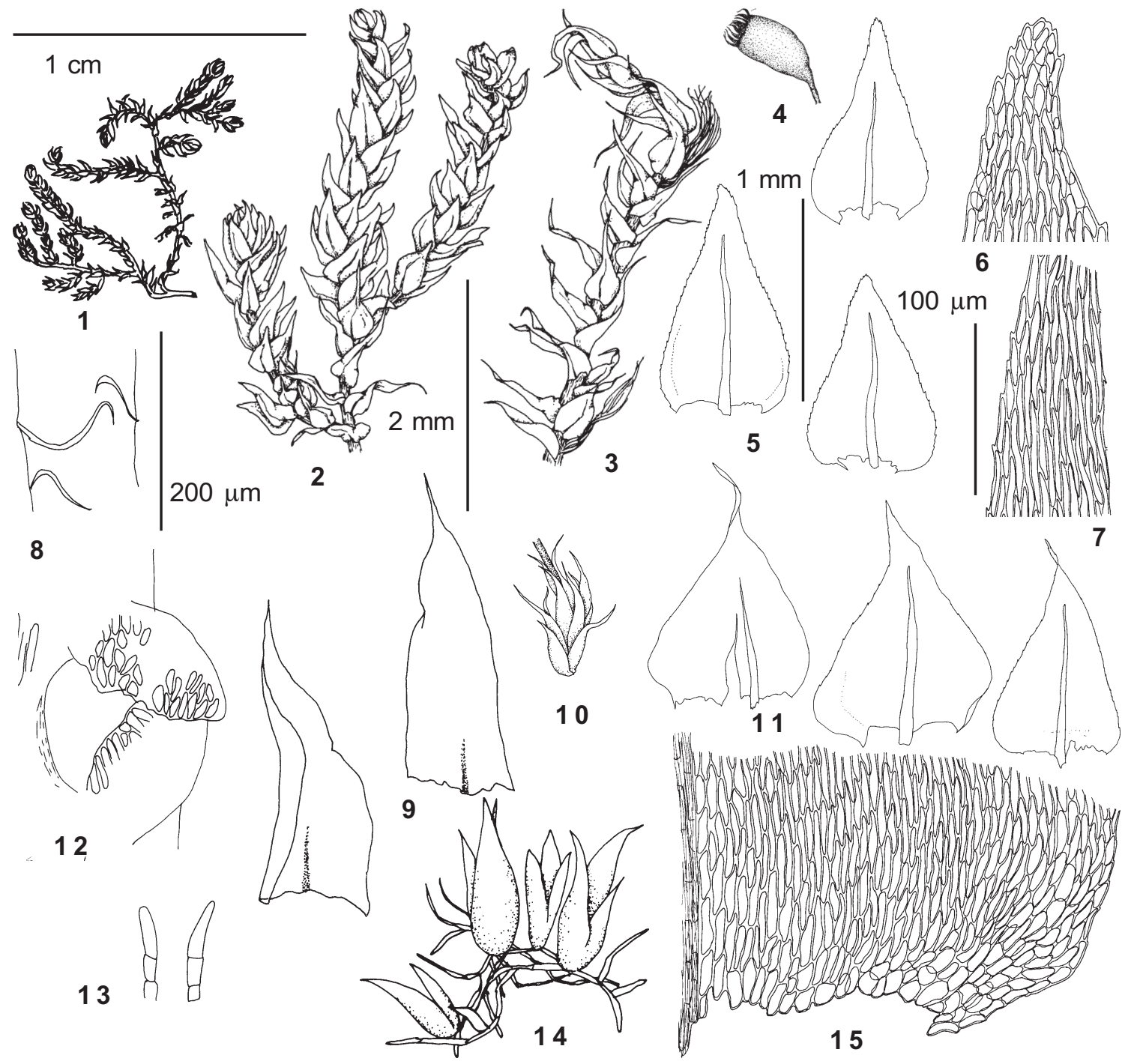

Fig. 40. Eurhynchium pulchellum (Hedw.) Jenn. (from Ignatov 0/1231): 1 - habit; 2 - stem with branches; 3 upper part of stem; 4 - capsule; 5 - branch leaves; 6 - upper laminal cells of branch leaf; 7 - median laminal cells of branch leaf; 8 - stem leaf insertions; 9 - perichaetial leaves; 10 - perichaetium; 11 - stem leaves 12 - branch initial with pseudoparaphyllia; 13 - axillary hairs; 14 - dwarf male plants; 15 - basal cells of stem leaf. Scale bars: $1 \mathrm{~cm}$ for 1; $2 \mathrm{~mm}$ for 2-4, 10; $1 \mathrm{~mm}$ for $5,9,11,14 ; 200 \mu \mathrm{m}$ for $8 ; 100 \mu \mathrm{m}$ for $6-7,12-13,15$.

around $40 \mu \mathrm{m}$ long. Plants from wet cliffs have long, creeping stems (to $5 \mathrm{~cm}$ and more) with regularly pinnate, strongly complanate branches, with laminal cells of stem leaves around 70 $\mu \mathrm{m}$. The stem leaves vary from acute or acuminate to narrowly obtuse.

Distribution: Widely distributed throughout most of the Holarctic, including the Arctic, boreal and north-temperate forests to mountain areas at low latitudes in Africa, Himalayas, South-East Asia. Reported also from South America. In Altai $E u^{-}$ rhynchium pulchellum is rather common in most areas, at all elevations. In the forest belt it grows mostly on eroded slopes and rock outcrops and sometimes on rotten wood. Above the tree-line E. pulchellum is more common in relatively xeric areas, among rocks and on tundro-steppe slopes on soil.

Specimens examined: Ayukol $1100 \mathrm{~m}(0 / 1231)$; Ayulyuyuzyuk Creek 2150 m (0/169); Bolshoye Istyube Creek $470 \mathrm{~m}(0 / 1226)$; Chulcha River, in middle course $1100 \mathrm{~m} \mathrm{(9/70);} \mathrm{Kaira} \mathrm{River,} 8 \mathrm{~km}$ upstream $1000 \mathrm{~m}$ (15/101); Kairu Creek, 16 km upstream $1400 \mathrm{~m}$ (14/ 37); Kairu Creek, 6 km upstream 900 m (15/150); Kairu Creek, 8 km upstream $1000 \mathrm{~m}(15 / 45 ; 15 / 52 ; 15 / 6$; 15/60; 15/83); Kairu-Bazhi Peak 2200 m (13/125); Kamga Creek, 10 km upstream 500 m (0/89); Kamga Creek, 8 km upstream $500 \mathrm{~m}(0 / 1228)$; Karakem River, $6 \mathrm{~km}$ upstream $1600 \mathrm{~m}(0 / 1227 ; 0 / 1230)$; Kayakkatu- 


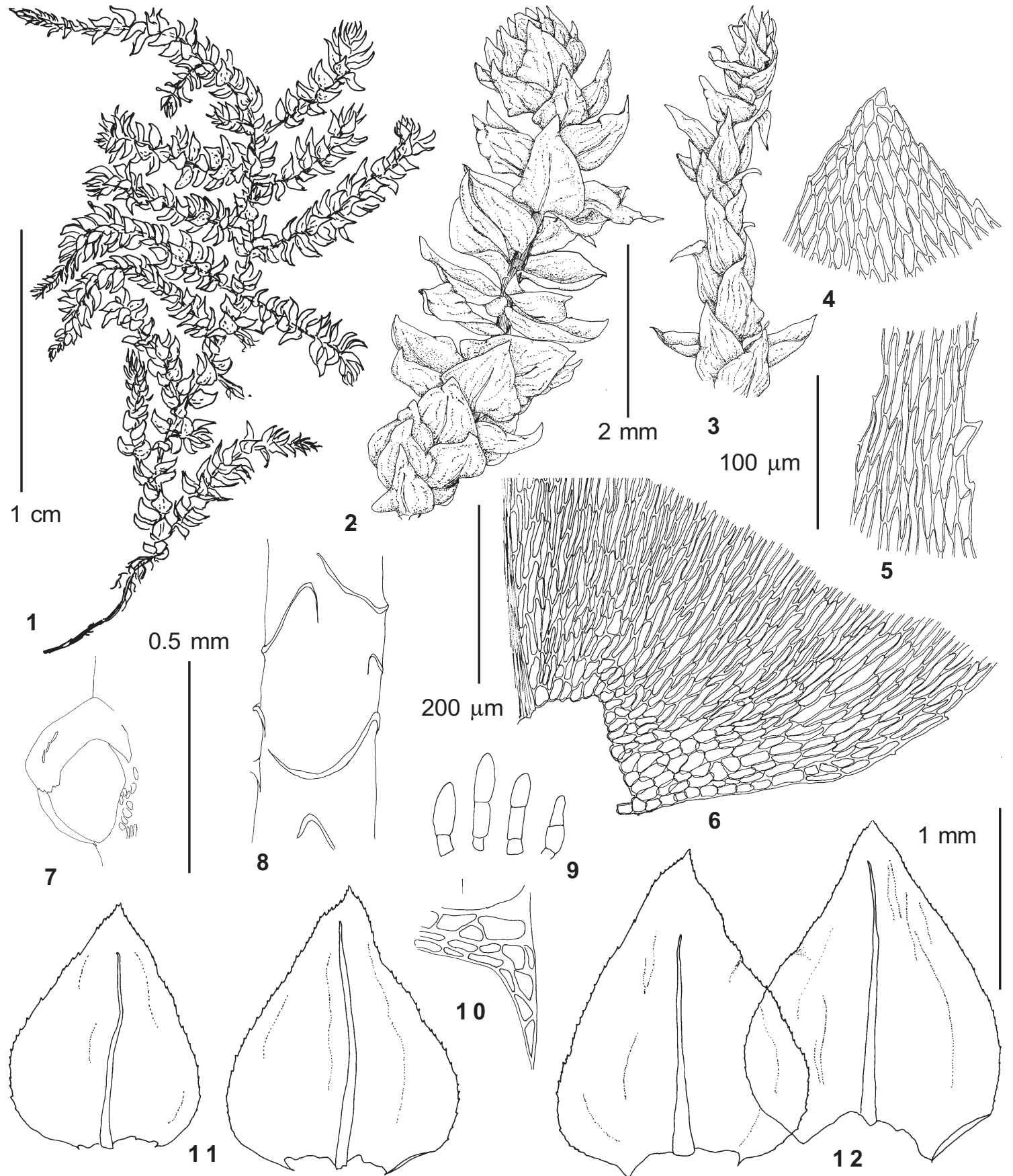

Fig. 41. Eurhynchium angustirete (Broth.) Kop. (from Ignatov 34/45): 1 - habit; 2 - upper part of branch; 3 upper part of stoloniferous stem; 4 - upper laminal cells of stem leaf; 5 - median laminal cells of stem leaf; 6 - basal cells of stem leaf; 7 - branch initial with pseudoparaphyllia; 8 - stem leaf insertions; 9 - axillary hairs; 10 - leaf decurrency; 11 - branch leaves; 12 - stem leaves. Scale bars: $1 \mathrm{~cm}$ for 1; $2 \mathrm{~mm}$ for 2-3; $1 \mathrm{~mm}$ for 11-12;0.5 mm for $8 ; 200 \mu \mathrm{m}$ for $6-7 ; 100 \mu \mathrm{m}$ for $4-5,9-10$.

yarykskij Creek $1800 \mathrm{~m}(8 / 286)$; Kobiguayuk Creek $2300 \mathrm{~m}(0 / 139) ;$ Kukol $1800 \mathrm{~m}(0 / 1229 ; 0 / 1278)$; Malyi Yaloman Creek, $7 \mathrm{~km}$ upstream $1000 \mathrm{~m}$ (25) 115); Pass between Bashkaus \& Pravyi Bogoyash 2900 $\mathrm{m}(36 / 322 ; 36 / 323 ; 36 / 324 \mathrm{a})$; Saluru Creek, in middle course $2050 \mathrm{~m}(36 / 289 \mathrm{a})$; Tabozhok Creek, $8 \mathrm{~km}$ upstream $2050 \mathrm{~m}(30 / 154)$; Tabozhok Peak $2350 \mathrm{~m}$ (31/150; 31/75), $2700 \mathrm{~m}(31 / 63)$; Yailyu $450 \mathrm{~m}(0 /$ 1277), $600 \mathrm{~m}(0 / 648)$.

Eurhynchium angustirete (Broth.) T.Kop., Memoranda Fauna Fl. Fenn. 43: 53. 1967. Fig. 41 
Brachythecium angustirete Broth., Rev. Bryol., n. s. 2: 11. 1929.

Plants robust, green to whitish-green, growing in thick mats due to arcuate stems and branches. Stem regularly branched, branches subjulaceous, to $10 \mathrm{~mm}$ long; partly stem and branches stoloniferous, partly abruptly blunt. Pseudoparaphyllia triangular. Axillary hairs 2-3-celled, all cells brownish, 40-70 × 11-13 $\mu \mathrm{m}$, apical cell to $45 \mu \mathrm{m}$ long. Stem leaves spreading, to $1.8 \times 1.2 \mathrm{~mm}$, broadly ovate, shortly acute, widest at $1 / 5-1 / 7$ of leaf length; concave, distinctly longitudinally plicate; at base shortly decurrent; costa reaching 0.65-0.8 of leaf length, $60-70 \mu \mathrm{m}$ wide at base; margin serrate throughout. Median laminal cells (25)40-70 x 5.5-7 (4-5.5/1.5-2.0) $\mu \mathrm{m}$, flexuose; in leaf corners wide and short cells (ca. $30 \times 20 \mu \mathrm{m})$ forming conspicuous group more or less distinctly delimited from surrounding cells. Branch leaves similar to stem leaves; costa ending in distinct tooth. Gametangia and sporophyte not seen in Altai. [Dioicous or phyllodioicous. Seta smooth. Operculum rostrate].

Distribution: Eurhynchium angustirete has an extensive continuous distribution in Europe, from Central European eastwards to the longitude of Moscow Province, in Caucasus, Altai and Western Sayans of South Siberia, China (many provinces), and Taiwan (type locality). A worldwide distribution map was published by Koponen \& Luo (1992). In Altai E. angustirete grows at lower elevations, in Abies and Pinus sibirica forests, on soil and occasionally at tree bases.

Specimens examined: Artybash $450 \mathrm{~m}(22 / 9)$; Ayukol $800 \mathrm{~m}(0 / 1224)$; Bolshoye Istyube Creek $470 \mathrm{~m}$ (18/130; 18/76); Chemal Creek, $3 \mathrm{~km}$ upstream $450 \mathrm{~m}$ (34/45); Derbogach 440 m (0/1222); Kamga Creek, 10 km upstream $580 \mathrm{~m}$ (0/1223); Maima $280 \mathrm{~m}$ (35/29); Teletzkoye Lake 450 m (470; Korotkov 21.IX.1958); Yailyu $450 \mathrm{~m}(0 / 1225)$.

\section{Platyhypnidium Fleisch.}

Fleischer (1923) segregated this genus for robust, aquatic broad-leaved plants. He considered it to be a member of Amblystegiaceae, and therefore provided no comparison with genera of the Brachytheciaceae. By having rigid, shortly acute leaves Platyhypnidium is similar to Eurhynchium, but the costa is not ending in a tooth, like in Rhynchostegium. Moreover Platyhypnidium is similar to the latter in its autoicous sexual condition. Thus, species of Platyhypnidium were for a long time included into either Eurhynchium or Rhynchostegium. To my mind, Platyhypnidium has enough special character states to be considered a good genus: (1) plants robust, rigid, growing sub- merged in or near streams; (2) perichaetial leaves with stout straigth acumen; (3) peristome teeth strongly incrassate, massive (see Ignatov \& al. 1998a). The genus includes about 6 species throughout the world, except in cold and some boreal areas.

Platyhypnidium riparioides (Hedw.) Dix., Rev. Bryol. Lichénol. 6: 111. 1933 [1934]. $\quad$ Fig. 42

Hypnum riparioides Hedw., Sp. Musc. Frond.242.1801.- Rhynchostegium riparioides (Hedw.) C. Jens., Cardot in Tourr., Bull. Soc. Bot. France 60: 231. 1913. - Eurhynchium riparioides (Hedw.) Rich.,Ann. Bryol.9: 135. 1936.

Plants robust, deep green to yellow-green. Stem irregularly or rarely regularly branched, branches subjulaceous, usually indistinctly differentiated from stem and mostly having indefinite growth. Pseudoparaphyllia truncate-triangular. Axillary hairs 4-5-celled, all brownish, 70-100 x 8-10 $\mu \mathrm{m}$, apical cell to $40 \mu \mathrm{m}$ long. Stem leaves erect-appressed, 1.6-2.4 x 1.1-1.4 mm, ovate to elliptic,often asymmetric,acute to shortly so,widest at 1/2-1/4 of leaf length; not plicate, somewhat twisted; practically non-decurrent; costa reaching 0.25-0.75 of leaf length, 70-100 $\mu \mathrm{m}$ wide at base, not ending in spine, sometimes forking; margin serrulate throughout. Median laminal cells 50-70(100) x 7-10 (5-8/1.5-2.0) $\mu \mathrm{m}$; towards base cells wider and shorter in several rows; in leaf corner cells wider, forming extensive pellucid alar group \pm well delimited (in some leaves, however, indistinct) and reaching $1 / 2-1 / 3$ of distance to costa. Branch leaves lanceolate, abruptly tapered into short often twisted acumen; costa not ending in spine. Autoicous. Perichaetial leaves with stout acumen, costa to about $1 / 4$ of leaf length. Seta smooth, to $1 \mathrm{~cm}$ high. Capsule $1.5 \mathrm{~mm}$ long, inclined. Operculum rostrate. Spores $10 \mu \mathrm{m}$.

This speceis is easy to recognize by its robust aquatic plants, typically very weakly branched stems, leaves ovate, not plicate, tending to be twisted, with margin sharply serrate nearly to the base.

Distribution: Widely distributed in temperate regions of the Holarctic (rarer in boreal zone), but with extensive gaps in regions with acid soils and rocks. In Altai it grows in running water of streams and creeks, and on wet rocks beside waterfalls, being confined to the lowermost elevations near Teleztkoye Lake and the middle range of Katun River.

Specimens examined: Bolshoye Istyube Creek $470 \mathrm{~m}$ $(0 / 650 ; 18 / 34)$; Chemal Creek, $3 \mathrm{~km}$ upstream $450 \mathrm{~m}$ (34/149); Elekmonar $400 \mathrm{~m}$ (Zerov 21.VIII.1940); Kishte $440 \mathrm{~m}$ (Zolotukhin 11.VII.1988); Kumzir $450 \mathrm{~m}$ (20/12); Ok-Porok Creek, 1.5 km upstream $470 \mathrm{~m}(2 / 23 ; 2 / 52)$; Yailyu $450 \mathrm{~m}(1 / 35)$; Yurga $450 \mathrm{~m}(21 / 10)$. 


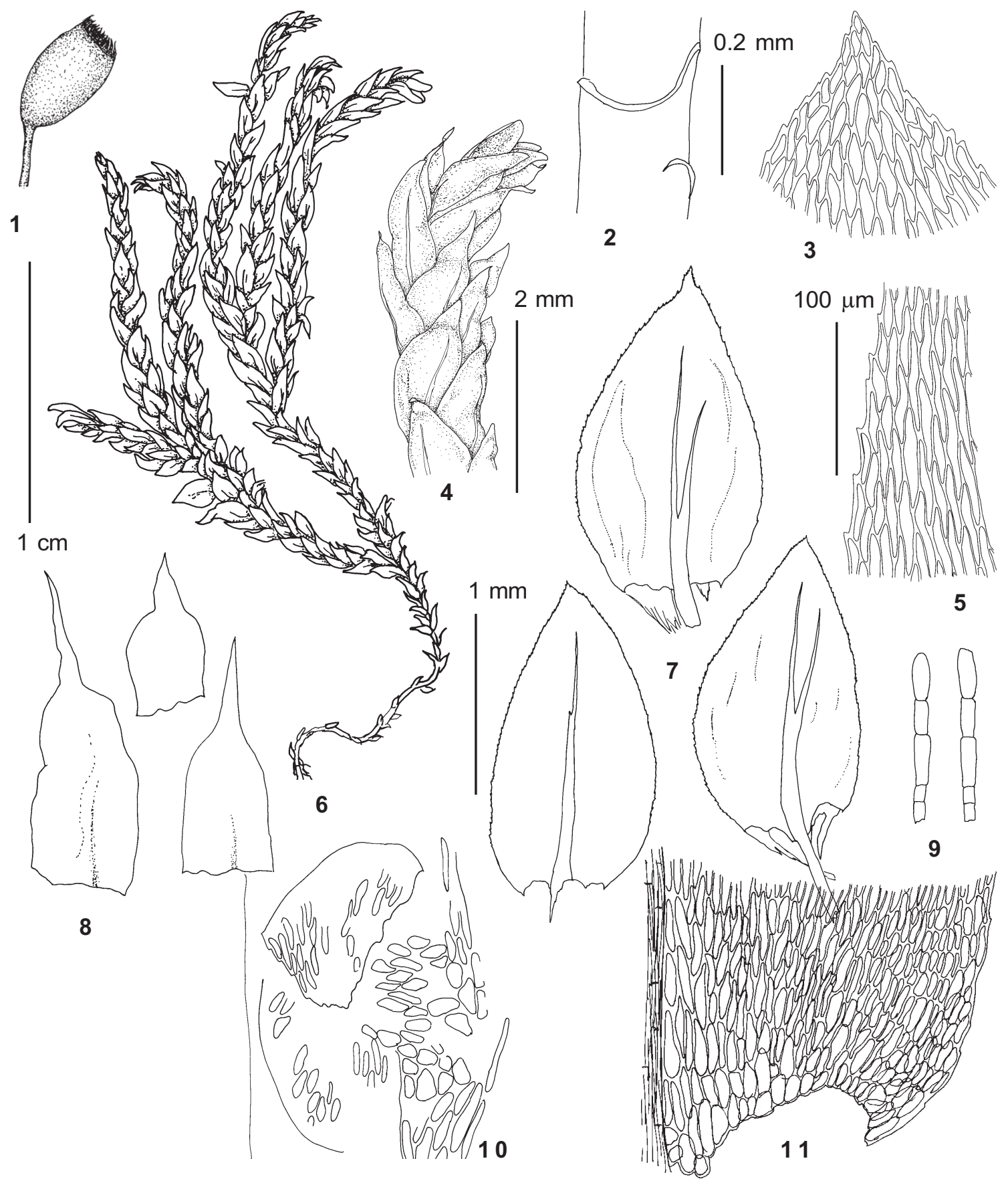

Fig. 42. Platyhypnidium riparioides (Hedw.) Dix. (from Ignatov 1/35): 1 - capsule; 2 - stem leaf insertions; 3 upper laminal cells of stem leaf; 4 - upper part of stem; 5 - median laminal cells of stem leaf; 6 - habit; 7 - stem leaves; 8 - perichaetial leaves; 9 - axillary hairs; 10 - branch initial with pseudoparaphyllia; 11 - basal cells of stem leaf. Scale bars: $1 \mathrm{~cm}$ for $6 ; 2 \mathrm{~mm}$ for 1,$4 ; 1 \mathrm{~mm}$ for $7-8 ; 0.2 \mathrm{~mm}$ for $2 ; 100 \mu \mathrm{m}$ for 3, 5, 9-11.

Scleropodiopsis Ignatov gen. nov.

$\mathrm{Ab}$ omnibus reliquis Brachytheciaceis foliis valde obtusis vel apiculatis et cellulis foliorum laxissimis differt.
Type: Scleropodiopsis laxiretis Ignatov

This genus differs from all other Brachytheciaceae with obtuse or slightly apiculate leaves by the very lax areolation of leaf. 

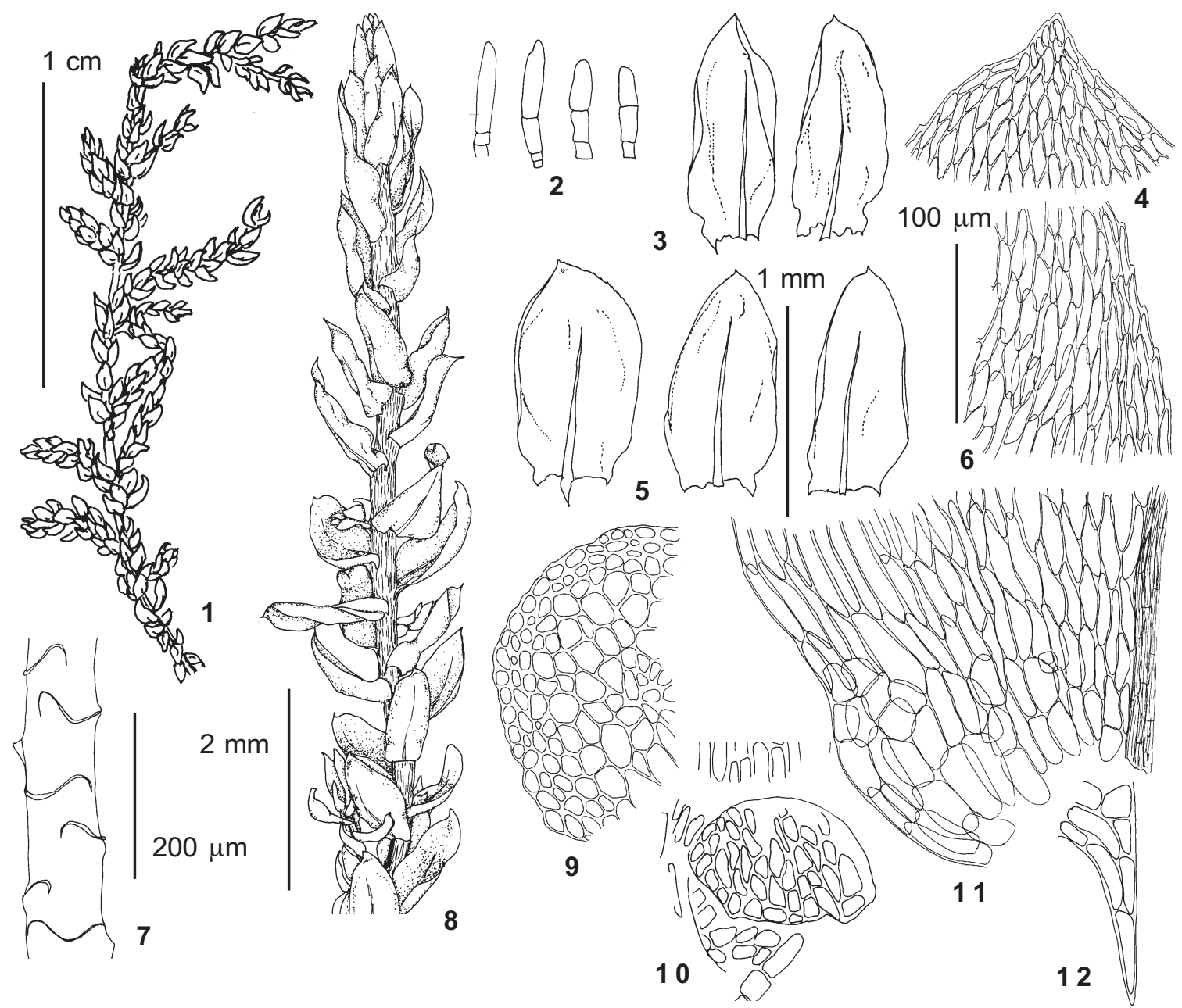

Fig. 43. Scleropodiopsis laxiretis Ignatov (from holotype, Ignatov 26/113): 1 - habit; 2 - axillary hairs; 3 - branch leaves; 4 - upper laminal cells of stem leaf; 5 - stem leaves; 6 - median laminal cells of stem leaf; 7 - stem leaf insertions; 8 - upper part of stem; 9 - stem transverse section; 10 - branch initial with pseudoparaphyllia; 11 - basal cells of stem leaf; 12 - leaf decurrency. Scale bars: $1 \mathrm{~cm}$ for $1 ; 2 \mathrm{~mm}$ for $8 ; 1 \mathrm{~mm}$ for 3, 5; $200 \mu \mathrm{m}$ for 7; $100 \mu \mathrm{m}$ for 2, 4, 6, 9-12.

Scleropodiopsis laxiretis Ignatov sp. nov.

Fig. 43

Planta mediocris, viridis. Caulis pinnate ramosus, rami julacei, ad $6 \mathrm{~mm}$ longi. Folia caulina late-ovata, obtusa vel paulo apiculata, latissima ad $1 / 3$ longitudinis, distincte concava, parce plicata, versus basin breviter decurrentia, costa ad 0.65-0.75 longitudinis laminae, basi $40 \mu \mathrm{m}$ lata, margines serrulati. Cellulae laminorum medianae 25-55 x 10-12 (9-11/1.0) $\mu \mathrm{m}$, basin versus latiores, alares breviter rectangulares, ad $20 \mu \mathrm{m}$ lato, aggregationes subquatratae formantes.

Holotype: Russia, Altai Mts., $51^{\circ} 29^{\prime} \mathrm{N}-86^{\circ} 26^{\prime} \mathrm{E}$, Karakol Lakes, $1900 \mathrm{~m}$, wet rocks in subalpine zone. $2 \mathrm{Au}-$ gust 1991, leg. M. Ignatov \& E. Ignatova, 26/113 (MHA).

Plants medium-sized, green. Stem pinnate branched, branches julaceous, to $6 \mathrm{~mm}$ long. Pseudoparaphyllia orbicular to triangular. Axillary hairs 50-70 x $12 \mu \mathrm{m}$, apical cell to $35 \mu \mathrm{m}$ long. Stem leaves 1.0 x $0.6 \mathrm{~mm}$, broadly ovate, obtuse to slightly apiculate, widest close to $1 / 3$ of leaf length; strongly concave, indistinctly plicate; at base shortly decurrent; costa reaching $0.65-0.75$ of leaf length, $40 \mu \mathrm{m}$ wide at base; margin serrulate. Median laminal cells 25-55 x 10-12 (9-11/1.0) $\mu \mathrm{m}$; towards base wider in several rows; in leaf corner short-rectangular cells (up to $20 \mu \mathrm{m}$ wide) forming square alar group \pm well delimited and reaching ca. $1 / 2$ of distance to costa. Branch leaves narrower; costa not ending in spine. Gametangia and sporophyte not seen.

This species was collected only once, but I do not hesitate to describe it as a new species and even new genus, because of its lax areolation which is exeptional in Brachytheciaceae. Median laminal cells in this family are usually $6-9 \mu \mathrm{m}$ wide. The cells of $10-12 \mu \mathrm{m}$ wide are known in some robust expressions of Brachythecium reflexum 
(cf. Fig. 26) or B. glaciale, and in Rhynchostegium rotundifolium (Brid.) B. S. G. median laminal cells are to $12-15 \mu \mathrm{m}$ wide. However, these species have a more incrassate cell walls and acute to acuminate leaves, and cannot be considered as a relative Scleropodiopsis.

Another diagnostic character of $S$. laxiretis is concave obtuse to slightly apiculate leaves. Similar leaves are known in the Brachytheciaceae in Scleropodium, Pseudoscleropodium and Brachythecium ornellanum. However, all these taxa have narrow and \pm flexuose laminal cells, contrasting with the very lax areolation in Scleropodiopsis.

Also, Scleropodium has a rather southern distribution and also this genus itself may not be monophyletic (cf. Ignatov \& al., 1998a). Brachythecium (Scleropodium) ornellanum has a habit somewhat similar to that of Scleropodiopsis, but it differs in the following: (1) narrow laminal cells; (2) ovate-triangular leaves; (3) longly decurrent leaves (cf. Figs. 23, 43).

The general appearance of Scleropodiopsis, its thin-walled laminal cells and well inflated alar cells are somewhat similar to those of $\mathrm{Cal}$ liergon. However, the pseudoparaphyllia are typical for Brachytheciaceae (cf. Ignatov, 1998) and some other characters also indicate that Calliergon is not closely related (Brachythecium-gloss on plants; very short leaf decurrencies).

DOUBTFUL AND ERRONEOUS RECORDS

Brachythecium glareosum (Spruce) B. S. G. - reported by Bardunov (1974); one of his specimens (Chulyshman River mouth, 6.VII. 1966 Bardunov, IRK) belong to B. rotaeanum.

B. campestre (C. Muell.) B. S. G. - reported by Godvinsky (1966), but his collections have not been found. Also reported by Gudoshnikov (1986), but there are no specimens in herbarium of Tomsk University.

Eurhynchium praelongum (Hedw.) B. S. G. reported by Krylov (1925). Some of his specimens in $\mathrm{H}$ belong to $E$. hians, one - to E. altaicum. Also reported by Gudoshnikov (1986), but there are no specimens in herbarium of Tomsk University.

E. schleicheri (Hedw. f.) Lor. - reported by Godvinsky (1966), but his collections have not been found.

E. striatum (Hedw.) B. S. G. - reported by Krylov (1925) and Bardunov (1974). All so named specimens from Altai belong to E. angustirete (in $\mathrm{H}$ and IRK).

\section{AKNOWLEDGEMENT}

I'm very grateful to N. I. Zolotukhin and L. V. Bardunov making to my disposal their collections from Altai, to E. D. Lapshina for information about collections in Tomsk Herbarium, to curators of $\mathrm{H}$ and LE for loans of specimens, and Timo Koponen for support of my work in H-BR. Also I thank L. Hedenäs for careful reading and numerous suggestions on the manuscript,A. K.Skvortsov for translation into Latin, and E. A. Ignatova for drawning of illustrations and other assistance. This work was partially supported by the Russian Foundation for Fundamental Researches, 96-04-48033.

\section{LETERATURE CITED}

[ABRAMOVA, A. L., L. I.SAVICZ-LJUBITSKAYA \& Z. N.SMIRNOVA] АБРАМОВА, А.Л., Л.И.САВИЧЛЮБИЦКАЯ, 3.Н.СМИРНОВА 1961. Определитель листостебельных мхов Арктики СССР. - [Handbook of mosses of Arctic of the USSR] M.-Л., Изд. АН СССР [Moscow-Leningrad, Izd. Akad. Nauk SSSR], 716.

AFONINA, O. M. \& I. V. CZERNYADJEVA 1995. Mosses of the Russian Arctic: check-list and bibliography. Arctoa 5: 99-142.

AMMAN, J. 1918. Flore des mousses de la Suisse. Deuxičme partie. Lausanne, 215.

[BARDUNOV, L.V.] БАРДУНОВ, Л.В 1969. Определитель листостебельных мхов Центральной Сибири. [Handbook of mosses of Central Siberia] Л., Наука [Leningrad, Nauka], 319.

[BARDUNOV, L. V.] БАРДУНОВ, Л. В. 1974. Листостебельные мхи Алтая и Саян - [Mosses of the Altai and Sayan Mts.]. Новосибирск, Наука [Novosibirsk, Nauka], 168.

[BARDUNOV, L.V.] БАРДУНОВ, Л.В 1992. Очерк бриофлоры Сибири. - [An overview of the Siberian bryoflora] Новосибирск, Наука [Novosibirsk, Nauka], 97.
BROTHERUS, V. F. 1925. Musci. - In: Engler, A. \& Pranl, K (eds.), Die Natbrlichen Pflanzenfamilien, ed. 2, 11: 1-522. W. Engelmann, Leipzig.

BRUCH, PH., W. PH. SCHIMPER \& TH. HÜMBEL 185155. Bryologia Europaea seu genera muscorum Europaeorum. T. 5-6. Stuttgartiae.

BUCK, W. R. 1988. Taxonomic and nomenclatural notes on West Indian Amblystegiaceae and Brachytheciaceae. - Beih. Nova Hedwigia 90: 337-343.

CRUM, H. \& L. E. ANDERSON 1981. Mosses of the Eastern North America. I-II. New-York, Columbia Univ. Press, 1328.

DÜLL, R. 1985. Distribution of the European and Macaronesian mosses (Bryophytina). 1. - Bryol. Beitr. 4: 1-109.

DÜLL, R. 1994. Deutschlands Moose. Teil 3. IDH, Bad Münstereifal. 256.

FLEISCHER, M. 1923: Die Musci der Flora von Buitenzorg, Bd. 4. E. J. Brill., Leiden: 1105-1729.

GEISSLER, P. 1984. Notulae bryofloristicae Helveticae.Candollea 39: 641-646.

[GODVINSKY, М. I.] ГОДВИНСКИЙ, М. И. 1966. 
Листостебельные мхи прибрежий Рахмановского oзepa. - [Mosses of the surroundings of Rakhmanovskoye Lake] Бom. мam. uнст. бот. АН Каз CCP [Bot. Mat. Inst. Bot. Akad. Nauk. KazakhSSR] 4: 140-154.

GROUT, A. J. 1898. A revision of the North American Isotheciaceae and Brachythecia. - Mem. Torr. Bot. Club 6: $131-210$.

[GUDOSHNIKOV, S. V.] ГУ ДОШНИКОВ, C. В. 1986. Флора листостебельных мхов черневого подпояса Южных гор Сибири и проблема происхождения черневой тайги. - [Flora of mosses of czernevaya subzone of mountains of South Siberia and the origin of czernevaya taiga] Томск, Изд. Томск. ун-та [Tomsk, Izd. Tomsk. Univ.], 190.

HEDENÄS, L. 1995. On the identity of Brachythecium campestre (C. Müll.) B. S. \& G. in Sweden, Norway and Finland. - Lindbergia 20: 94-101.

HEDENÄS, L. 1996. Taxonomic notes on Brachythecium erythrorrhizon B. S. \& G., based mainly on studies of Swedish material. - Lindbergia 21: 21-25.

IGNATOV, M.S. 1992. The relationships of moss flora of Altai Mts. - Bryobrothera 1: 63-72.

IGNATOV, M. S. 1994. Bryophytes of Altai Mountains. I. Study area and history of its bryological exploration. Arctoa 3: 13-27.

IGNATOV, M. S. 1998. On the pseudoparaphyllia in Brachytheciaceae and Meteoriaceae. - Ann. Bot. Fennici 146 (in press).

IGNATOV, M. S. \& O. M.AFONINA (eds.) 1992. Checklist of the mosses of the former USSR. - Arctoa 1: 1-86.

IGNATOV, M. S. \& T. KOPONEN 1996. On the taxonomy of some East Asian Brachythecium (Brachytheciaceae, Musci). - Ann. Bot. Fennici 33: 285-301.

IGNATOV, M. S., H. ROBINSON \& E. A. IGNATOVA 1998a. Studies on the exostome of Brachytheciaceae (Musci). - Arctoa 7: 000-000.

IGNATOV, M. S., KOPONEN, T. \& NORRIS, D. H. 1998b. Bryophyte folra of Huon Peninsula, Papua New Guinea. 000. Brachytheciaceae. - Acta Bot. Fennici: 000-000.

IRELAND, R. R., G. R. BRASSARD, W. B. SCHOFIELD \& D. H. VITT 1987. Check-list of the mosses of Canada. II. - Lindbergia 13: 1-62.

KARTTUNEN, K. 1990. Nomenclatural and taxonomic notes on Cirriphyllum (Brachytheciaceae,Bryophyta).- Taxon 39(2): 312-320.

KOPONEN, T. 1987. Notes on Chinese Eurhynchium (Brachytheciaceae). - Mem. New York Bot. Gard. 45: 509-514.

KOPONEN, T. \& J.-X. LUO 1992. Moss flora of Wo-long Nature Reserve, Sichuan Province, China. - Bryobrothera 1: 161-175.

[KRYLOV, Р.] КРЫЛОВ, П. 1925. Материалы к флоре споровых растений Алтая и Томской губернии. [Contributions to the flora of spore plants of Altai and Tomsk Province]. Изв. Томск. Гос. Ун-та [Izv. Tотsk. Gos. Univ.] 75: 1-48.

LINDBERG, S. O. 1879. Musci Scandinavici in systemate novo naturali. Upsaliae, 50.

LIMPRICHT, K. G. 1896. Die Laubmoose. - In: L. Rabenhorst's Kryptogamen-flora von Deutschland, Oesterreich und der Schweiz. 4 Bd. 3 Abt. Leipzig,E. Kummer.
LOESKE, L. 1910. Studien zur vergleichenden Morphologie und der phylogenetischen Systematik der Laubmoose. Berlin, Max Lande. 224.

McFARLAND, K. D. 1994. Rhynchostegium. - In: Sharp, A. J., H. Crum \& P. M. Eckel, The moss flora of Mexico, New York Botanical Garden, NY: 932-941.

MOLENDO, L. 1875. Aufzählung der Laubmoose Bayerns. - Ber. Naturhist. Ver. Passau 10: 1-278.

MÖNKENMAYER, W. 1927. Die Laubmoose Europas (4: Andreaeales-Bryales). - In: L. Rabenhorst's Kryptogamen-flora von Deutschland, Oesterreich und der Schweiz. 4 Bd. Leipzig,Ergänzungsband, 960.

[MULDiYAROV, E. Ya.] МУльдИЯРОВ, Е. Я. 1990. Определитель листостебельных мхов Томской области. - [Handbook of mosses of Tomsk region] Томск, Изд. томск. унив. [Tomsk, Izd. Tomsk. Univ.], 208.

NISHIMURA, N. \& M. HIGUCHI 1993. Check-list of mosses of Pakistan. - Cryptogamic flora of Pakistan (Tokyo, National Science Museum) 2: 275-299.

NOGUCHI, A. 1991. Illustrated flora of Japan, pt. 4. Nichinan, Hattori Bo. Lab.: 743-1012.

NYHOLM, E. 1965. Illustrated Moss flora of Fennoscandia. II. Musci. Fasc. 5. Gleerups, Lund: 407-647.

PIIPPO, S. 1983. On the taxonomy, nomenclature and distribution of Brachythecium starkei (Brachytheciaceae, Musci) and related taxa. - Ann. Bot. Fenn. 20: 339-349.

PIIPPO, S. 1984. Suomen Brachythecium-lajien (Brachytheciaceae, Musci) määrittämisestä. - Mem. Soc. Fauna Flora Fennica 60: 45-53.

ROBINSON, H. 1962. Generic revisions of North American Brachytheciaceae. - Bryologist 65: 73-146.

ROBINSON, H. 1967 . Preliminary studies on the bryophytes of Columbia. - Bryologist 70(1): 1-61.

ROBINSON, H. 1987. Notes on generic concepts in the Brachytheciaceae and the new genus Steerecleus. - Mem. New York Bot. Garden. 45: 678-681.

[SCHLJAKOV, R. N.] ШЛЯКОВ, Р. Н. 1952. Новинки для бриофлоры CCCP. - [News for bryoflora of USSR] Бот. матер. Omд. cnop. pacm. Бот. ин-m AH CCCP [Botanicheskie Materialy Otd. Spor. Rast. Bot. Inst. Akad. Nauk SSSR] 8: 213-223.

TAKAKI, N. 1955a. Researches on the Brachytheciaceae of Japan and its adjacent areas. I. - J. Hattori Bot. Lab., 14: 1-28.

TAKAKI, N. 1955b. Researches on the Brachytheciaceae of Japan and its adjacent areas. II. - J. Hattori Bot. Lab., 15: 1-69.

TAKAKI, N. 1956. Researches on the Brachytheciaceae of Japan and its adjacent areas. III. - J. Hattori Bot. Lab., 16: 1-71.

WARNSTORF, C. 1906. Kryptogamenflora der Mark Brandenburg und angrenzender Gebiete, 2. Leipzig, Verlag von Gebrueder Borntraeger, 1160.

WIGH, K. 1974. The European genera of the family Brachytheciaceae (Bryophyta) and chromosome numbers published in te genus Brachythecium. - Bot. Notis. 127(1): 89-103.

WIGH, K. 1975. Scandinavian species of the genus Brachythecium (Bryophyta). II. Morphology, taxonomy and cytology in the B. rutabulum-B. rivulare complex. - Bot. Notis. 128(4): 476-496. 